\title{
WestVirginiaUniversity
}

THE RESEARCH REPOSITORY @ WVU

Graduate Theses, Dissertations, and Problem Reports

2016

\section{Behavior of Concrete Members Reinforced with Basalt FRP}

Mariam Albaghli

Follow this and additional works at: https://researchrepository.wvu.edu/etd

\section{Recommended Citation}

Albaghli, Mariam, "Behavior of Concrete Members Reinforced with Basalt FRP" (2016). Graduate Theses, Dissertations, and Problem Reports. 5049.

https://researchrepository.wvu.edu/etd/5049

This Thesis is protected by copyright and/or related rights. It has been brought to you by the The Research Repository @ WVU with permission from the rights-holder(s). You are free to use this Thesis in any way that is permitted by the copyright and related rights legislation that applies to your use. For other uses you must obtain permission from the rights-holder(s) directly, unless additional rights are indicated by a Creative Commons license in the record and/ or on the work itself. This Thesis has been accepted for inclusion in WVU Graduate Theses, Dissertations, and Problem Reports collection by an authorized administrator of The Research Repository @ WVU. For more information, please contact researchrepository@mail.wvu.edu. 


\title{
Behavior of Concrete Members Reinforced with Basalt FRP
}

\author{
Mariam Albaghli
}

Thesis submitted to the

Benjamin M. Statler College of Engineering and Mineral Resources at

West Virginia University in

partial fulfillment of the requirements for the degree of

Master of Science in

Civil Engineering

P.V. Vijay, Ph.D., PE Chair

Radhey Sharma, Ph.D.

Yoojung Yoon, Ph.D.

Department of Civil and Environmental Engineering

Morgantown, West Virginia

2016

Keywords: Basalt, FRP, Bar, Wrap, Fabric, Concrete Cylinder, Concrete Beam, Reinforcement, Stiffness, Crack Width, Deflection, Ultimate Load 


\section{Abstract \\ Behavior of Concrete Members Reinforced with Basalt FRP}

\section{Mariam Albaghli}

In the last decade, FRP composites in the form of internal and external reinforcement are being increasingly employed for construction and rehabilitation of structures. Glass and carbon fibers were the main types of fibers used in these composites and basalt fibers are emerging as alternative forms of reinforcement. Basalt fibers have high strength, stiffness, and corrosion resistance that are typical of composites. Composites are less expensive than carbon fibers and have better performance than E-glass fibers. The main objective of this research is to evaluate and determine the performance of concrete members reinforced with basalt Fiber Reinforced Polymer (BFRP). This research investigates the mechanical properties of basalt FRP bars in tension, compression, shear and bond. Concrete beams reinforced with BFRP bars (\#4 and \#5) and external BFRP fabrics were tested in bending. It was noted that the use of BFRP in concrete beams increased their bending capacity along with a reduction in the deflection and crack-width. Additionally, confinement related increased in strength and stiffness due to BFRP wrapping on concrete cylinders were investigated. The per layer increase in strength due to a layer of BFRP wrapping was up to $42 \%$. Theoretical values and experimental results were found to correlate reasonably well for cylinders and beams reinforced with BFRP. Additional testing and research are recommended with expanded parameters to develop refined deflection and crack-width models with due consideration to the BFRP stress, strain and bond-values. 


\section{Acknowledgments}

I would like to take this opportunity to thank all people who helped me throughout the period of my master's degree study and research. Special thanks for my advisor and professor, Dr. Vijay, who offered great and valuable suggestions. I am sincerely thankful for his patience and time during my research work. Also, I would like to thank my committee, Dr. Radhey Sharma and Dr. Yoojung Yoon, for being part of my research work.

My sincere thanks to Jerry Nestor and David Turner at West Virginia University who helped me in the laboratory. Without their help, I would not be able complete my tests. I am thankful to all my colleagues who helped me throughout my research work; Piyush Soti, Krishna Tulasi, Venkat Dheeraj, Dana Dashti, Luis Parra, and Jonas Kavi. I would like to thank my friends who have been incredibly supportive to me.

I would like to thank Don Smith and Bill Flores from "Raw Energy Materials Corp." for providing basalt FRP material.

I am extremely thankful for my family and my husband for their support, without them I wouldn't complete my degree.

Finally, I would like to thank my country, Kuwait, for giving me the opportunity to get my scholarship to study at the West Virginia University and completing my master's degree. 


\section{Table of Content}

1 INTRODUCTION

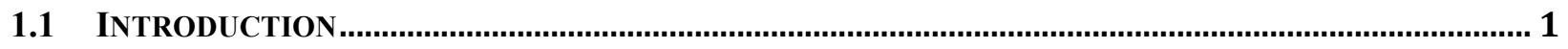

1.2 OBJECTIVES

1.3 SCOPE

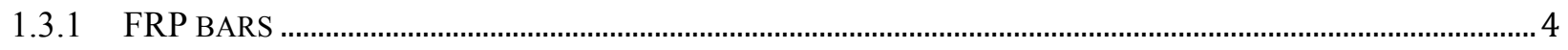

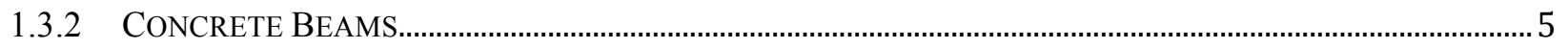

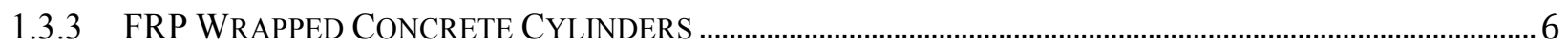

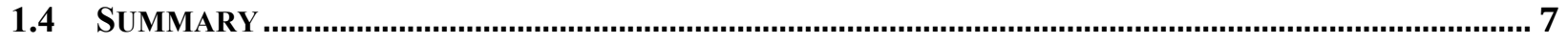

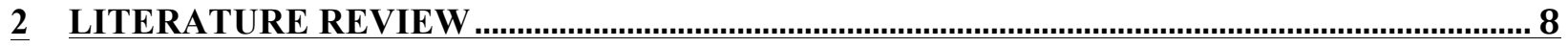

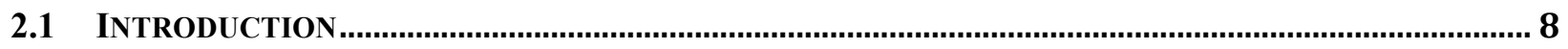

2.2 BASALT

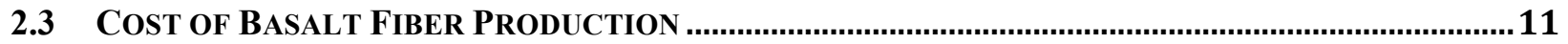

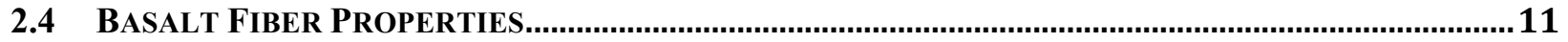

2.5 BFRP BAR

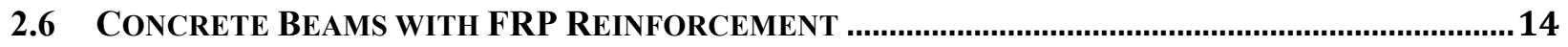

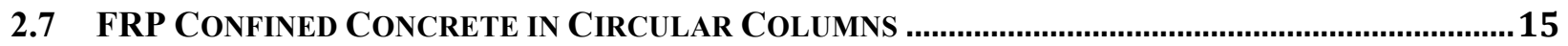

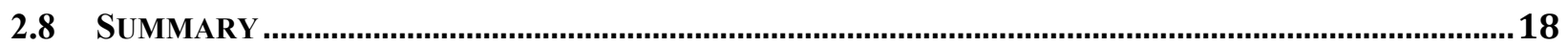

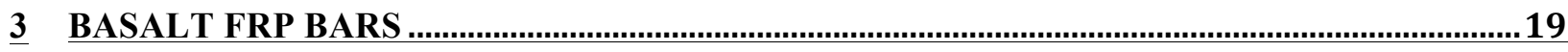

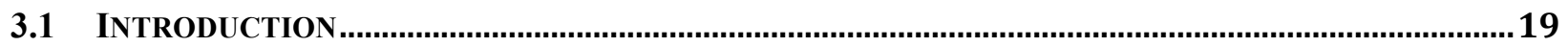

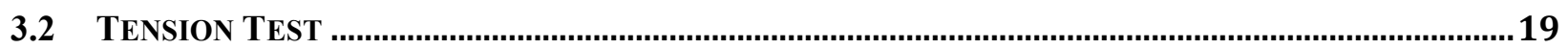

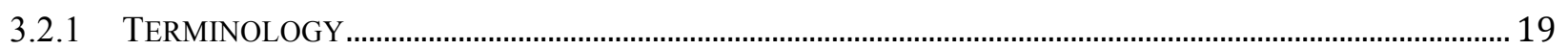

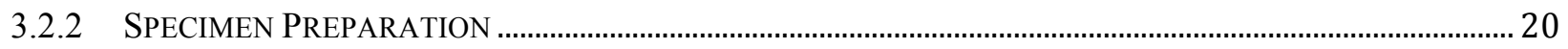

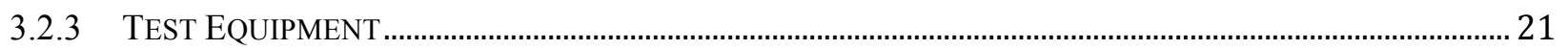

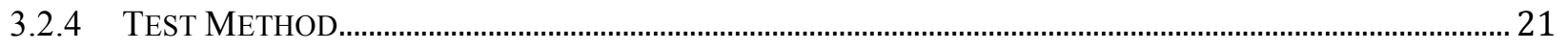

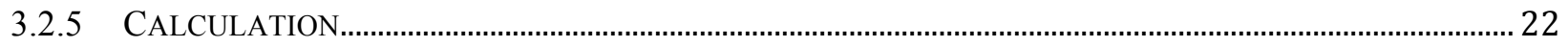

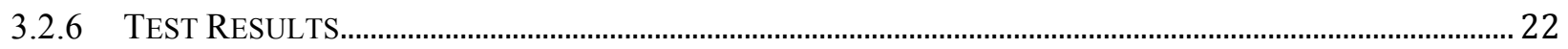

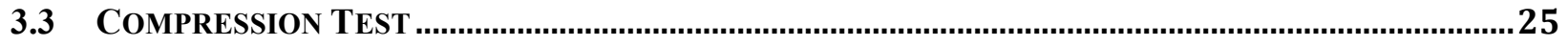

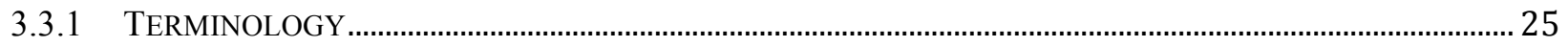

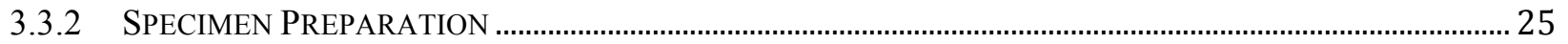

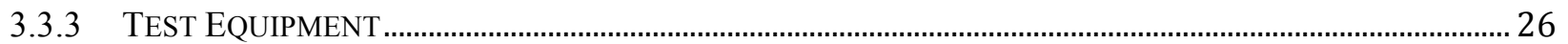

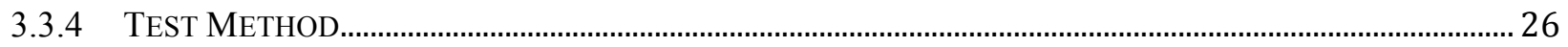

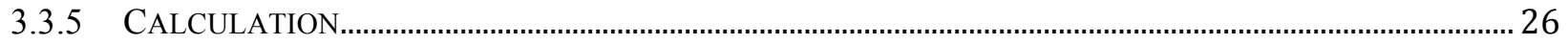

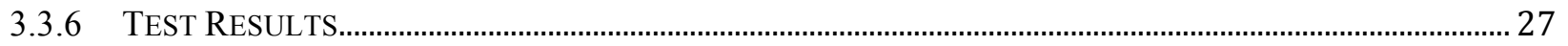

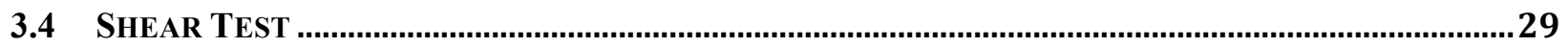

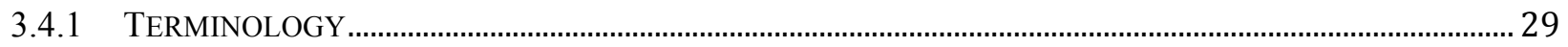

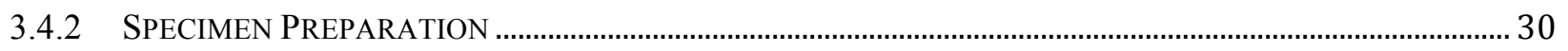

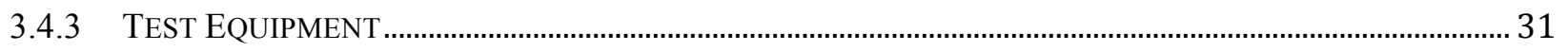

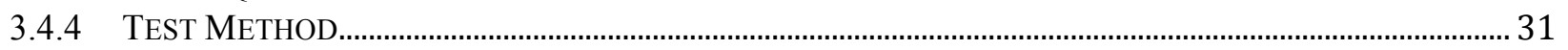

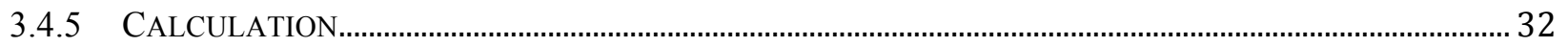

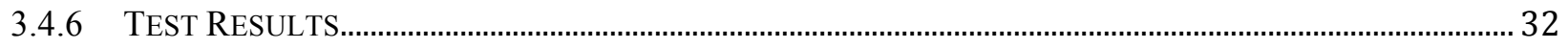

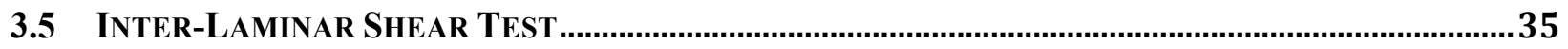

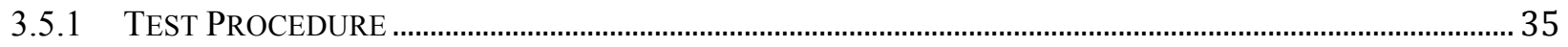




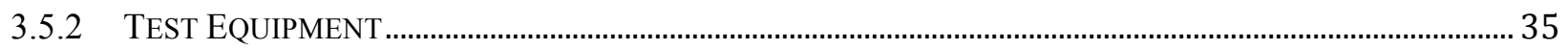

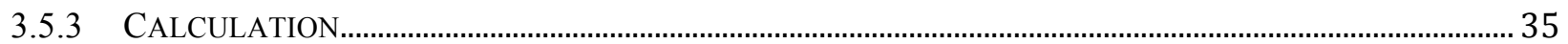

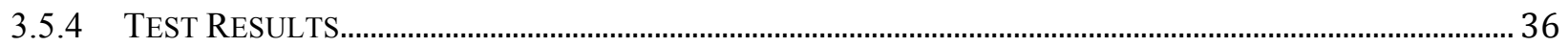

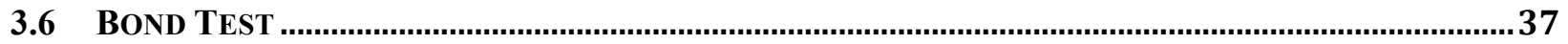

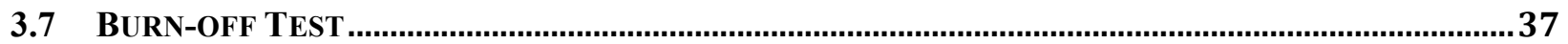

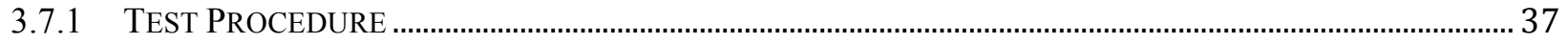

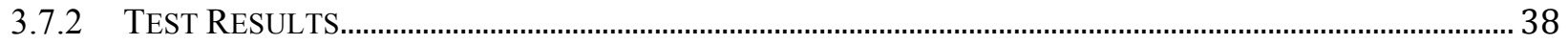

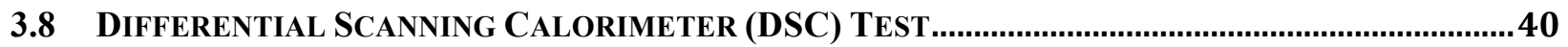

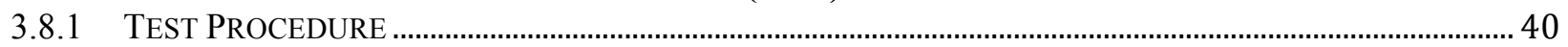

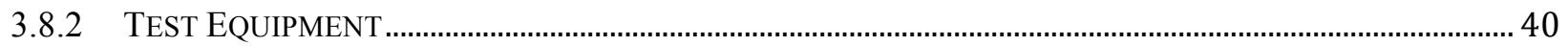

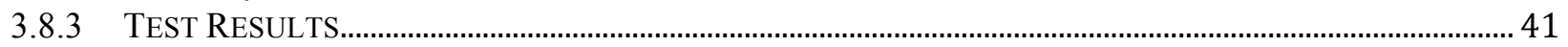

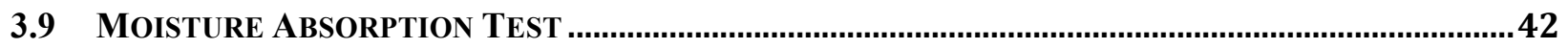

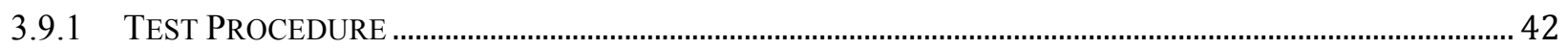

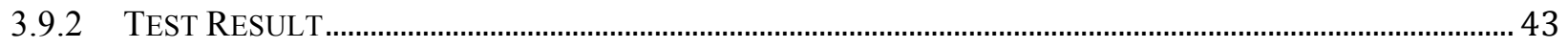

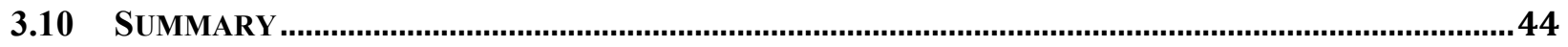

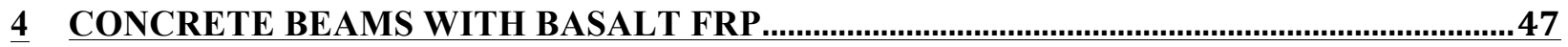

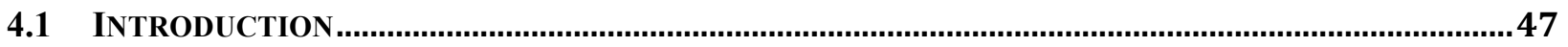

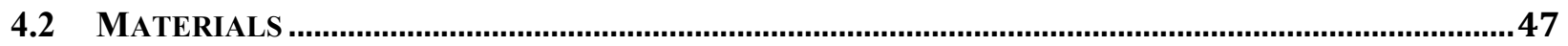

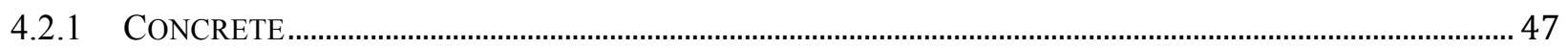

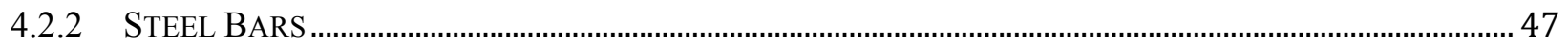

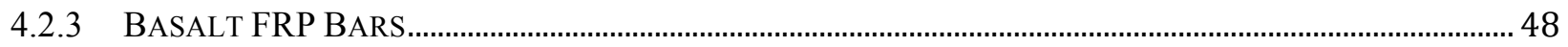

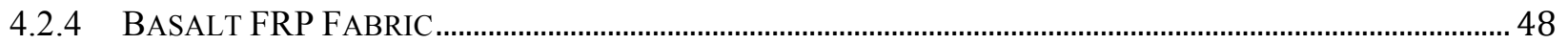

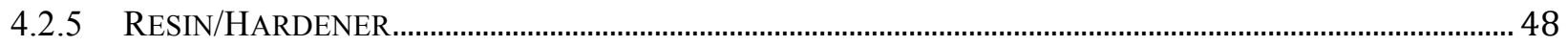

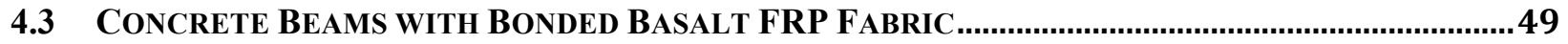

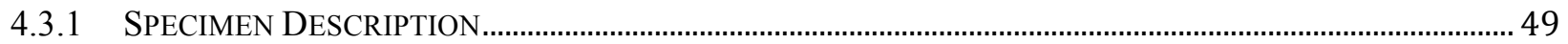

4.3.2 PROCEDURE OF BENDING CONCRETE BEAMS WITH BFRP FABRICS …................................................ 49

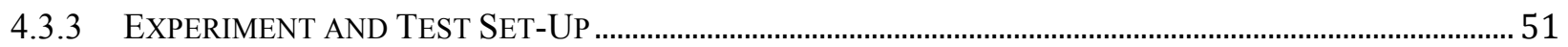

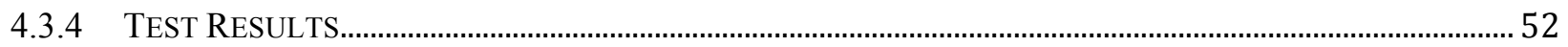

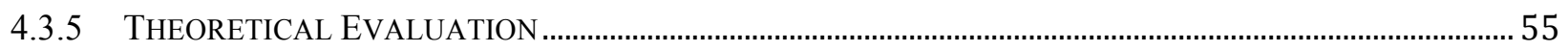

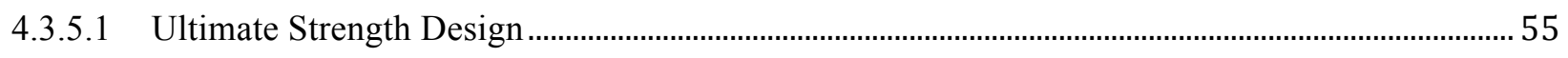

4.4 CONCRETE BEAMS WITH EXTERNAL AND INTERNAL BFRP REINFORCEMENT ..........................63

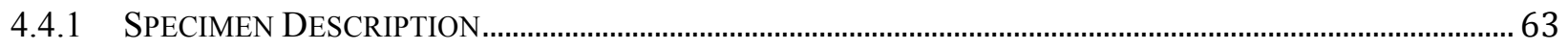

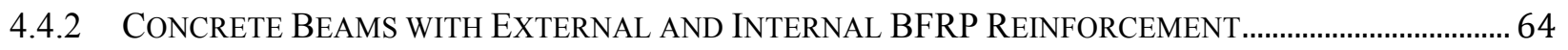

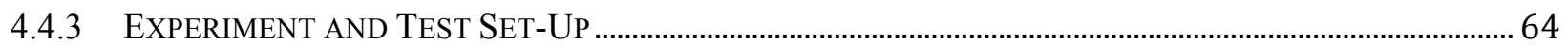

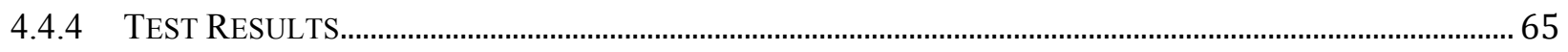

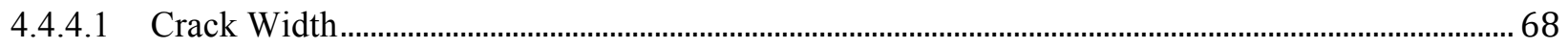

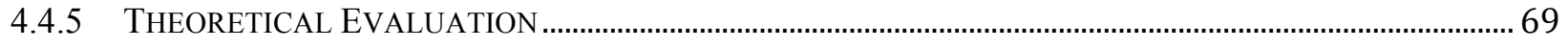

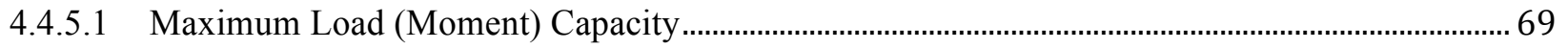

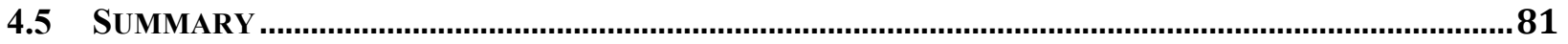

$\underline{5}$ EVALUATION OF CONCRETE CYLINDERS WRAPPED WITH BFRP ...............................83

5.1 INTRODUCTION

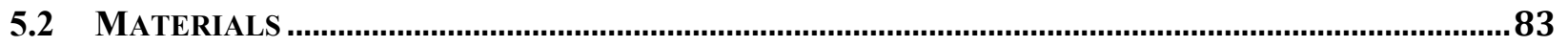

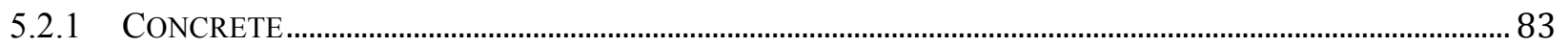

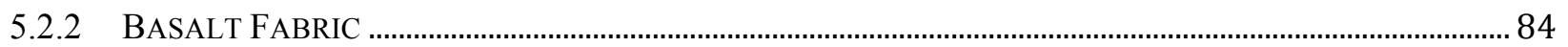

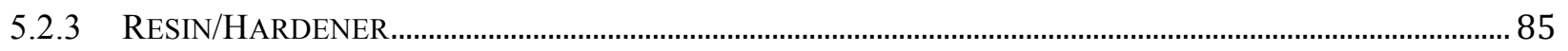

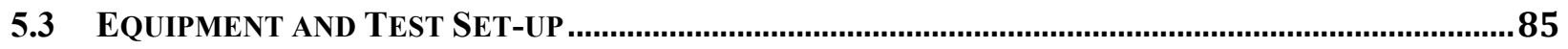

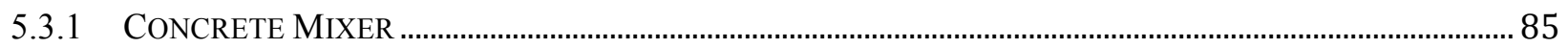




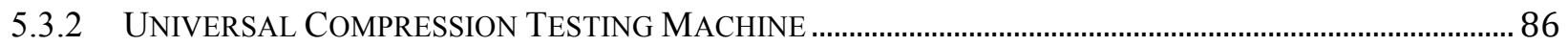

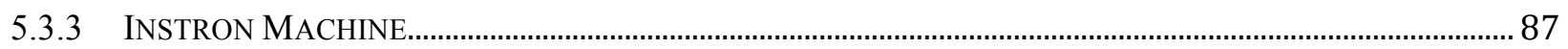

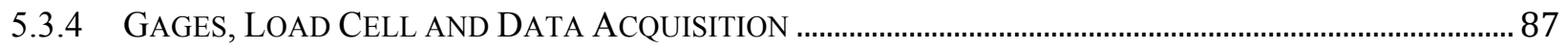

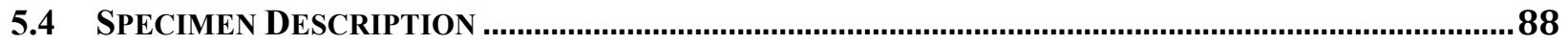

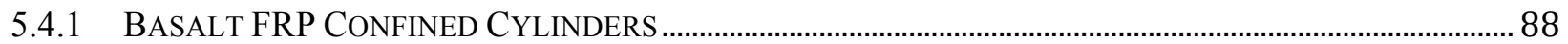

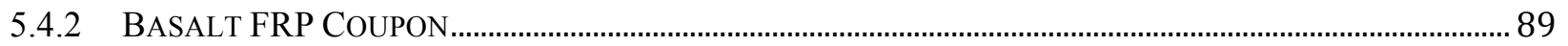

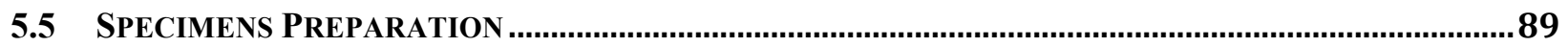

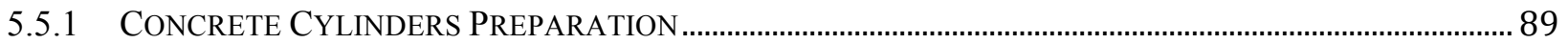

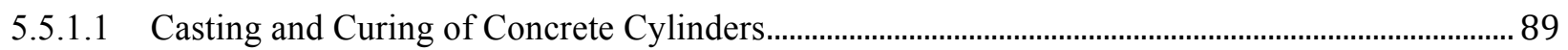

5.5.1.2 Wrapping of Concrete Cylinders with Basalt FRP Fabric .................................................................. 90

5.5.2 BASALT FRP COUPON PREPARATION............................................................................................... 92

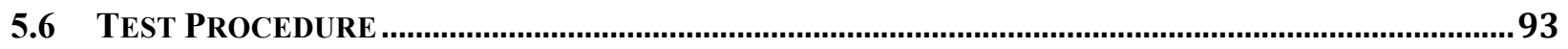

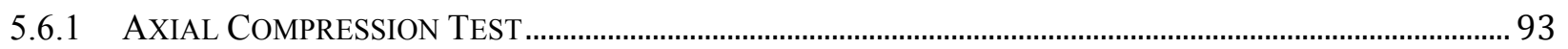

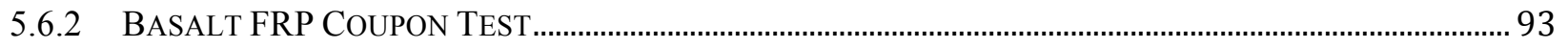

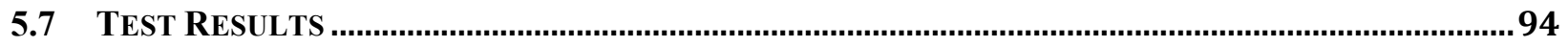

5.7.1 AXIAL COMPRESSION TEST TO DETERMINE THE EFFECT OF CONFINEMENT ......................................94

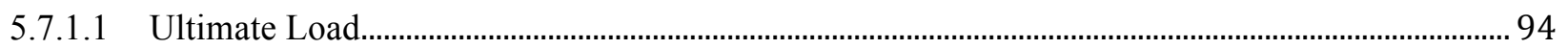

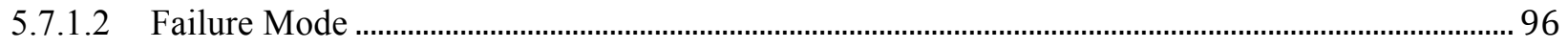

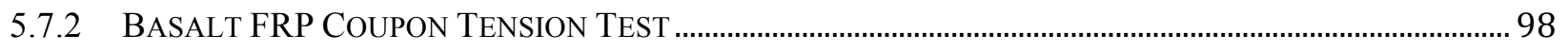

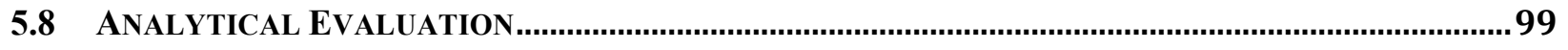

5.9 SUMMARY

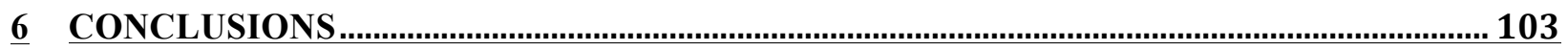

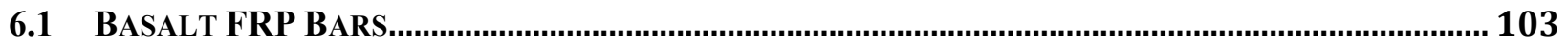

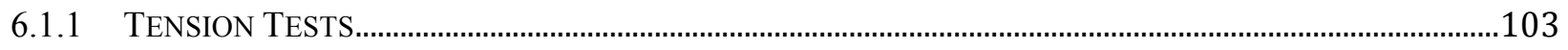

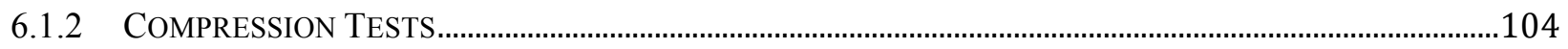

6.1.3 SHEAR TESTS..............................................................................................................................................104

6.1.4 INTER-LAMINAR SHEAR TESTS.................................................................................................................105

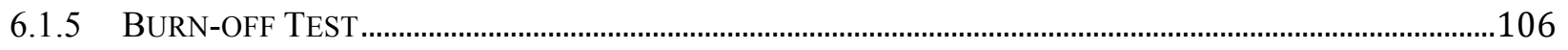

6.1.6 DIFFERENTIAL SCANNING CALORIMETER (DSC) TEST ….....................................................................106

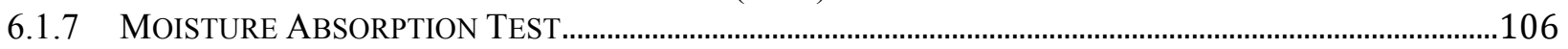

6.2 BEHAVIOR OF BEAMS WITH EXTERNAL AND INTERNAL BASALT FRP .................................... 106

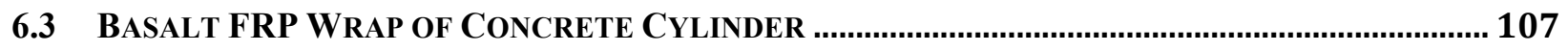

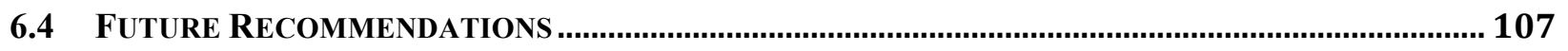

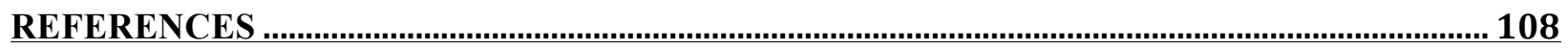

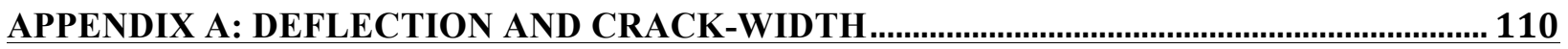




\section{List of Tables}

Table 2.1: Comparison of Chemical Component between Different Fibers ............................................. 9

Table 2.2: Compressive Strength of Concrete Specimens with Basalt Fibers......................................... 10

Table 2.3: Flexural Strength of Concrete Specimens with Basalt Fibers................................................. 10

Table 2.4: Mechanical Properties of Basalt, Carbon, E-Glass and S-Glass Fibers ................................ 12

Table 2.5: ACI Guaranteed Properties of Basalt Rebar (ACI 440.1R-06) …………............................... 13

Table 3.1: Tensile Test Result for \#4 Sand Coated BFRP Bar ................................................................. 23

Table 3.2: Tensile Test Result for \#5 Sand Coated BFRP Bar .................................................................. 24

Table 3.3: Compression Test Results for \#4 Sand Coated BFRP Bar .........................................................28

Table 3.4: Compression Test Results for \#5 Sand Coated BFRP Bar ....................................................... 28

Table 3.5: Single and Double Shear Test Results for \#4 Sand Coated BFRP Bar .................................. 33

Table 3.6: Single and Double Shear Tests Result for \#5 Sand Coated BFRP Bar .................................. 33

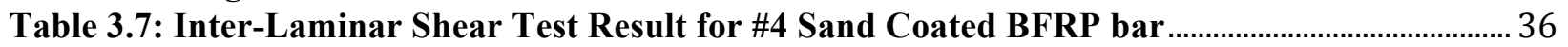

Table 3.8: Inter-Laminar Shear Test Result for \#5 Sand Coated BFRP bar ........................................... 36

Table 3.11: Results of Burn-off Tests for \#4 and \#5 BFRP Bar ............................................................... 39

Table 3.12: Maximum Moisture (Weight) gain of BFRP Bars ………....................................................... 43

Table 4.1: Four-point Bending Test Results of 6"x"15"x120" Beams Bonded with BFRP Fabric ... 53

Table 4.2: Number of BFRP Layers Bonded with Reinforced BFRP Bar ............................................ 64

Table 4.3: Maximum Load (moment) Capacities of 6"x"15"x72" Concrete Beam with BFRP

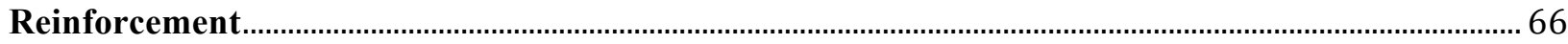

Table 4.4: Experimental Crack widths of Concrete Beams Reinforced with Internal and External

Basalt BFRP

Table 5.2: Strength of Control Specimens …………….......................................................................... 95

Table 5.3: Compressive Strength of Wrapped Cylinders from Batch 1 ................................................ 95

Table 5.4: Compressive Strength of Wrapped Cylinders from Batch 2 .................................................. 96

Table 5.5: Summarized Stress and Stiffness Values ................................................................................. 99

Table 5.6: Batch I Comparison of Experimental Results and Theoretical Results of Confined

Strength of Concrete .............................................................................................................................101

Table 5.7: Batch II Comparison of Experimental Results and Theoretical Results of Confined

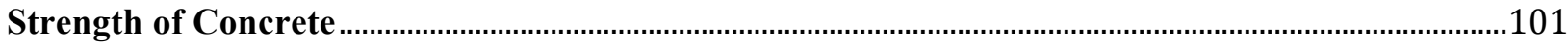

Table 6.1: Tensile Strength and Stiffness of Basalt FRP Bars ……...................................................103

Table 6.2: Compressive Strength and Stiffness of Basalt FRP Bars ...................................................104

Table 6.3: Single and Double Shear Strength of Basalt FRP Bars............................................................105

Table 6.4: Inter-Laminar Shear Strength of Basalt FRP Bars ...................................................................105

Table A.1: \#4 BFRP Beam Bonded with 2 Layers of BFRP fabric ……...............................................113

Table A.2: \#5 BFRP Beam Bonded with 1 Layer of BFRP fabric ……...........................................117 


\section{List of Figures}

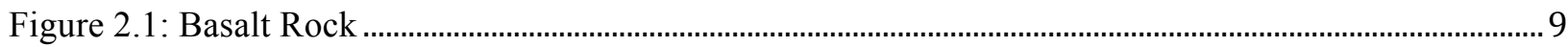

Figure 2.2: Free Body Diagram of Section of Confined Concrete..................................................................... 16

Figure 2.3: Lateral Expansion (Left) and Effect of Confinement (Right) ..................................................... 17

Figure 2.4: Stress-Strain curve for concrete specimen (Left) and Stress-Strain Curve for BFRP (Right) . 18

Figure 3.1: Tension Testing of BFRP Bar..................................................................................................... 21

Figure 3.2: \#4 and \#5 BFRP Specimen before (left) and after (Right) Tension Test ..................................... 23

Figure 3.3: Failure Mode of Compression Test Specimens for BFRP Bars ..................................................... 28

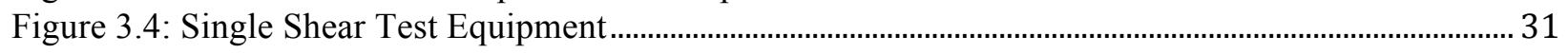

Figure 3.5: Single Shear Tests of BFRP Bar Specimens................................................................................. 33

Figure 3.6: Double Shear Tests of BFRP Bar Specimens ................................................................................... 34

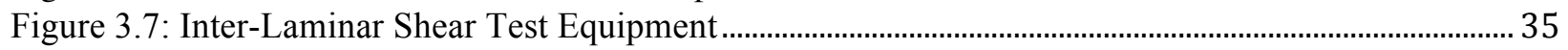

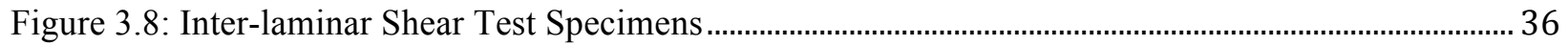

Figure 3.11: BFRP Specimen Before and After Burn-off Test......................................................................... 38

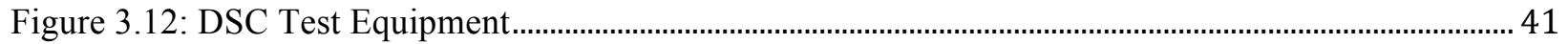

Figure 3.13: DSC Test Result of \#4 BFRP Specimen..................................................................................... 41

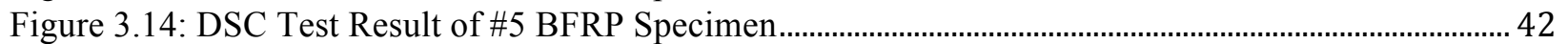

Figure 3.15: Moisture Absorption in \#4 Sand Coated BFRP Bars ................................................................... 43

Figure 3.16: Moisture Absorption in \#5 Sand Coated BFRP Bars .................................................................... 44

Figure 4.1: Formwork with Reinforcements for Concrete Beams .................................................................. 50

Figure 4.2: Damaged Area on the Beam Bottom (Tension Side) at L/3 …...................................................... 51

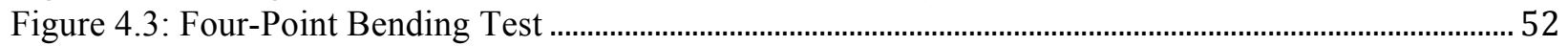

Figure 4.4: Failure Mode of Concrete Base Beam .............................................................................................. 54

Figure 4.5: Failure Mode of Concrete Beam Bonded with BFRP Fabrics......................................................... 54

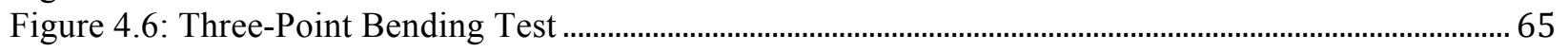

Figure 4.7: Failure Mode of Concrete with BFRP Bar Reinforcement (base)................................................... 67

Figure 4.8: Failure Mode of Concrete with BFRP Bar Reinforcement (base)................................................. 67

Figure 4.9: Cracked Concrete Beam with Internal and External BFRP Reinforcement................................... 68

Figure 5.1: Coarse and Fine Aggregates Used for Concrete Preparation .......................................................... 84

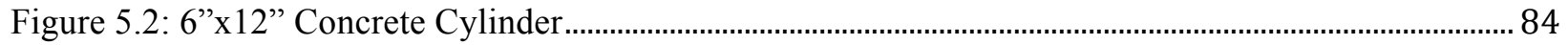

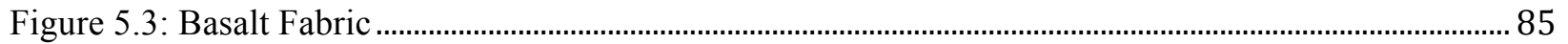

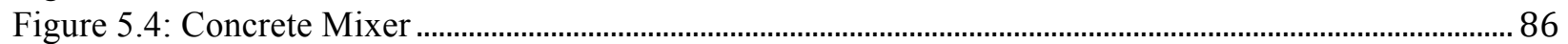

Figure 5.5: Universal Compression Testing Machine (Left) and Dial Gage (Right)..................................... 86

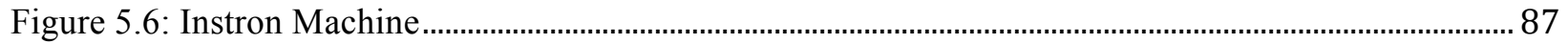

Figure 5.7: Data Acquisition (A\&C) System, and Load Cell (B) ................................................................... 88

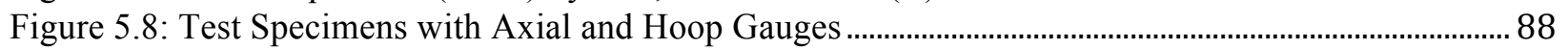

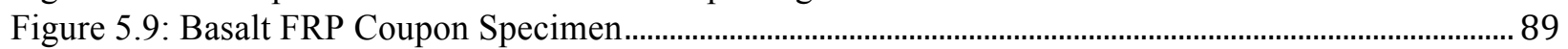

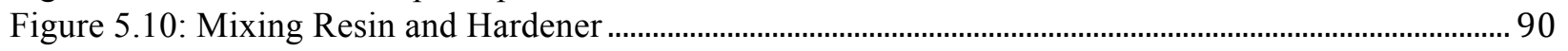

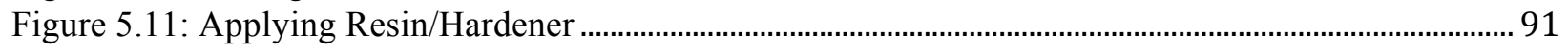

Figure 5.12: Wrapping Concrete Cylinder..................................................................................................... 91

Figure 5.13: Placing Wrapped Concrete Cylinder for Curing (top view) Over Seam................................... 91

Figure 5.14: Prepared BFRP Coupon Specimens …….................................................................................... 92

Figure 5.15: Test Set-up for Cylinder Compression Test ................................................................................ 93

Figure 5.16: Plain Concrete Specimens under Compression Test Batch1 (Left), Batch2 (Right) .............. 97

Figure 5.17: 1 Layer BFRP Concrete Cylinder Specimens Under Compression Test Batch1 (Left), Batch2

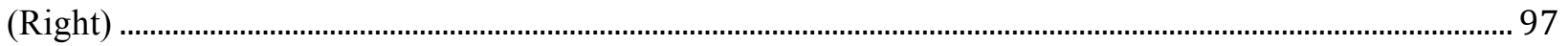

Figure 5.18: 2 Layer BFRP Concrete Cylinder Specimens Under Compression Test Batch1 (Left), Batch2

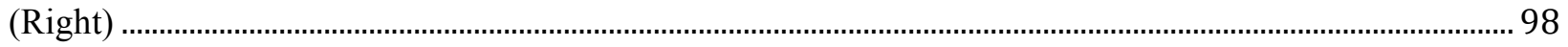


Figure 5.19: 3 Layer BFRP Concrete Cylinder Specimens Under Compression Test Batch1 (Left), Batch2 (Right)

Figure A.1: Load-Deflection Diagram of \#4 BFRP Beam Bonded with 2 Layers of BFRP Wrap ...........114

Figure A.2: Load-Deflection Diagram of \#4 BFRP Beam Bonded with 1 Layer of BFRP Wrap ..............118 


\section{Introduction}

\subsection{Introduction}

Deficiencies of plain concrete are characterized as deterioration, defect, and damage (Grieken, 2009). These deficiencies are due to cracking and spalling caused by corroding steel reinforcement, material imperfection, excessive loading, harsh, environmental conditions, creep, fatigue and others.

Steel reinforcing bars used in the concrete beams corrode under the presence of chloride, water, and air. They undergo oxidation due to chloride attack. The oxidation products have increased volume, which causes radial tensile stress around the bar in the concrete. As a result, the surrounding concrete cracks and exposes the steel to harsh environments, causing an acceleration in the corrosion process.

In order to safely rehabilitate structurally deficient reinforced concrete members such as beams and columns there is a need for better methods and techniques. Reinforced concrete (RC) columns are the lateral and vertical load resisting members in the structure and are particularly vulnerable to severe damages and collapse during an earthquake. Traditional retrofitting methods result in significant increase in the cross sectional area and self-weight of structures. On contrary, the use of strong and lightweight fiber reinforced polymers (FRP) for columns and beam-column junction will help enhance the strength and ductility of concrete structures against earthquake loads, higher loads and fatigue. Similarly, FRPs can help retrofit distressed steel reinforced concrete beams. 
According to the Federal Highway Administration (FHWA) report, nearly 24\% of the US nation's 610,749 bridges are structurally deficient and need to be rehabilitated/repaired or replaced (Deficient Bridges by State and Highway System, 2014). The rehabilitation process of existing structures is usually done using steel or reinforced concrete jacketing. The rehabilitation/replacement of a part or whole of the concrete structure could be sometimes more expensive than the structural replacement. In USA, the estimated cost to repair bridge deficiencies is approaching 300-billion US dollars annually (Basalt Rebar Manufacturer , 2015).

FRP composite fiber/fabrics and bars are currently being used in several structural systems. Strengthening of reinforced concrete columns with FRP wraps is one of the efficient methods to increase their strength and ductility. The American Concrete Institute (ACI) Committee 440 published state-of-the-art report (ACI 440.6-08) and other reports for designing, constructing, and rehabilitating structural reinforced concrete with FRP. ACI reports help in providing the guidelines, recommendations, and the information for FRP materials such as glass (GFRP), carbon (CFRP) and basalt (BFRP) (Patnaik, 2009) (Abdelrahman \& Raafat, 2014).

FRPs are made of reinforcing fibers and cured resins (polymer matrix). The main loadcarrying element in the FRP is fibers. The polymer matrix protects the fibers from damages and allows load distribution between individual fibers. Fiber selection is based on strength, stiffness and durability requirement for specific application. Resin selection is based on the type of fibers, function and manufacturing. Fibers such as glass and carbon are being currently used in the construction industry and basalt fibers are being newly introduced. Some of the advantages of 
FRPs are: high strength to weight ratio, non-corrosiveness, non-conduciveness, magnetic transparency, and lightness of weight.

This research focuses on the evaluation of the mechanical properties of basalt FRP (BFRP) bars and fabrics for reinforcing or strengthening concrete structures. Specifically, this work evaluates the confinement related strength and stiffness increase of FRP wrapped concrete cylinders and the behavior of concrete beams bonded with basalt FRP fabric and reinforced with basalt FRP bars.

\subsection{Objectives}

The main objectives of this research are as follows:

- Determine test methods to evaluate the mechanical properties of basalt FRP (BFRP) bars and fabrics.

- Study the behavior of concrete beams bonded with FRP fabrics.

- Study the behavior of concrete beams reinforced with FRP bars.

- Evaluate the confinement related strength, stiffness and ductility increase in concrete cylinders wrapped with basalt FRP fabric in terms of:

Concrete compressive strength $\left(f_{c}^{\prime}\right)$

$>$ Number of BFRP wraps 


\subsection{Scope}

\subsubsection{FRP bars}

Short-term tests were conducted on basalt FRP (BFRP) bars to determine their basic strength properties that includes tensile, bending, shear, and bond strength. Also, stiffness (Young's Modulus, E) of the BFRP bars was evaluated. Bars with 1/2" (\#4) and 5/8" (\#5) in diameter were tested to find the effect of the bar diameter for a particular property.

Scope of short-term tests are summarized below:

a) Tension tests: This test involves tensile loading up to failure to determine ultimate strength and stiffness of the bar using data from load cell, strain gage, and data acquisition system.

b) Compression tests: This test involves compressive loading up to failure to determine ultimate strength and stiffness of the bar using data from load cell, strain gage, and data acquisition system.

c) Shear tests: This test is done to evaluate the shear strength of FRP bars with a shearing width of $1 / 2$ ". Single and double shear tests were performed to determine the effect of anchoring the specimens to the fixture in each method with respect to stress value.

d) Bond test: This test is performed to determine the bond strength of the FRP bars using concrete cylinder pull-out tests. In this test, the concrete is subjected to compression and the reinforcing BFRP bar is subjected to tension during the bar pull-out process. 
e) Burn-off test: This test is performed to evaluate the mass and volume fractions content of resin and fiber in BFRP bar.

f) Differential Scanning Calorimeter (DSC) test: This test is done to determine the thermal and curing properties of the resin. The resin glass transition temperature of the basalt FRP bar was found from DSC testing.

g) Moisture absorption: This test is done to determine the percentage of moisture gain of basalt FRP bar when immersed in water for a period of about 360 hours.

\subsubsection{Concrete Beams}

Two types of concrete beams were tested under the following configuration:

$>$ Bonded with basalt FRP fabrics on the tension zone

$>$ Reinforced with basalt FRP bars in the tension zone

Parameters evaluated:

Beams: maximum load (moment), deflection, and crack width.

- Beams with external BFRP reinforcement:

Beam configuration: $\quad$ 1) 2 longitudinal layers at the beam bottom

2) 3 longitudinal layers at the beam bottom 
- Beams with External and Internal BFRP reinforcement:

Beam configurations: $\rightarrow$ Internal reinforcement:

- \#4 (diameter $=0.5 ”)$ BFRP bar

$\rightarrow$ External reinforcement:

- Bonded with 1 layer of BFRP fabric

- Bonded with 2 layers of BFRP fabric

$\rightarrow$ Internal reinforcement:

- $\quad \# 5($ diameter $=0.625 ")$ BFRP bar

$\rightarrow$ External reinforcement:

- Bonded with 1 layer of BFRP fabric

- Bonded with 2 layers of BFRP fabric

\subsubsection{FRP Wrapped Concrete Cylinders}

BFRP wrapped and non-wrapped concrete cylinders were subjected to axial compressive loads to find the effects of confinement. Wrapping and testing of 6" $\mathrm{x} 12$ " concrete cylinders with 1, 2, and 3 layers of FRP fabrics using epoxy resins were carried out to evaluate their increase in strength and stiffness. Casting was done in two batches of 12 cylinders each for $f_{c}^{\prime}$ of 4000-psi and $f_{c}^{\prime}$ of 6000 -psi 


\subsection{Summary}

The research work presented in this report is summarized below:

$\Rightarrow$ Chapter 2: A review of research findings, performance data and current studies related to basalt FRP bars and fabrics, behavior of concrete beams reinforced with BFRP bars, and concrete cylinders bonded with BFRP fabrics is presented in this chapter.

$\Rightarrow$ Chapter 3: This chapter includes the properties of BFRP bars and different test methods. Material, equipment, and test procedure are described in detail.

$\Rightarrow$ Chapter 4: The behavior of concrete beams reinforced with BFRP bars and wraps are presented in this chapter. Material, equipment, and test procedure are described in details. A comparison of experimental and theoretical results are provided and discussed.

$\Rightarrow$ Chapter 5: This chapter consists of details on the testing of BFRP wrapped concrete cylinders. Material, equipment, and test procedure are described in detail. A comparison of experimental and theoretical results are provided and discussed.

$\Rightarrow$ Chapter 6: This chapter summarizes the overall conclusions and general recommendations. 


\section{Literature Review}

\subsection{Introduction}

This chapter contains a review of published research and current studies on BFRP fibers and composites. Sections $2.2-2.4$ have a brief summary of basalt rock, production cost of fibers and their properties. Section 2.5 provides a review of the short-term mechanical properties of BFRP bars. Section 2.6 describes the behavior of concrete beams reinforced with BFRP bars and wrapped with BFRP fabrics. Section 2.7 focuses on the behavior of wrapped concrete cylinders.

\subsection{Basalt}

Basalt can commonly be found in the earth's crust. Also, it is common on the moon and other rocky planets of the solar system (Basalt, 2016). Basalt (Figure 2.1) with black or grey appearance is a fine-grained volcanic rock formed by decompression of earth's mantle. Basalt is composed of calcic plagioclase (laboradirite), clinopyroxene (augite), and iron ore (titaniferous magnetite). It contains $45-52 \%$ of $\mathrm{SiO}_{2}$ and less than $5 \%$ of total alkalies $\left(\mathrm{K}_{2} \mathrm{O}+\mathrm{Na}_{2} \mathrm{O}\right)$. Also, it contains olivine, quartz, hornblende, nepheline, etc.

There is some variation in the chemical composition of basalt based on its origin. MidOcean Ridge Basalt (MORB) is due to partial melting of the upper mantle, while the Oceanic Island Basalt (OIB) is from the deeper part of the mantle with fewer chemical elements. An average chemical composition of basalt is determined by about 3590 chemical analyses of basaltic rocks. Augite, plagioclase and titaniferous magnetite present in small quantities are the 
minerals that hold the chemical elements in basalt rock. A comparison of chemical composition of different fibers used in FRP composites such as glass, carbon and basalt is provided in Table 2-1 (Parnas, Shaw, \& Liu, 2007).

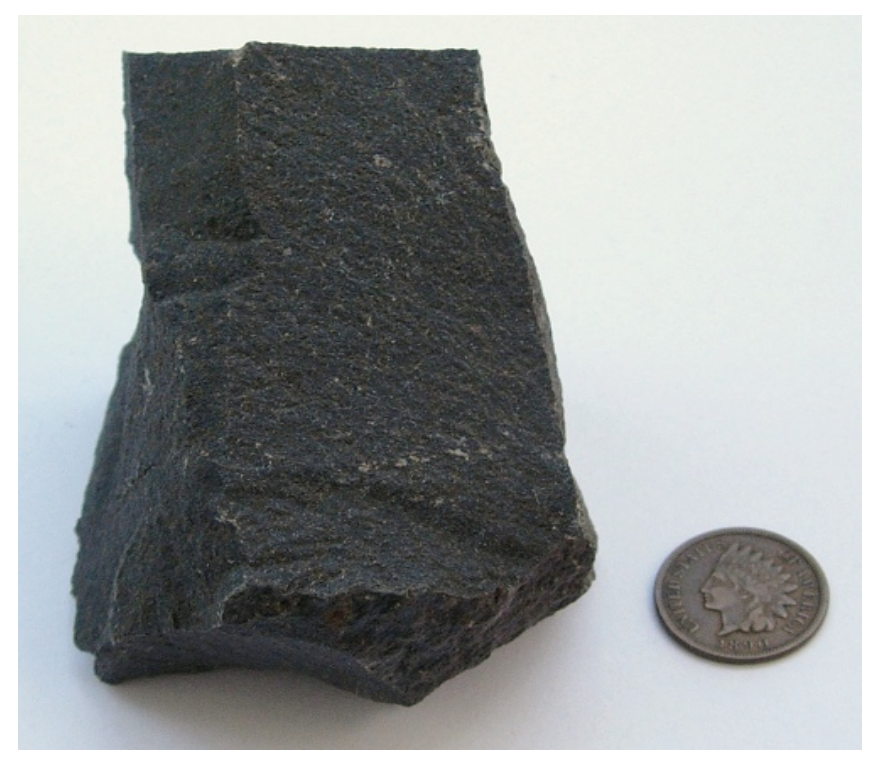

Figure 2.1: Basalt Rock

Table 2.1: Comparison of Chemical Component between Different Fibers

\begin{tabular}{|l|c|c|c|}
\hline Chemical composition \% & Basalt & E-Glass & S-Glass \\
\hline Silicon Dioxide, $\mathrm{SiO}_{2}$ & $48.8 \sim 51$ & $52-56$ & $64-66$ \\
\hline Aluminum $\mathrm{Oxide}_{2} \mathrm{Al}_{2} \mathrm{O}_{3}$ & $14 \sim 15.6$ & $12-6$ & $24-26$ \\
\hline Iron Oxide, $\mathrm{Fe}_{2} \mathrm{O}_{3}+\mathrm{FeO}$ & $7.3 \sim 13.3$ & $0.05-0.4$ & $0-0.3$ \\
\hline Calcium Oxide, $\mathrm{CaO}$ & 10 & $16-25$ & $0-0.3$ \\
\hline Magnesium Oxide, $\mathrm{MgO}$ & $6.2 \sim 16$ & $0-5$ & $9-11$ \\
\hline $\begin{array}{l}\text { Sodium Oxide+ Potassium Oxide, } \\
\mathrm{Na}_{2} \mathrm{O}+\mathrm{K}_{2} \mathrm{O}\end{array}$ & $1.9 \sim 2.2$ & $0-2$ & $0-0.3$ \\
\hline Titanium Oxide, $\mathrm{FiO}_{2}$ & $0.9 \sim 1.6$ & $0-0.8$ & - \\
\hline
\end{tabular}

Irine (2014) investigated the compressive and flexural tensile strength of basalt fiber reinforced plain (M30 grade) concrete. Materials used in the mix were $240-\mathrm{kg} / \mathrm{m}^{3}$ of cement, 
$828-\mathrm{kg} / \mathrm{m}^{3}$ of fine aggregate, and $1123-\mathrm{kg} / \mathrm{m}^{3}$ of coarse aggregate. The water cement ratio was 0.45. Basalt fibers were chopped and distributed randomly in the concrete matrix. Different fiber contents of $1-\mathrm{kg} / \mathrm{m}^{3}, 2-\mathrm{kg} / \mathrm{m}^{3}$ and $4-\mathrm{kg} / \mathrm{m}^{3}$ were chosen for the concrete mix. Compressive strength test was measured at 3,7 , and 28 days. The addition of $4-\mathrm{kg} / \mathrm{m}^{3}$ basalt fiber resulted in highest compressive strength with an increase of $14 \%$ as compared to the plain concrete mix (see Table 2-2). Flexural strength was measured at 7 and 28 days and the results (Table 2-3 show an increase of $54 \%$ for an addition of $4-\mathrm{kg} / \mathrm{m}^{3}$ basalt fiber to the content mix (Irine, 2013).

Table 2.2: Compressive Strength of Concrete Specimens with Basalt Fibers

\begin{tabular}{|c|c|c|c|}
\hline \multirow{2}{*}{$\begin{array}{c}\text { Basalt Fiber } \\
\left(\mathrm{kg} / \mathrm{m}^{3}\right)\end{array}$} & \multicolumn{3}{|c|}{ Compressive Strength (N/mm2) [ksi] } \\
\cline { 2 - 4 } & 3 Days & 7 Days & 28 Days \\
\hline 0 & $19.3[2.80]$ & $25.1[3.64]$ & $35.4[5.13]$ \\
\hline 1 & $20.37[2.95]$ & $25.67[3.72]$ & $36.5[5.29]$ \\
\hline 2 & $21.6[3.13]$ & $27.75[4.02]$ & $38.4[5.57]$ \\
\hline 4 & $22.2[3.22]$ & $28.89[4.19]$ & $40.2[5.83]$ \\
\hline
\end{tabular}

Table 2.3: Flexural Strength of Concrete Specimens with Basalt Fibers

\begin{tabular}{|c|c|c|}
\hline \multirow{2}{*}{$\begin{array}{c}\text { Basalt Fiber } \\
\left.\mathrm{kg} / \mathrm{m}^{3}\right)\end{array}$} & \multicolumn{2}{|c|}{ Flexural Strength $\left(\mathrm{N} / \mathrm{mm}^{2}\right)[\mathrm{ksi}]$} \\
\cline { 2 - 3 } & 7 Days & 28 Days \\
\hline 0 & $3.3[0.48]$ & $5.2[0.75]$ \\
\hline 1 & $4.2[0.61]$ & $5.8[0.84]$ \\
\hline 2 & $4.8[0.70]$ & $6.6[0.96]$ \\
\hline 4 & $6.2[0.90]$ & $8[1.16]$ \\
\hline
\end{tabular}




\subsection{Cost of Basalt Fiber Production}

Raw materials required for basalt fiber production are inexpensive and available around the world, especially in Russia and India (Kumbhar, 2014). Generally, the base cost of basalt fibers varies and depends on the type of raw materials, and their quality, production process, and characteristics of the final product. Basalt fiber production is similar to that of the glass fiber production, expect for the addition of ingredients such as aluminum during glass production (Ross, 2006), which makes it cheaper than glass and carbon fibers (Fiore et al., 2015). The energy required for melting basalt rock is higher than the E-glass fiber. (Kumbhar, 2014).

Basalt fibers have several advantages that make them a good alternative to glass and carbon fibers for reinforcing FRP composites. It can be used in several fields such as sporting equipment, automotive, and marine, etc. (Fiore et al, 2015). According to several studies processing of basalt and alignment results in at least $16 \%$ higher modulus, better alkaline resistance, and equivalent tensile strength comparing to E-glass fibers (Binertury et al., 1997).

Cost of basalt fibers/fabrics are expected to be slightly higher than glass and much lower than carbon. However, the higher mechanical properties of basalt fibers as compared to glass fibers make them very competitive for structural applications.

\subsection{Basalt Fiber Properties}

Majority of fibers used in the civil engineering industry are carbon and glass, which are known as CFRP and GFRP, respectively. Basalt FRP (BFRP) is a new alternative reinforcement in the industry. Table 2.3 shows the properties of various fibers such as basalt, carbon, E-glass 
and S-glass. Basalt fibers contain natural materials without any additives, and their tensile strength and elastic modulus are 30\% higher than E-glass and S-glass fibers. Basalt fibers have higher temperature resistance as compared to carbon and glass fibers.

Caiyun and Fengjing, in 2010, studied the acid and alkali resistance of basalt fibers. It has been found that basalt fibers are better than carbon and glass fibers when subjected to acidic and alkaline environments and have stable chemical properties. Also, basalt fibers are better at resisting acids than alkalis. (Caiyun \& Fengjing , 2010)

Table 2.4: Mechanical Properties of Basalt, Carbon, E-Glass and S-Glass Fibers

\begin{tabular}{|c|c|c|c|c|}
\hline \multirow{3}{*}{$\begin{array}{l}\text { Manufacturing } \\
\text { Process }\end{array}$} & $\begin{array}{c}\text { Basalt } \\
\begin{array}{c}\text { Crushed } \\
\text { basalt }\end{array}\end{array}$ & $\begin{array}{c}\text { Carbon } \\
\text { PAN } \\
\text { PITCH }\end{array}$ & E-Glass & S-Glass \\
\hline & \multirow{2}{*}{$\begin{array}{c}\text { Crushed } \\
\text { basalt }\end{array}$} & \multirow{2}{*}{$\begin{array}{c}\text { PAN } \\
\text { PITCH }\end{array}$} & \multirow{2}{*}{\multicolumn{2}{|c|}{ Melting Silica in furnace }} \\
\hline & & & & \\
\hline $\begin{array}{l}\text { Tensile strength } \\
\text { (ksi) }\end{array}$ & $400-695$ & $500-640$ & $450-500$ & $580-670$ \\
\hline $\begin{array}{l}\text { Elastic Modulus } \\
\text { (ksi) }\end{array}$ & $13,500-16,000$ & $33,300-116,000$ & $10,500-11,000$ & $12,000-12,500$ \\
\hline Strain $(\%)$ & $3.1-6$ & $0.5-1.5$ & 4.7 & 5.3 \\
\hline $\begin{array}{l}\text { Specific gravity } \\
\left(\mathrm{g} / \mathrm{cm}^{\wedge} 3\right)\end{array}$ & $2.65-2.8$ & $1.75-1.95$ & $2.5-2.65$ & 2.46 \\
\hline $\begin{array}{l}\text { Max. Temperature } \\
\text { of Application } \\
\text { (fibers) }\left({ }^{\circ} \mathrm{C}\right)\end{array}$ & $\sim 650$ & $\sim 400$ & $\sim 350$ & $\sim 500$ \\
\hline Melting Temp. $\left({ }^{\circ} \mathrm{C}\right)$ & 1450 & - & 1120 & 1550 \\
\hline$\%$ wt. loss after $3 \mathrm{hc}$ & s boiling in: & & & \\
\hline $\mathrm{H}_{2} \mathrm{O}$ & 0.2 & - & 0.7 & 0.05 \\
\hline $2 \mathrm{~N} \mathrm{NaOH}$ & 5 & - & 6 & 5 \\
\hline $2 \mathrm{~N} \mathrm{HCl}$ & 2.2 & - & 38.9 & 15.7 \\
\hline
\end{tabular}

Basalt fibers are slightly stronger and stiffer than glass, non-toxic, non-corrosive, nonmagnetic, and environmentally safe. Basalt fibers offer the opportunity to engineer their 
mechanical properties by modifying their chemical composition listed in Table 2.1, which results in having higher elastic modulus and bio-solubility than glass fibers.

\subsection{BFRP Bar}

BFRP composite rebar have several advantages over steel rebar. Basalt rebar weighs less than the weight of the steel with twice the tensile strength. In addition, basalts are little lighter than glass and have a little higher tensile strength than glass fibers as per 440.1R-06 is shown in Table 2.5.

Table 2.5: ACI Guaranteed Properties of Basalt Rebar (ACI 440.1R-06)

\begin{tabular}{|c|c|c|c|c|c|c|c|c|c|}
\hline \multicolumn{3}{|c|}{ Diameter } & \multicolumn{2}{|c|}{ Nominal Area } & \multicolumn{3}{|c|}{ Gauranteed Tensile } & \multicolumn{2}{|c|}{ Tensile Modulus } \\
\hline size & $\mathrm{mm}$ & in & $\mathrm{mm}^{2}$ & $i n^{2}$ & $P_{s i}$ & $K s i$ & $\mathrm{Mpa}$ & Gpa & $\operatorname{psi} 10^{6}$ \\
\hline \#2 & 6 & $1 / 4$ & 31 & 0.054 & 125,000 & 125 & 862 & 40.8 & 5.92 \\
\hline \#3 & 10 & $3 / 8$ & 86 & 0.121 & 115,000 & 115 & 793 & 40.8 & 5.92 \\
\hline$\# 4$ & 13 & $1 / 2$ & 139 & 0.206 & 105,000 & 105 & 724 & 40.8 & 5.92 \\
\hline$\# 5$ & 16 & $5 / 8$ & 211 & 0.322 & 100,000 & 100 & 689 & 40.8 & 5.92 \\
\hline \#6 & 19 & $3 / 4$ & 295 & 0.459 & 95,000 & 95 & 655 & 40.8 & 5.92 \\
\hline \#7 & 22 & $5 / 8$ & 391 & 0.619 & 90,000 & 90 & 621 & 40.8 & 5.92 \\
\hline \#8 & 25 & 1 & 505 & 0.809 & 85,000 & 85 & 586 & 40.8 & 5.92 \\
\hline$\# 9$ & 29 & $11 / 8$ & 670 & 1.008 & 80,000 & 80 & 552 & 40.8 & 5.92 \\
\hline
\end{tabular}

Carbon (CFRP), glass (GFRP), and Aramid (AFRP) fibers are used nowadays as Reinforcing bars for concrete structures. Some of these bars have high initial cost, are not resistant to alkalis, and may have questionable durability under extreme environments. (Ramakrishnnan, 1993) (ACI, 1997). 
(Brik, 1997), found that basalt fibers strongly affect the toughness of concrete such that basalt fibers changed the sudden brittle failure of plain concrete to ductile failure. This is a result of the increased energy absorption caused by the gradual pullout behavior.

A recent study done by the University of Miami focused on basalt FRP rebars to determine the physical and mechanical properties. The International Building Code (IBC) and Florida Department of Transportation (FDOT) certified the test results. Basalt FRP bars were made from continuous fibers, in an epoxy resin and coated in sand surface. The tensile strength of \#4 and \#5 BFRP bar were $135 \mathrm{ksi}$ and $115 \mathrm{ksi}$, respectively, with an average modulus of elasticity of $\sim 7$ Msi. The average ultimate shear strength of BFRP bars were 22-29 ksi. The glass transition $\left(T_{g}\right)$ of BFRP bar was $109^{\circ} \mathrm{C}$, where specimen changes from hard, brittle region to soft, rubbery region (University of Miami, 2016).

\subsection{Concrete Beams with FRP Reinforcement}

Concrete beams are one of the important elements in structural industry. Strengthening of reinforced concrete beams with FRP have been studied in the past years. Commonly used fibers in the civil engineering applications are carbon (CFRP), glass (GFRP), and aramid (AFRP). Basalt (BFRP) is an alternative FRP reinforcement compared to CFRP, GFRP and AFRP. Reinforced concrete beams usually fail in two ways; shear failure and flexural failure. Sveinsdóttir (2012) bonded BFRP sheet as external reifnrocment to concrete beams and the tested under four point loading. Bending test results showed a strength increase between $20 \%$ to 60\% (Sveinsdóttir, 2012). 
Banibayat (2011) have investigated the behavior of beams reinforced with BFRP bar. The study shows that BFRP bars reinforced with concrete beams slow a flexural behavior similar to those of GFRP reinfroced bars. Through the ACI. 440 equations on strength and sercivibilty can be used at lower loads levels. Some modifications are suggested for improved modeling accuray (Banibayat , 2011).

\subsection{FRP Confined Concrete in Circular Columns}

FRP wrapped concrete columns are used in repair, retrofit, rehabilitation, and strengthening of infrastructure. Compared with the non-wrapped concrete columns, strength, ductility and durability are improved in FRP wrapped concrete columns (Parvin \& Brighton, 2014). Advantages of composites include are high strength to weight ratio, corrosion resistance, fatigue resistance, chemical and environmental resistance, and the availability in different length or shape.

Due to confinement effect of the wrap around concrete, there is an increase in strength, stiffness and ductility. Concrete columns are wrapped with BFRP using resin matrix when compressive load is applied on the wrapped concrete specimen, it causes an expansion of the column in hoop (circumferential) direction causing tensile in the FRP wrap in the hoop direction. Tensile stress in the hoop direction is balanced by a uniform radial pressure which reacts against the lateral expansion of concrete (Benzaid \& Mesbah, 2013). Figure 2.2 shows the confinement effect of composite FRP on concrete due to axial compression and lateral expansion of the wrapped specimen to achieve confinement (Rajappa, 2004). 


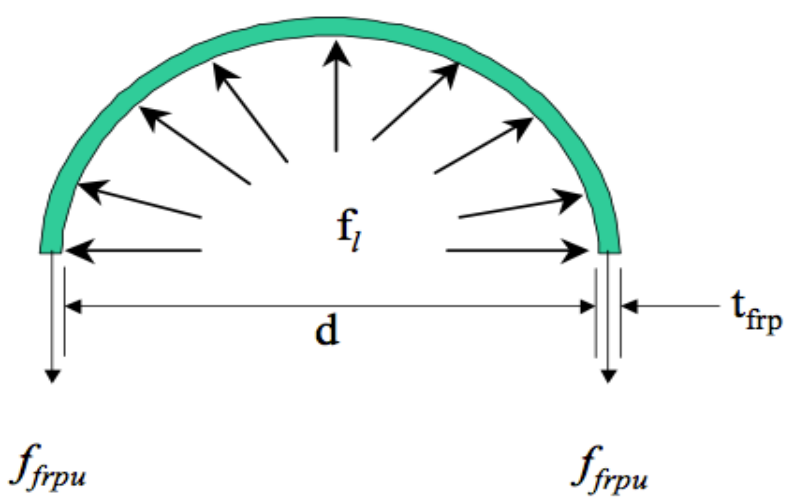

Figure 2.2: Free Body Diagram of Section of Confined Concrete

The lateral confining pressure $\left(f_{l}\right)$ can be calculated using the following equation:

$$
f_{l}=\frac{f_{f r p u} t_{f r p}}{r}=\frac{2 f_{f r p u} t_{f r p}}{d}
$$

Where:

$f_{\text {frpu }}=$ Ultimate Tensile Strength of Circular Confined Concrete (ksi)

$f_{l}=$ Lateral Confining Pressure $(\mathrm{ksi})$

$t_{f r p}=$ Thickness of FRP (inches) (0.024")

$r \& d=$ Radius and diameter of Cylinder, respectively (inches)

$f_{\text {frpu }}=E_{\text {frp }} \epsilon_{f r p u}$

Where:

$E_{f r p}=$ Elastic modulus of FRP

$\epsilon_{f r p u}=$ Strain of FRP 

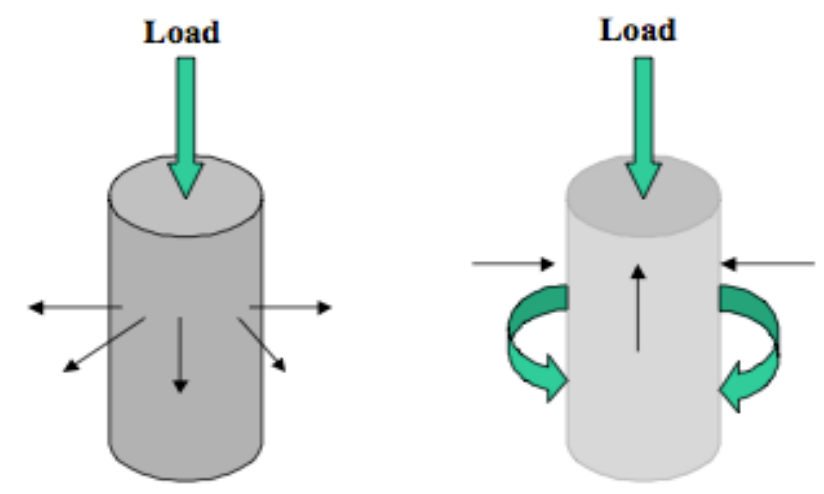

Figure 2.3: Lateral Expansion (Left) and Effect of Confinement (Right)

A study was conducted by Thorhallsson (2011) to determine the tensile strength of basalt FRP composite and the strength of BFRP confined concrete cylinders. A specimen of single layer of BFRP coupons with a dimension of $25 \mathrm{~mm}(0.98 \mathrm{in})$ width and $250 \mathrm{~mm}$ (9.8 in) length was prepared and attached with longitudinal strain gage to determine the percentage strain and therefore the tensile strength. The elastic modulus of BFRP composite was found to be 28871 MPa (4187 ksi) with $2.71 \%$ elongation strain. The same study focused on the behavior of basalt fibers wrapped on 4 "x8" concrete cylinders. A total of 12 concrete cylinders with 4 in $x 8$ in were cast with concrete. Three identical cylinder specimens were tested with $0,1,2$, and 3 number of layers. Cylinders were cured for 14 days. Confined cylinders with BFRP fabric showed good ductile behavior with the maximum axial strain being 12.7 times the unconfined peak strain. Similarly, the corresponding compressive strength was 2.9 times more than the unconfined concrete strength. Figure 2.4 shows compressive and tensile stress vs. cylinders with and without wrapping and also that of the BFRP fabrics strain graph of concrete specimens. (Thorhallsson et al, 2011) 

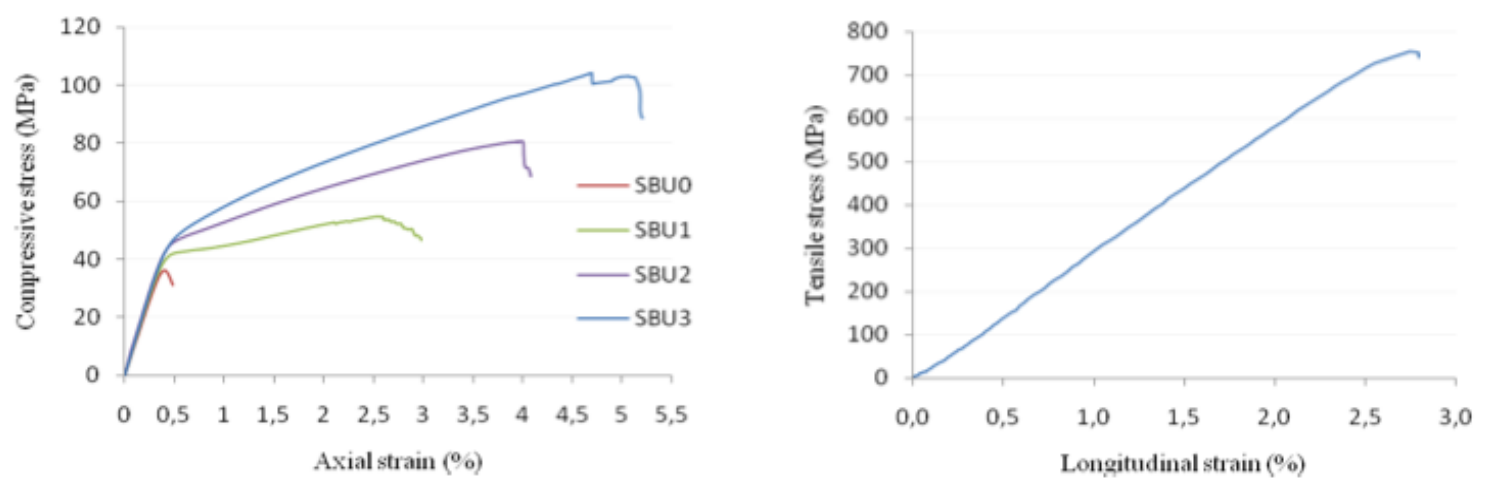

Figure 2.4: Stress-Strain curve for concrete specimen (Left) and Stress-Strain Curve for BFRP (Right)

\subsection{Summary}

Basalt FRP is an alternative FRP compared to carbon and glass FRP being used in the construction industry. BFRP has many advantages similar to both glass and carbon FRP. It has the potential to economically substitute the GFRP. Therefore, it is essential to study the behavior of concrete members reinforced with basalt FRP. 


\section{Basalt FRP Bars}

\subsection{Introduction}

Tests were conducted on basalt FRP bars to determine their properties for designing concrete members, especially beams. All of the tests conducted are described briefly with the equipment, procedures and results. Test methods used are as per AASHTO and ACI specifications.

Short-term tests used in this research are:

1. Tension Test (section 3.2)

2. Compression Test (section 3.3)

3. Shear Test (section 3.4)

4. Inter-Laminar Shear Test (section3.5)

5. Bond Test (section 3.6)

6. Burn-off Test (section 3.7)

7. Differential Scanning Calorimeter (DSC) (section 3.8)

8. Moisture absorption (section 3.9)

\subsection{Tension Test}

This test involves tensile loading up to failure to determine ultimate strength and stiffness of BFRP bar using data from load cell, strain gage data, and data acquisition system.

\subsubsection{Terminology}

a) Test section: The portion of a specimen to be tested between the anchoring sections of the test 
specimen.

(b) Grip length (anchoring section): The end part of the test specimen where an anchorage is fitted to transmit the load from the testing machine to the test section.

(c) Gage length: The distance between two gage points on the test section providing a reference length to the test specimen.

(d) Anchorage: Device fitted to the anchoring section of a test specimen to transmit loads from the testing machine to the test specimen.

(e) Tensile capacity: The tensile load at the failure of the test specimen.

(f) Guaranteed tensile capacity: Guaranteed value for the tensile capacity corresponding to the average value -3 times standard deviation.

\subsubsection{Specimen Preparation}

a) Preparation: For specimen preparation, care was taken such that specimen was not subjected to any additional damage such as cutting, abrading etc. All deformation, heating, outdoor exposure to ultraviolet light etc., that cause change in the material properties of the test specimen were avoided.

b) Test section length \& Grip length: A test section length of about 20 inch was adopted with a grip length of 10 inch for \#4 BFRP bars and \#5 BFRP bars.

c) Anchorages (Grips): Schedule 80 Steel pipes of appropriate diameter and length were split and bonded to each end of BFRP rebar using Pliogrip, a commercially available resin. The resin was allowed to cure for a minimum of 24 hours, before the specimens were tested.

d) Number of Specimens: Minimum number of specimens tested was three for each diameter bar. 


\subsubsection{Test Equipment}

Tension specimens were tested on a universal testing machine with maximum load capacity of 220 kips. A computerized data acquisition system was used to automatically record the load and strain for data analysis. (Figure 3.1)

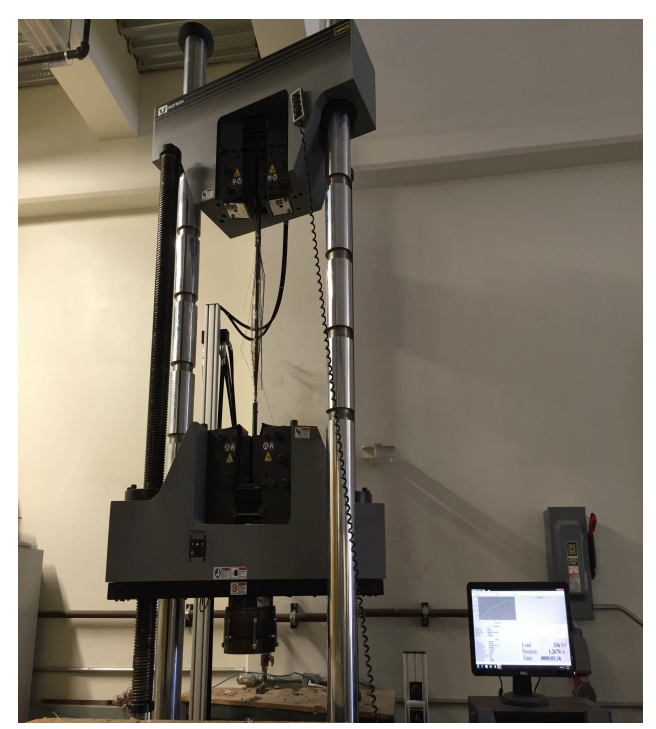

Figure 3.1: Tension Testing of BFRP Bar

\subsubsection{Test Method}

(a) Strain Gage: Strain gage was placed at the center of the test specimen and used to determine the Elastic modulus.

(b) Mounting: Care was taken to ensure the longer axis of test specimen split grip opening coincided with the imaginary line joining the two end anchors fitted to the testing machine.

(c) Loading Rate: The applied rate of loading for the tension test specimen was between 7.5 kip per minute to achieve failure between 2 to 5 minutes.

(d) Loading: The load was applied until tensile failure, and the measurements were recorded 
until the load reaches at least $60 \%$ of the tensile capacity or the guaranteed tensile capacity.

\subsubsection{Calculation}

The material properties of BFRP bar were calculated on the basis of proper tension failure of the test specimen.

(a) Tensile Stress, $\sigma$ : The tensile stress was calculated according to Eq. (3.1),

$$
\sigma=\mathrm{F} / \mathrm{A}
$$

Where,

$$
\begin{aligned}
& \sigma=\text { Tensile stress (ksi) } \\
& \mathrm{F}=\text { Load at the calculated stress (kip) } \\
& \mathrm{A}=\text { Cross sectional area of test specimen }\left(\mathrm{in}^{2}\right)-\text { based on the manufacturer die } \\
& \text { diameter }
\end{aligned}
$$

(b) Strain, $\varepsilon$ : Load and strain were recorded from the strain gauge that is attached on test specimen. Data acquisition system was used to collect data.

(c) Stiffness, E (Young's modulus): In order to get stiffness, stress collected in part (a) and the corresponding strain in part (b) were plotted to get stress-strain curve. The slope of the curve gives the stiffness.

\subsubsection{Test Results}

\section{Test and Specimen Details}

- Surface texture - Sand Coated

- Diameter of bars tested - 0.500" (\#4), 0.625” ((\#5) 
- Length of test specimen $\geq 41$ "

- Grip length of each end (minimum) $\geq 10$ "

- Number of specimens - Minimum of 3 for each test type

- Strain was measured at the center of the specimen using strain gauge

- Stiffness values were calculated using stress-strain plots
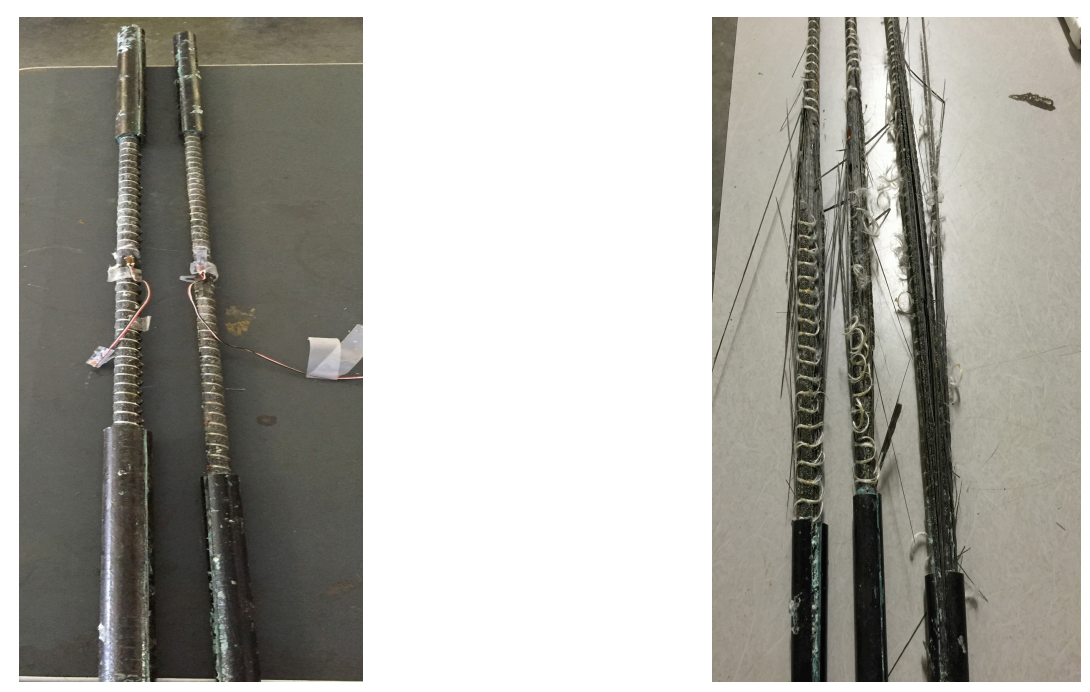

Figure 3.2: \#4 and \#5 BFRP Specimen before (left) and after (Right) Tension Test

\section{Tension Test Results}

Table 3.1: Tensile Test Result for \#4 Sand Coated BFRP Bar

\begin{tabular}{|c|c|c|c|c|}
\hline \multirow{2}{*}{$\#$} & Diameter & Max Stress & Stiffness & \multirow{2}{*}{ Failure } \\
\cline { 2 - 4 } & $(\mathrm{in})$ & $(\mathrm{ksi})$ & $(\mathrm{Msi})$ & \\
\hline 1 & 0.500 & 134.28 & - & At center \\
\hline 2 & 0.500 & 102.88 & 7.41 & At center \\
\hline 3 & 0.500 & 118.56 & 7.87 & At center \\
\hline Average & & 118.57 & 7.64 & \\
\hline std dev & & 12.82 & 0.23 & \\
\hline$\%$ & & 10.81 & 2.99 & \\
\hline
\end{tabular}


Table 3.2: Tensile Test Result for \#5 Sand Coated BFRP Bar

\begin{tabular}{|c|c|c|c|c|}
\hline \multirow{2}{*}{$\#$} & Diameter & Max Stress & Stiffness & \multirow{2}{*}{ Failure } \\
\cline { 2 - 4 } & $($ in) & $(\mathrm{ksi})$ & $(\mathrm{Msi})$ & \\
\hline 1 & 0.625 & 117.02 & 7.03 & At center \\
\hline 2 & 0.625 & 96.36 & 6.44 & At center \\
\hline 3 & 0.625 & & & \\
\hline Average & & 106.69 & 6.74 & \\
\hline std dev & & 10.33 & 0.29 & \\
\hline$\%$ & & 9.68 & 4.32 & \\
\hline
\end{tabular}

\section{Discussion of Test Results}

Tension test results are summarized and discussed as follows:

- Stress and Stiffness: As shown from results, \#4 diameter bars have an average stress of $11.14 \%$ higher than \#5 diameter bars, which is because of the shear lag in larger diameter bars. The average stiffness of \#4 diameter bars is $28.73 \%$ more than \#5 diameter bars (11.14).

- $\quad$ Failure mode $=$ Failure mode in all the specimens was observed at the center with fibers splitting on the outer layer. At the end of the test, fibers were split into conical mesh pattern as shown in Figure 3.2.

- \#4 BFRP Bar

$\Rightarrow$ Average tensile stress $=118.57 \pm 12.82 \mathrm{ksi}($ Std. dev. was $10.81 \%$ of avg. value $)$

$\Rightarrow$ Average Stiffness $=7.64 \pm 0.23 \mathrm{Msi}$ (Std. dev. was $2.99 \%$ of avg. value) 
- \#5 BFRP Bar

$\Rightarrow$ Average tensile stress $=106.69 \pm 10.33 \mathrm{ksi}$ (Std. dev. was $9.68 \%$ of avg. value)

$\Rightarrow$ Average Stiffness $=6.74 \pm 0.392$ Msi (Std. dev. was $4.32 \%$ of avg. value)

\subsection{Compression Test}

This test involves compressive loading up to failure to determine ultimate strength and stiffness of the bar using data from load cell, strain gage data, and data acquisition system.

\subsubsection{Terminology}

a) Test section: The portion of a specimen to be tested between the anchoring sections of the test specimen.

(c) Gage length: The distance between two gage points on the test section providing a reference length to the test specimen.

(e) Compressive capacity: The compressive load at the failure of the test specimen.

(f) Guaranteed compressive capacity: Guaranteed value for the compressive capacity corresponding to the average value -3 times standard deviation.

\subsubsection{Specimen Preparation}

e) Preparation: For specimen preparation, care was taken such that the specimen was not subjected to any additional deterioration such as cutting, abrading etc. All deformation, heating, outdoor exposure to ultraviolet light etc., that cause change in the material properties of the test specimen were avoided.

(a) Length: The length (h) of the test specimen was selected by using a length (h) to diameter 
ratio(d) of 2 .

$$
h / d=2
$$

(b) Number of Specimens: Minimum number of specimens tested was three for each diameter.

\subsubsection{Test Equipment}

Compression specimens were tested on a universal testing machine with a maximum load capacity of 220 kips. A computerized data acquisition system was used to automatically log in the load and strain for data analysis.

\subsubsection{Test Method}

a) Strain Gage: In order to determine the Elastic modulus of the test specimen, a strain gage was mounted at the center of the test section.

b) Loading Rate: loading rate for the compression tests was to achieve failure between 2 to 5 minutes.

c) Loading: The load was applied until failure, and the measurements were recorded until the load reached peak compressive capacity of the specimen.

\subsubsection{Calculation}

The material properties of BFRP bar were measured on the basis of proper compression failure of the test specimens.

(a) Compressive Stress, $\sigma$ : The compressive stress was calculated according to Eq. (3.1),

$\sigma=\mathrm{F} / \mathrm{A}$

Where, 


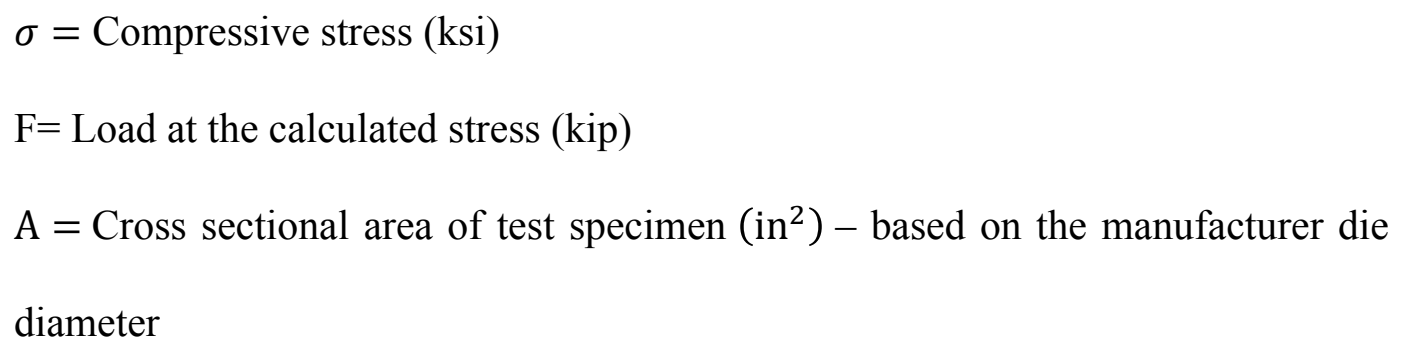

(b) Strain, $\varepsilon$ : Load and strain were recorded from the strain gauge that is attached on test specimen. Data acquisition was used to collect data.

(c) Stiffness, E (Young's modulus): In order to get stiffness, stress collected in part (a) and the corresponding strain in part (b) were plotted to get stress-strain curve. The slope of the curve gives the stiffness.

\subsubsection{Test Results}

\section{Test and Specimen Details}

- Surface texture - Sand Coated

- Diameter of bars tested - 0.500” (\#4), 0.625” ((\#5)

- Height of test specimens - 1", 1.25", respectively

- Number of specimens - Minimum of 3 for each bar diameter

- Stiffness values were calculated using stress-strain plots 

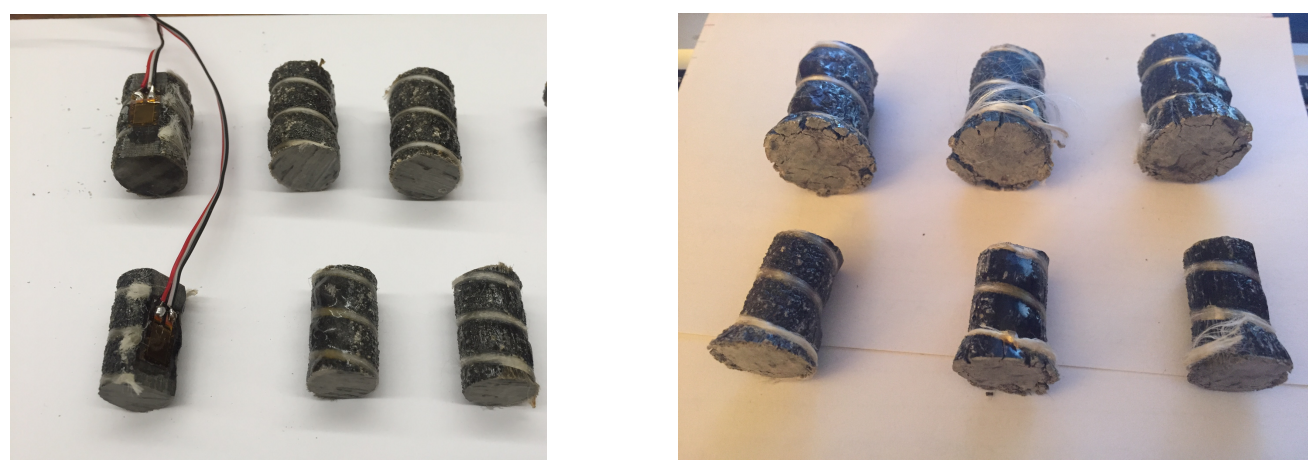

Figure 3.3: Failure Mode of Compression Test Specimens for BFRP Bars

\section{Compression Test Results}

Table 3.3: Compression Test Results for \#4 Sand Coated BFRP Bar

\begin{tabular}{|c|c|c|c|c|}
\hline \multirow{2}{*}{ \# } & Dia & Max Stress & Stiffness & \multirow{2}{*}{ Failure } \\
\hline & (in) & (ksi) & (Msi) & \\
\hline 1 & 0.5 & 53.73 & 7.3 & \multirow{6}{*}{$\begin{array}{c}\text { Crushing of } \\
\text { bar at } \\
\text { bottom end } \\
\text { of the } \\
\text { vertically } \\
\text { positioned } \\
\text { bar }\end{array}$} \\
\hline 2 & 0.5 & 67.10 & 7.12 & \\
\hline 3 & 0.5 & 65.88 & 7.56 & \\
\hline Average & & 62.24 & 7.33 & \\
\hline std dev & & 6.04 & 0.18 & \\
\hline$\%$ & & 9.70 & 2.47 & \\
\hline
\end{tabular}

Table 3.4: Compression Test Results for \#5 Sand Coated BFRP Bar

\begin{tabular}{|c|c|c|c|c|}
\hline \multirow{2}{*}{$\#$} & Dia & Max Stress & Stiffness & \multirow{2}{*}{ Failure } \\
\hline & (in) & (ksi) & (Msi) & \\
\hline 1 & 0.625 & 65.68 & 5.7 & \multirow{6}{*}{$\begin{array}{l}\text { Crushing of } \\
\text { bar at } \\
\text { bottom end } \\
\text { of the } \\
\text { vertically } \\
\text { positioned } \\
\text { bar }\end{array}$} \\
\hline 2 & 0.625 & 74.49 & 7.56 & \\
\hline 3 & 0.625 & 68.34 & 7.34 & \\
\hline Average & & 69.50 & 6.87 & \\
\hline std dev & & 3.69 & 0.83 & \\
\hline$\%$ & & 5.31 & 12.08 & \\
\hline
\end{tabular}




\section{Discussion of Test Results}

Compression test results are summarized and discussed as follows:

- Stress and Stiffness: The average compressive stress of \#4 and \#5 BFRP bars are 30$40 \%$ less than the average tensile stress. Average Stiffness for \#4 BFRP bars was $8.28 \mathrm{ksi}$ and 8.74 ksi for \#5 BFRP bars.

- Failure Mode: Failure mode in all specimens was observed to be buckling of fibers and separation of fibers from resin.

- \#4 BFRP Bar

$\Rightarrow$ Average compressive stress $=62.24 \pm 6.04 \mathrm{ksi}($ Std. dev. was $9.70 \%$ of avg. value $)$

$\Rightarrow$ Average compressive stiffness $=7.33 \pm 0.18 \mathrm{Msi}$ (Std. dev. was $2.47 \%$ of avg. value)

- \#4 BFRP Bar

$\Rightarrow$ Average compressive stress $=69.50 \pm 3.69 \mathrm{ksi}($ Std. dev. was $5.31 \%$ of avg. value $)$

$\Rightarrow$ Average compressive stiffness $=6.87 \pm 0.83 \mathrm{Msi}$ (Std. dev. was $12.08 \%$ of avg. value)

\subsection{Shear Test}

Single and double shear tests were conducted to determine the ultimate shear strength of BFRP bar.

\subsubsection{Terminology}

a) Test section: The portion of a specimen to be tested between the anchoring sections.

b) Anchoring section: The end parts of the test specimen where the test specimen is anchored to 
the shear apparatus.

c) Shear Apparatus: Apparatus used to conduct the shear test as shown in Figure 3.4

d) Anchor Length: The length of the FRP bar anchored to the shear fixture on each end of the bar (one end in case of single shear test)

e) Cutting tool: A device, which is used to transfer the load from the testing machine to the test specimen.

f) Single Shear Test: In this test, only one cross-section of the bar was tested in shear.

g) Double Shear Test: In this test, two cross-sections of the bar were tested in shear.

\subsubsection{Specimen Preparation}

a) Preparation: For specimen preparation, care was taken such that specimen was not subjected to any additional damage such as cutting, abrading etc. All deformation, heating, outdoor exposure to ultraviolet light etc., that cause change in the material properties of the test specimen were avoided.

b) Test section length \& Anchor length: Shear tests were performed with $1 / 2$ " cutting tool. The remaining length of the bar was anchored (one end for single shear test and both ends for double shear test). The total lengths of test specimens including the anchor length for single shear test and double shear test were 5 in and 8 in, respectively.

c) Anchorages: Bolts were used to anchor the specimen to the shear fixture to minimize bending effects.

d) Cutting Tool: Cutting tools of $1 / 2$ " width was used.

e) Number of Specimens: Minimum number of specimens tested for each diameter bar was three. 


\subsubsection{Test Equipment}

Single and double shear test specimens were tested using the equipment shown in Figure 3.4.

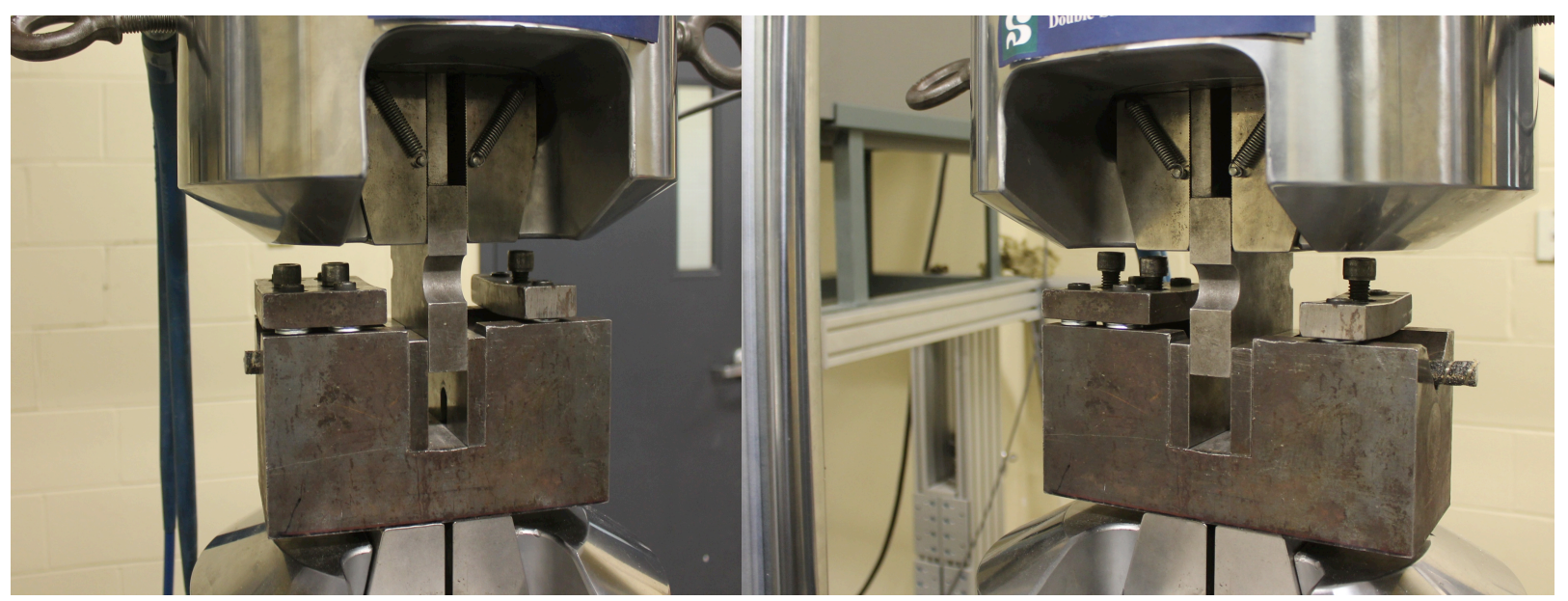

Figure 3.4: Single Shear Test Equipment

\subsubsection{Test Method}

(a) Shear Apparatus: The shear testing apparatus was constructed so that a rod-shaped test specimen is sheared on two planes more or less simultaneously by two blades (edges) converging along the faces perpendicular to the axis direction of the test specimen.

(b) Mounting: The test specimen was mounted at the center of the shear apparatus, touching the cutting tool such that no gap was visible between the contact surface of the cutting tool and the test specimen.

(c) Loading Rate: The applied rate of loading for the tension test specimen was between 3-7 ksi per minute.

(d) Loading: The load was applied until shear failure, and the measurements were recorded. 


\subsubsection{Calculation}

Shear stress of specimens was calculated according to Eq. (3.2)

$\tau=\mathrm{P} /(\mathrm{n} \mathrm{A})$

Where,

$\tau=$ Shear stress $(\mathrm{ksi})$

$P=$ Shear failure load (kip)

$\mathrm{A}=$ Cross sectional area of test specimen $\left(\mathrm{in}^{2}\right)$ - based on the manufacturer die diameter.

$\mathrm{n}=1,2$ for single shear and double shear respectively.

\subsubsection{Test Results}

\section{Single Shear Test and Specimen Details}

- Surface texture - Sand Coated

- Diameter of bars tested - 0.500" (\#4), 0.625” ((\#5)

- Length of test specimen -5 " each

- Cutting tool width-1/2"

- Number of specimens - Minimum of three for each bar diameter

- Specimen was anchored at one end

\section{Double Shear Test and Specimen Details}

- Surface texture - Sand Coated

- Diameter of bars tested - 0.500" (\#4), 0.625” ((\#5)

- Length of test specimen -8 " each 
- Cutting tool width- 1/2"

- Number of specimens - Minimum of three for each bar diameter

- Specimen was anchored at both end

\section{Shear Test Results}

Table 3.5: Single and Double Shear Test Results for \#4 Sand Coated BFRP Bar

\begin{tabular}{|c|c|c|c|}
\hline \multirow{2}{*}{$\#$} & Diameter & Single Shear Stress & Double Shear Stress \\
\cline { 2 - 4 } & $(\mathrm{in})$ & $(\mathrm{ksi})$ & $(\mathrm{ksi})$ \\
\hline 1 & 0.500 & 26.36 & 28.30 \\
\hline 2 & 0.500 & 25.84 & 31.38 \\
\hline 3 & 0.500 & 26.15 & 29.02 \\
\hline Average & & 26.12 & 29.57 \\
\hline std dev & & 0.26 & 1.31 \\
\hline$\%$ & & 0.99 & 4.44 \\
\hline
\end{tabular}

Table 3.6: Single and Double Shear Tests Result for \#5 Sand Coated BFRP Bar

\begin{tabular}{|c|c|c|c|}
\hline \multirow{2}{*}{$\#$} & Diameter & Single Shear Stress & Double Shear Stress \\
\cline { 2 - 4 } & $(\mathrm{in})$ & $(\mathrm{ksi})$ & $(\mathrm{ksi})$ \\
\hline 1 & 0.625 & 24.24 & 29.70 \\
\hline 2 & 0.625 & 23.91 & 27.86 \\
\hline 3 & 0.625 & 23.72 & 26.30 \\
\hline Average & & 23.96 & 27.95 \\
\hline std dev & & 0.16 & 1.39 \\
\hline$\%$ & & 0.69 & 4.97 \\
\hline
\end{tabular}

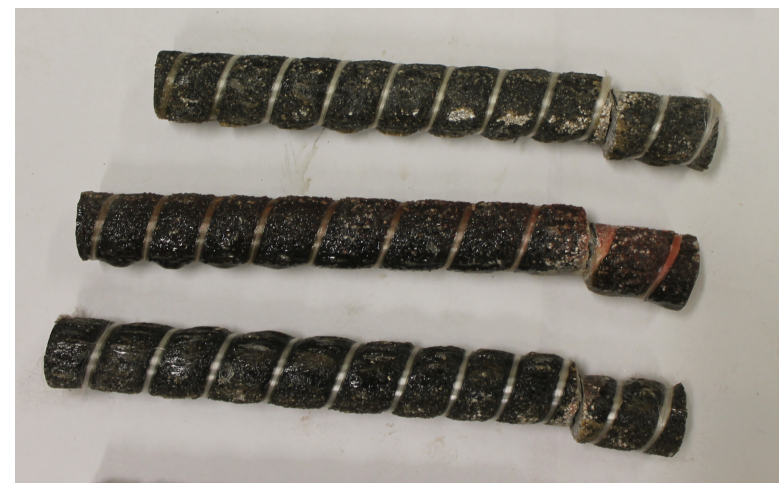

Figure 3.5: Single Shear Tests of BFRP Bar Specimens 


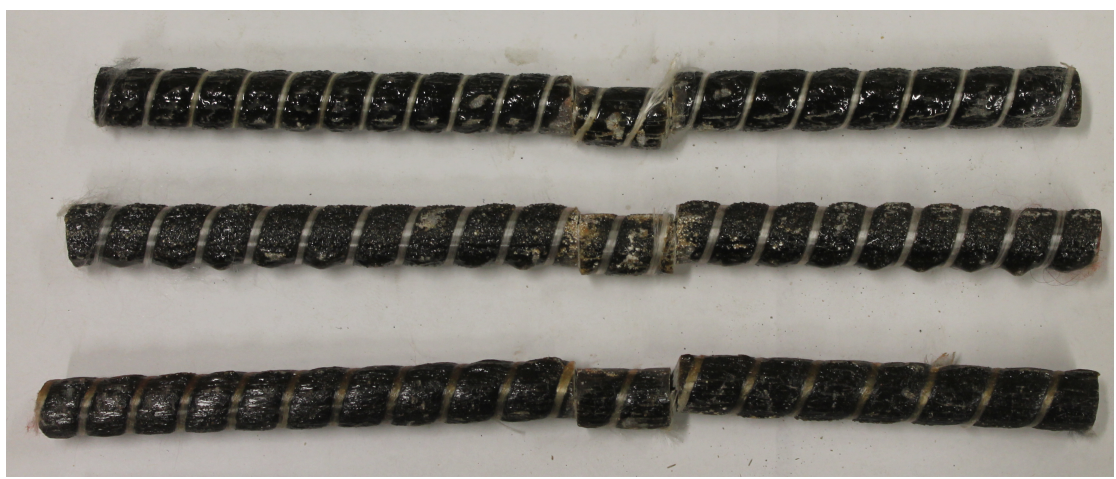

Figure 3.6: Double Shear Tests of BFRP Bar Specimens

\section{$>$ Discussion of Test Results}

Single and double shear test results are summarized and discussed as follows:

- Failure Mode: All BFRP bar specimens failed at the shearing edge of the cutting tool

- As shown from results, shear stress from single shear test are $10-12 \%$ less than double shear test results due to the effect of bending in single shear test. It should be noted that single shear specimens are supported as cantilever specimens.

- \#4 BFRP bar

$\Rightarrow$ Average single shear stress $=26.12 \pm 0.26 \mathrm{ksi}$ (Std. dev. was $0.99 \%$ of avg. value)

$\Rightarrow$ Average double shear stress $=29.57 \pm 1.31 \mathrm{ksi}($ Std. dev. was $4.44 \%$ of avg. value)

- \#5 BFRP bar

$\Rightarrow$ Average single shear stress $=23.96 \pm 0.16 \mathrm{ksi}$ (Std. dev. was $0.69 \%$ of avg. value)

$\Rightarrow$ Average double shear stress $=27.95 \pm 1.39 \mathrm{ksi}$ (Std. dev. was $4.97 \%$ of avg. value) 


\subsection{Inter-Laminar Shear Test}

This test was done to determine the inter-laminar shear strength of BFRP bar.

\subsubsection{Test Procedure}

- Specimens were cut to 3 " in length

- Specimens were placed on the horizontal shear test fixture.

- Load was applied perpendicular to the BFRP bar until breakage. (See Figure 3.7)

\subsubsection{Test Equipment}

Figure 3.7 shows the equipment used for inter-laminar shear test.
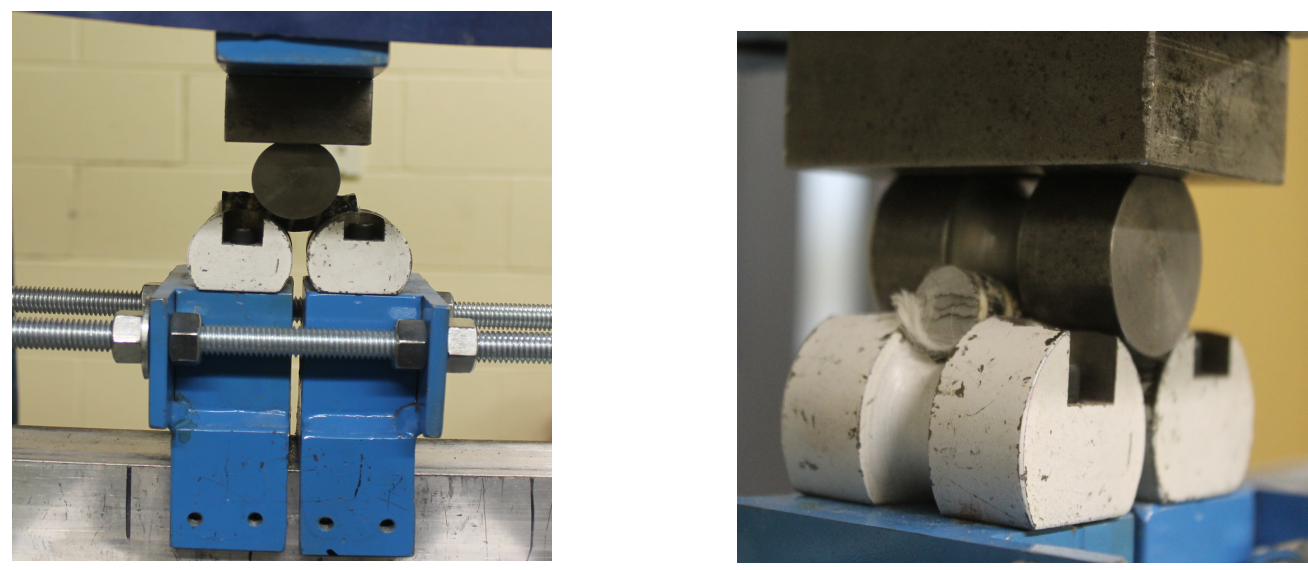

Figure 3.7: Inter-Laminar Shear Test Equipment

\subsubsection{Calculation}

The shear strength for the inter-laminar shear was calculated using the following equation:

$\mathrm{S}=\frac{0.849 \mathrm{P}}{\mathrm{d}^{2}} * 1000$

Where,

$\mathrm{S}=$ Shear strength (MPa) 


$$
\begin{aligned}
& \mathrm{P}=\text { Ultimate Load }(\mathrm{kN}) \\
& \mathrm{d}=\text { Diameter }(\mathrm{mm})
\end{aligned}
$$

\subsubsection{Test Results}

Table 3.7: Inter-Laminar Shear Test Result for \#4 Sand Coated BFRP bar

\begin{tabular}{|c|c|c|c|}
\hline \multirow{2}{*}{$\#$} & Dia & Load & $\begin{array}{c}\text { Inter-Laminar } \\
\text { Shear Strength }\end{array}$ \\
\cline { 2 - 4 } & in (mm) & kips $(\mathrm{kN})$ & ksi (Mpa) \\
\hline 1 & $0.500(13)$ & $2.23(9.93)$ & $7.58(52.37)$ \\
\hline 2 & $0.500(13)$ & $2.12(9.42)$ & $7.19(49.59)$ \\
\hline 3 & $0.500(13)$ & $2.24(9.98)$ & $7.62(52.53)$ \\
\hline 4 & $0.500(13)$ & $2.12(9.45)$ & $7.21(49.74)$ \\
\hline Average & & & $7.40(51.03)$ \\
\hline std dev & & & $0.20(1.37)$ \\
\hline$\%$ & & & 3 \\
\hline
\end{tabular}

Table 3.8: Inter-Laminar Shear Test Result for \#5 Sand Coated BFRP bar

\begin{tabular}{|c|c|c|c|}
\hline \multirow{2}{*}{$\#$} & Dia & Load & $\begin{array}{c}\text { Inter-Laminar } \\
\text { Shear Strength }\end{array}$ \\
\cline { 2 - 4 } & in $(\mathrm{mm})$ & kips $(\mathrm{kN})$ & ksi $(\mathrm{Mpa})$ \\
\hline 1 & $0.625(16)$ & $3.41(15.19)$ & $7.43(51.17)$ \\
\hline 2 & $0.625(16)$ & $3.98(17.71)$ & $8.65(59.66)$ \\
\hline 3 & $0.625(16)$ & $3.30(14.68)$ & $7.17(49.45)$ \\
\hline 4 & $0.625(16)$ & $2.65(11.78)$ & $5.75(39.68)$ \\
\hline Average & & & $7.25(49.99)$ \\
\hline std dev & & & $1.03(7.10)$ \\
\hline$\%$ & & & 14 \\
\hline
\end{tabular}
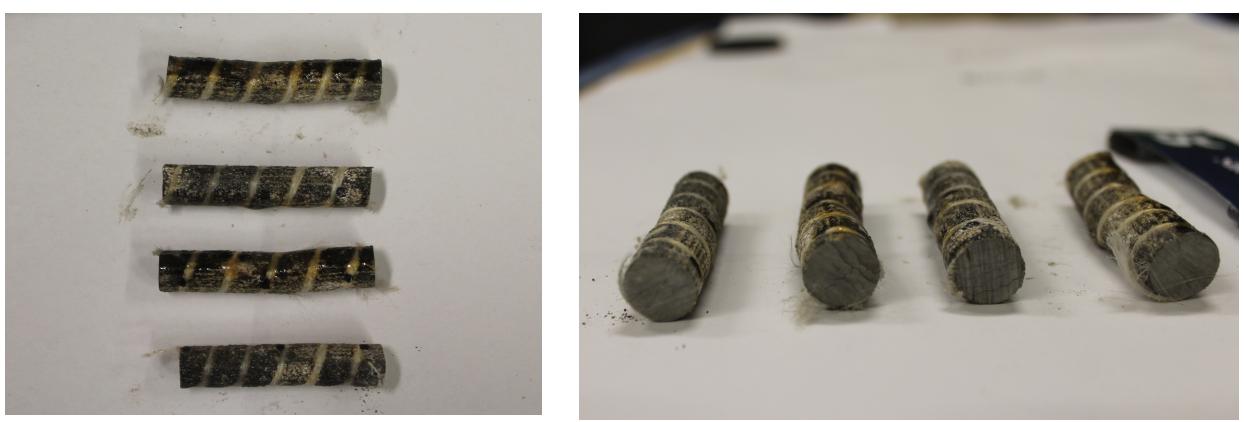

Figure 3.8: Inter-laminar Shear Test Specimens 


\section{Discussion of Test Results}

Inter-laminar shear test results are summarized and discussed as follows:

Failure Mode: All BFRP bar specimens were permanently deformed at the location of load application (mid-section) and fiber failure was noticed.

$\Rightarrow$ Average inter-laminar shear stress (\#4 BFRP bar) $=7.40 \pm 0.20 \mathrm{ksi}$ (Std. dev. was $3 \%$ of avg. value)

$\Rightarrow$ Average inter-laminar shear stress (\#5 BFRP bar) $=7.25 \pm 1.03 \mathrm{ksi}($ Std. dev. was 14 $\%$ of avg. value)

\subsection{Bond Test}

Pull-out bond strength of GFRP bars: Preliminary evaluations indicate that the pullout bond strength of sand coated BFRP bars is similar to those of other sand-coated FRP bars. Previous studies have shown that the sand coated FRP bars have bond-stress in the range of 1700-2300 psi as compared to about 1700 psi for steel bars. These BFRP bars are sand coated and a comprehensive short- and long-term bond strength study will be carried out in the future.

\subsection{Burn-off Test}

Fiber volume fraction is the volume of fiber in cured specimen. This test is performed to determine the mass content of resin and fiber. Fiber volume fraction of the bar is determined from the resin burn-off test as per ASTM D 2584-68.

\subsubsection{Test Procedure}

Procedure of burn-off test is described as follow: 
1. BFRP bar specimens were cut to a length of $1.5 "$ and placed in crucible and weighed.

2. The crucible was placed in an oven at $650^{\circ} \mathrm{C}$ overnight and burned.

3. The crucible was removed from oven and cooled.

4. After the crucible was cooled, specimen was weighed.

5. Fiber volume fraction was calculated

\subsubsection{Test Results}

$V_{f}=\frac{v_{\text {fiber }}}{v_{c}}$

Where,

$V_{f}=$ Fiber volume fraction

$v_{\text {fiber }}=$ Fiber volume

$v_{c}=$ FRP Composite volume
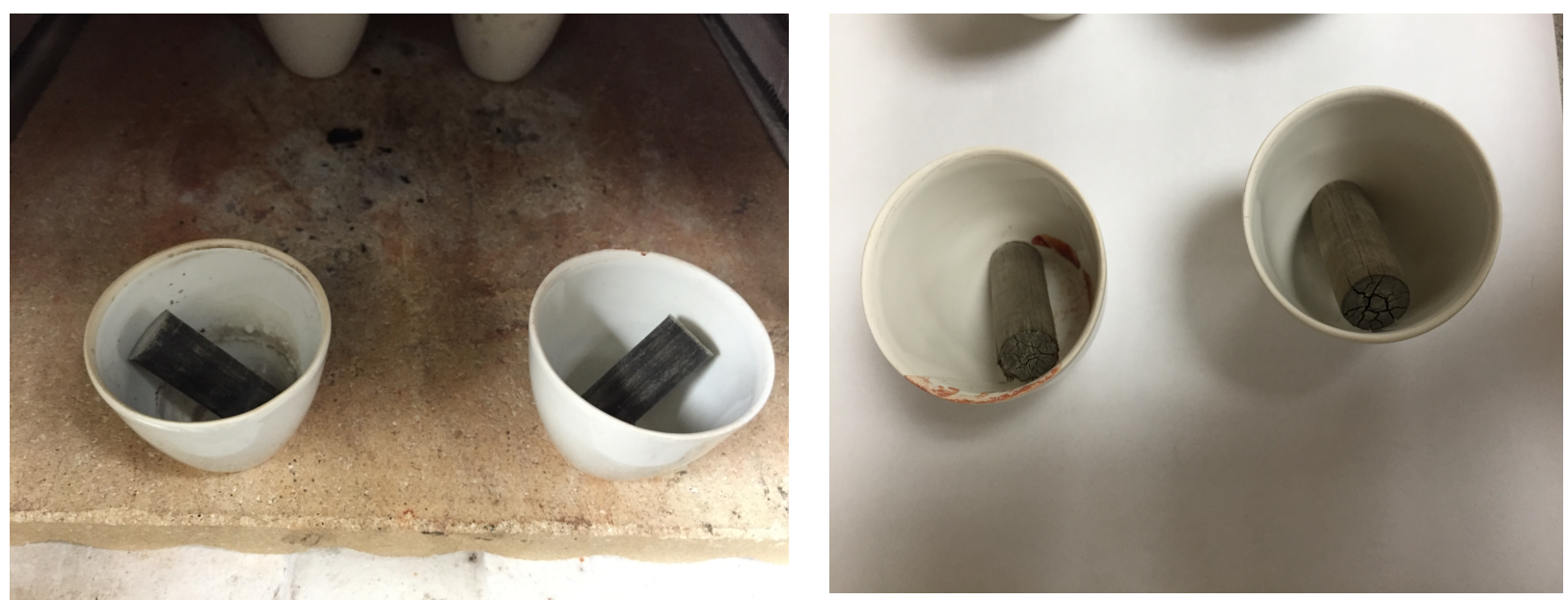

Figure 3.11: BFRP Specimen Before and After Burn-off Test 
Table 3.11: Results of Burn-off Tests for \#4 and \#5 BFRP Bar

\begin{tabular}{|c|c|c|c|c|c|c|c|c|c|}
\hline \multirow{2}{*}{ No. } & \multirow{2}{*}{$\begin{array}{c}\text { Bar } \\
\text { size }\end{array}$} & Dia (in) & $m_{-}$crucible & $\begin{array}{c}\text { (Crucible+ } \\
\text { BFRP) } \\
\text { weight }\end{array}$ & $\begin{array}{c}\text { BFRP } \\
\text { weight }\end{array}$ & $\begin{array}{c}\text { (Crucible+ } \\
\text { BFRP) } \\
\text { weight }\end{array}$ & $\begin{array}{c}\text { Weight of } \\
\text { Fibers }\end{array}$ & $\begin{array}{c}\text { Volume } \\
\text { of Fiber }\end{array}$ & $\begin{array}{c}\text { Fiber } \\
\text { Volume } \\
\text { Fraction }\end{array}$ \\
\cline { 3 - 11 } & (in) & $\mathrm{g}$ & $\begin{array}{c}\text { (Before } \\
\text { test) }\end{array}$ & $\mathrm{g}$ & $\begin{array}{c}\text { (After) } \\
\text { test) }\end{array}$ & $\mathrm{g}$ & $\mathrm{cm}^{3}$ & & \\
\hline 1 & $\# 4$ & 0.438 & 32.000 & 40.548 & 8.54 & 38.954 & 6.950 & 2.623 & $70.97 \%$ \\
\hline 2 & $\# 4$ & 0.438 & 36.910 & 45.417 & 8.51 & 43.845 & 6.940 & 2.619 & $70.87 \%$ \\
\hline 3 & $\# 4$ & 0.438 & 31.689 & 40.503 & 8.82 & 38.852 & 7.168 & 2.705 & $73.20 \%$ \\
\hline & & & & & & & & Average & $71.68 \%$ \\
\hline 4 & $\# 5$ & 0.516 & 31.680 & 42.836 & 11.150 & 40.866 & 9.182 & 3.465 & $67.41 \%$ \\
\hline 5 & $\# 5$ & 0.516 & 33.170 & 43.822 & 10.660 & 41.919 & 8.754 & 3.303 & $64.27 \%$ \\
\hline 6 & $\# 5$ & 0.516 & 33.165 & 45.104 & 11.940 & 43.001 & 9.836 & 3.712 & $72.21 \%$ \\
\hline
\end{tabular}

Following density and volumes of FRP bar were used in the above calculation of Table 3.11.

- Density of basalt fiber $=2.65 \mathrm{~g} / \mathrm{cm}^{3}$

- \#4 BFRP bar composite volume $=3.695 \mathrm{~cm}^{3}$

- $\quad \# 5$ BFRP bar composite volume $=5.140 \mathrm{~cm}^{3}$

BFRP bars were made of epoxy resin. Since the bars were sand coated; the outer surface cleaned of sand coating prior to testing by removing the sand particles.. BFRP specimens were 1.5 " in length, for both diameters of \#4 and \#5 bars. As shown in Table 3.11, fiber volume fraction of the epoxy BFRP is $71.68 \%$ for \#4 BFRP bar and $67.96 \%$ for \#5 BFRP bar, which indicates the right amount of bars to be used as reinforcement for concrete members. 


\subsection{Differential Scanning Calorimeter (DSC) Test}

DSC test was carried out to determine the glass transition temperature of basalt FRP bars. Glass transition temperature is the temperature at which resin changes from brittle region to soft, rubbery region (Differential Scanning Calorimeter ASTM D3418, ASTM E1356, ISO 11357)

\subsubsection{Test Procedure}

Steps used in DSC testing are summarized below:

1. Two aluminum pans were used to conduct DSC tests.

2. Small, very thin pieces of \#4 and \#5 BFRP bars weighing about 3-8 mg were cut.

3. 3-8 $\mathrm{mg}$ of specimen was placed in pan.

4. Another empty pan used as a reference to measure the temperature difference

5. BFRP specimen pan was placed next to the empty reference pan in the DSC equipment.

6. Temperature was increased at a rate of $20^{\circ} \mathrm{C}$ per second.

7. Heat flow verses temperature was plotted by the DSC software equipment.

\subsubsection{Test Equipment}

DSC test equipment is shown in Figure 3.12. 


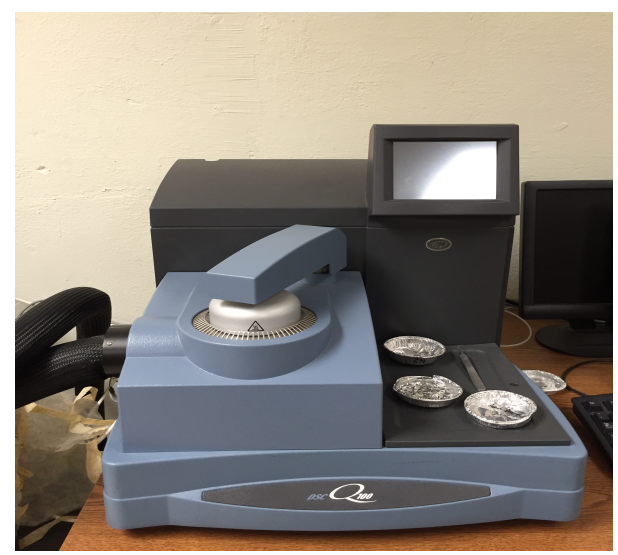

Figure 3.12: DSC Test Equipment

\subsubsection{Test Results}

\section{Test and Specimen Details:}

Epoxy resin matrix from both \#4 and \#5 BFRP bar specimens, were cut and used for conducting DSC test.

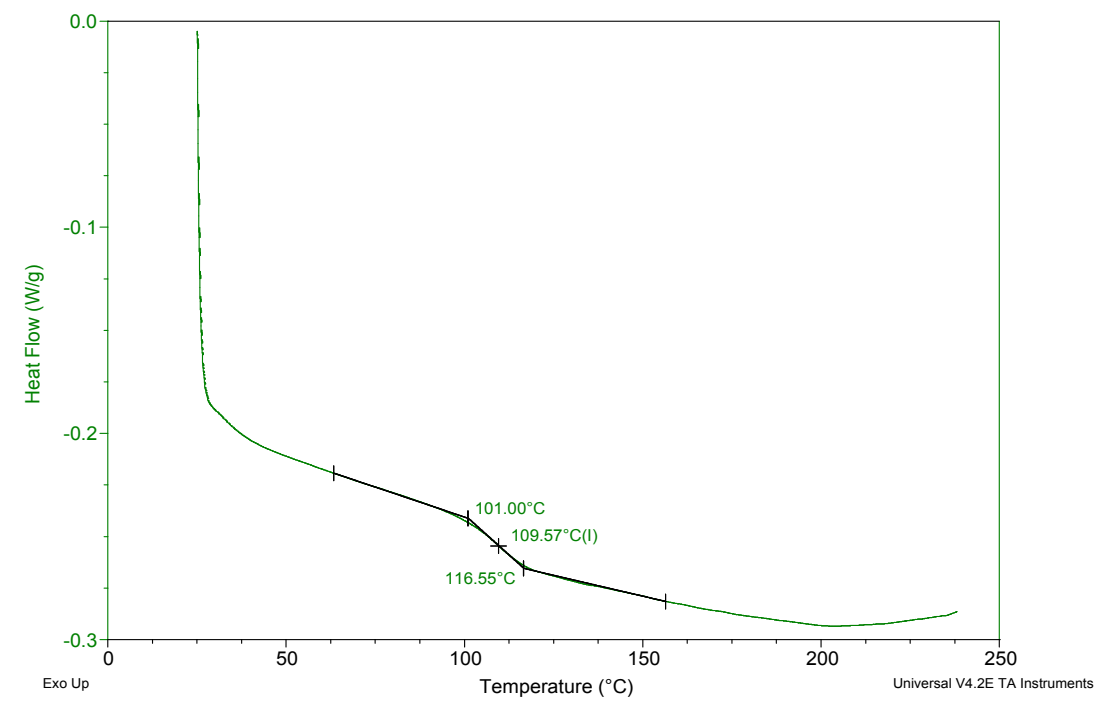

Figure 3.13: DSC Test Result of \#4 BFRP Specimen

- As shown from Figure 3.13, the glass transition temperature $\left(T_{g}\right)$ of $\# 4$ BFRP bar is $109^{\circ} \mathrm{C}$ where the specimen has cured uniformly. 


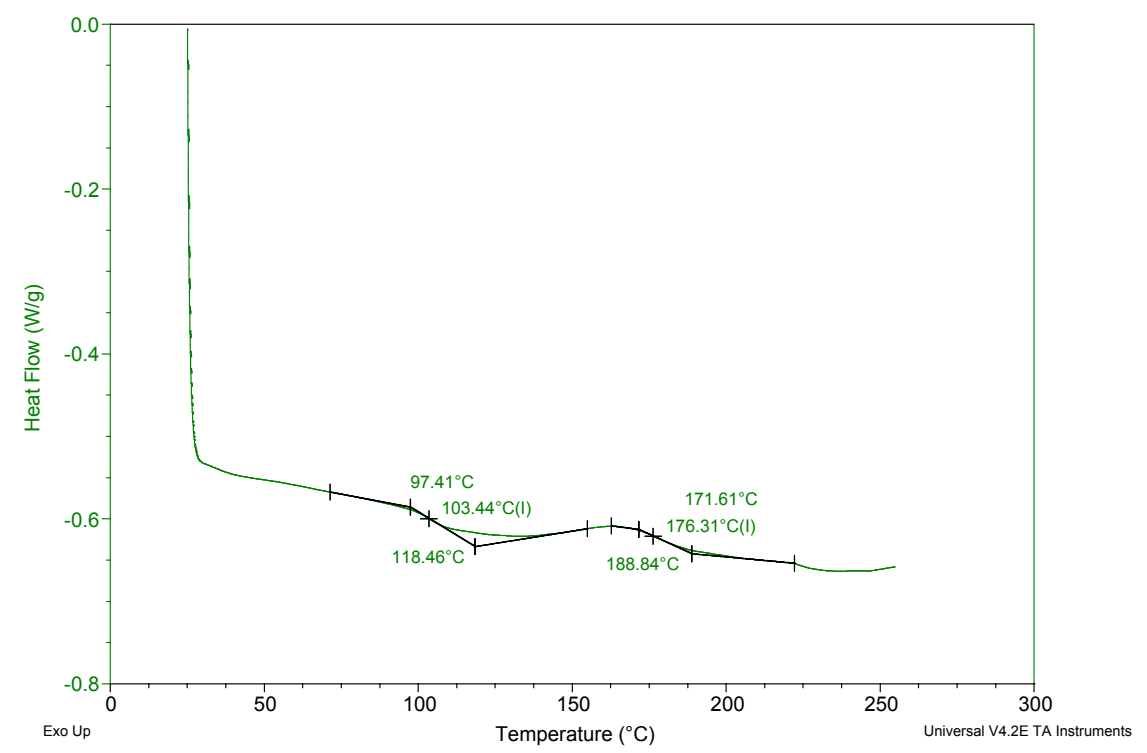

Figure 3.14: DSC Test Result of \#5 BFRP Specimen

- As shown from figure 3.14, \#5 BFRP bar has two glass transition temperatures $\left(T_{g}\right)$ of 104 ${ }^{\circ} \mathrm{C}$ and $176.31^{\circ} \mathrm{C}$, thus indicating that the specimen is not uniformly and fully cured.

\subsection{Moisture Absorption Test}

This test is done to determine the percentage of moisture gain in basalt FRP bars when it is immersed in water for 360 hours.

\subsubsection{Test Procedure}

- 2" long specimen were sealed at the ends using a thin coat of polyurethane resin and cured.

- Specimens were immersed in a glass cup.

- Specimens were monitored for moisture gain over a duration of 360 hours. 


\subsubsection{Test Result}

Table 3.12 and Figure 3.15-16 summarize of moisture gain in BFRP bars.

Table 3.12: Maximum Moisture (Weight) gain of BFRP Bars

\begin{tabular}{|l|c|c|c|}
\hline & 0 Hour & 360 Hours & \multirow{2}{*}{ \% Gain } \\
\cline { 2 - 3 } & $(\mathrm{g})$ & $(\mathrm{g})$ & \\
\hline \#4 Sand Coated BFRP & 14.1323 & 14.1673 & 0.241 \\
\hline \#5 Sand Coated BFRP & 22.6184 & 22.6736 & 0.244 \\
\hline
\end{tabular}

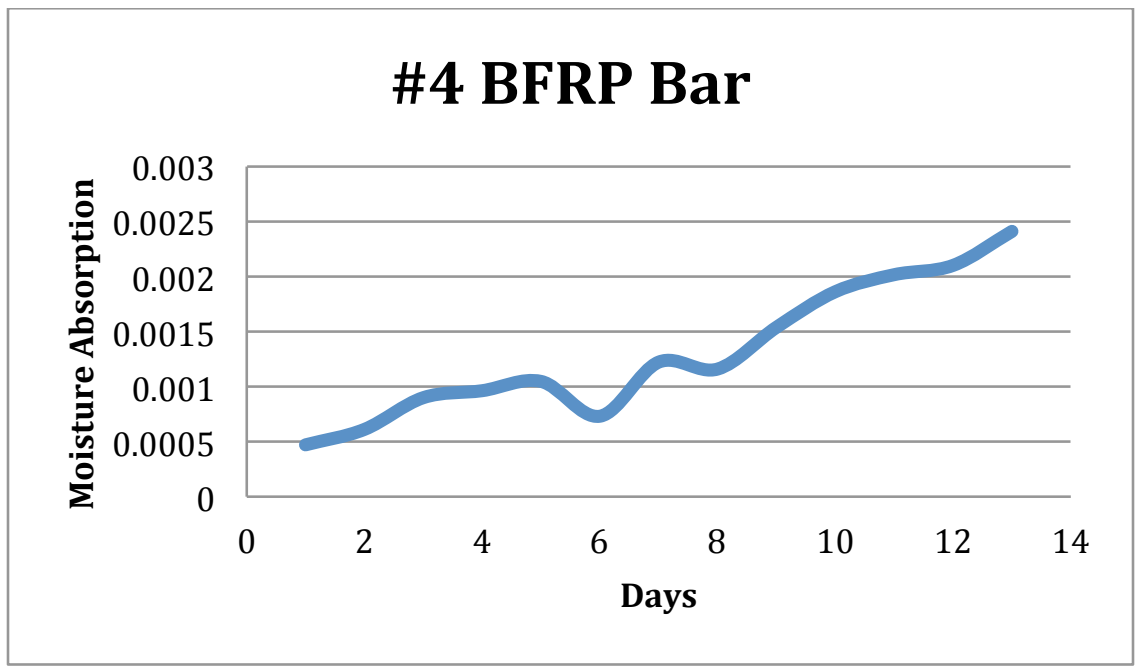

Figure 3.15: Moisture Absorption in \#4 Sand Coated BFRP Bars 


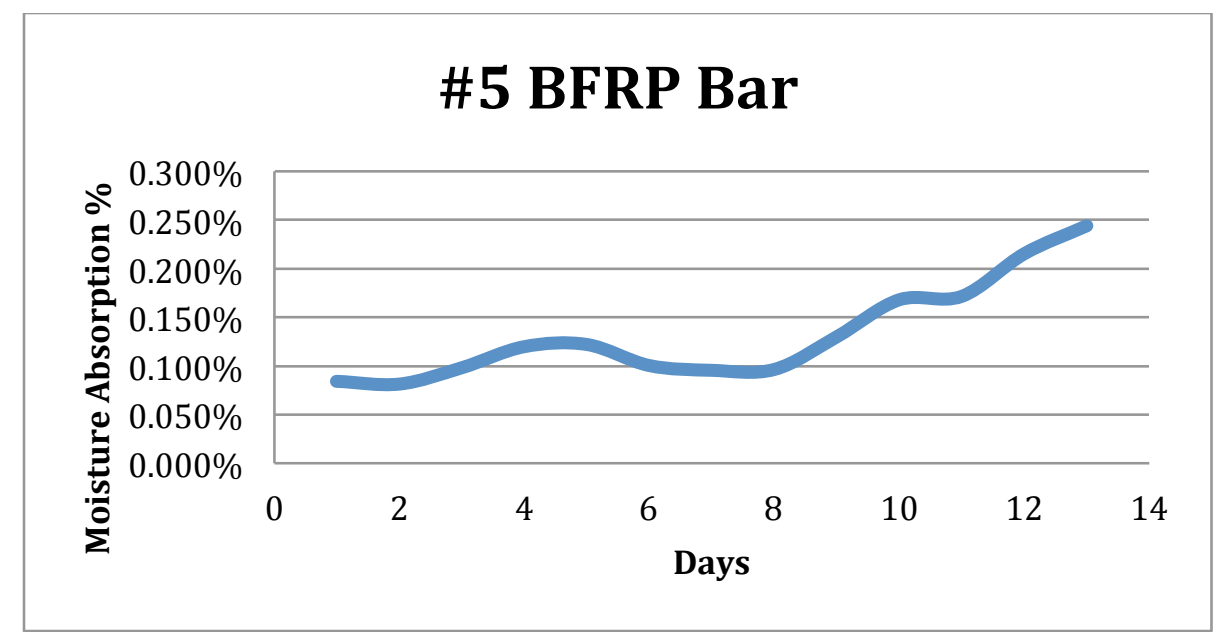

Figure 3.16: Moisture Absorption in \#5 Sand Coated BFRP Bars

- It was observed from the results that the maximum moisture absorption in \#4 and \#5 sand coated BFRP bar was $0.24 \%$ over a duration of 360 hours. The main absorption occurred on the first three days, then partially increased among the 360 hours.

\subsection{Summary}

\section{Tension test}

- Grip lengths and Adhesive: Different lengths of steel grip with Pliogrip adhesive were used depending on the diameter of basalt FRP bar. A grip length of 10 inch for \#4 bar and 11 inch for \#5 bars on each end was sufficient to successfully transfer the load.

- Bar Diameters: Different diameters of basalt FRP bars were tested in tension to determine their tensile strength. Bars with larger diameter \#4 (dia=0.500") and \#5 (dia= 0.625 ") had lower tensile stress, $118.57 \mathrm{ksi}$ and $106.69 \mathrm{ksi}$ respectively. That is because of the shear lag effect. 


\section{Compression Test}

- Stress: The average compressive stress of the BFRP bars was 30-40\% less than the average tensile stress. \#4 (dia=0.500") and \#5 (dia=0.625") had compressive strength of $62.24 \mathrm{ksi}$ and $69.50 \mathrm{ksi}$ respectively.

\section{Shear Test}

- Single shear stress for \#4 and \#5 BFRP bars were $26.12 \mathrm{ksi}$ and $23.95 \mathrm{ksi}$, respectively. While, double shear stress for \#4 and \#5 BFRP bars were $29.57 \mathrm{ksi}$ and $27.95 \mathrm{ksi}$, respectively. Single shear stress specimens are 10-12\% less than double shear stress specimens due to the effect of bending in single shear test.

\section{Inter-Laminar Shear Test}

- Failure Mode: All BFRP bar specimens were bent/curved through the center. Interlaminar shear stress values for \#4 BFRP bars were $7.40 \mathrm{ksi}$, while \#5 BFRP bars carried $7.25 \mathrm{ksi}$.

\section{Bond Test}

- Preliminary evaluations indicate that the pull-out bond strength of sand coated BFRP bars is similar to those of other sand-coated FRP bars. Previous studies have shown that the sand coated FRP bars have bond-stress in the range of 1700-2300 psi as compared to about 1700 psi for steel bars. These BFRP bars are sand coated and a comprehensive short- and long-term bond strength study will be carried out in the future. 


\section{Burn-off Test}

- The fiber volume fraction of basalt FRP bar was $71.68 \%$ for $\# 4$ bars and $67.96 \%$ for \#5 bars.

\section{Differential Scanning Calorimeter (DSC)}

- Glass transition temperature $\left(T_{g}\right)$ of BFRP is $109^{\circ} \mathrm{C}$. It is noted that the bars should be used at a temperature of $25^{\circ} \mathrm{F}$ below the glass transition temperature $\left(T_{g}\right)$ during their service life.

\section{Moisture Absorption}

- The maximum moisture absorption of \#4 and \#5 sand coated BFRP bars was about $0.24 \%$ over a duration of 360 hours of water immersion. 


\section{Concrete Beams with Basalt FRP}

\subsection{Introduction}

Concrete beams reinforced with FRP were tested under 3- and 4- point bending loads to evaluate their flexural behavior. Tests are described briefly along with the equipment, experimental setup, test procedures, and results. Following three types of beams were investigated in this research:

- Concrete beams bonded with basalt FRP fabrics.

- Concrete beams reinforced with basalt FRP bars.

- Concrete beams reinforced with basalt FRP bars and fabrics.

\subsection{Materials}

\subsubsection{Concrete}

Ready-mixed concrete was used in this study with a compressive strength of 4500 psi. Concrete was poured in the formwork with necessary BFRP and steel reinforcements. The formwork was removed after 48 hours and the concrete beams were cured by wet burlap. Beams were cast in two different batches to prepare a total of 12 beams ( 6 beams with steel reinforcement and 6 beams with BFRP reinforcement in tension).

\subsubsection{Steel Bars}

Steel bars were used as tension, compression and shear reinforcement for concrete beams. Steel bars with \#3 (diameter $=3 / 8 ”)$, \#4 (diameter $=0.5 ”)$, \#5 (diameter $=5 / 8$ ") were used to obtain desired failure modes in different beams. 


\subsubsection{Basalt FRP Bars}

Sand coated basalt FRP bars of \#4 (diameter $=0.5 ")$ and \#5 (diameter $=5 / 8 ")$ sizes obtained from Raw Energy Material Corporation were used as internal tensile reinforcements for concrete beams.

\subsubsection{Basalt FRP Fabric}

Basalt fabrics were obtained from Raw Energy Material Corporation were used as external reinforcement for concrete beams (Figure 5.3).

\subsubsection{Resin/Hardener}

Two-part epoxy resin/hardener (obtained from West System Inc) was used to saturate the BFRP fabrics. Epoxy resin (105) is a clear, pale yellow, low-viscosity liquid, designed to wet out reinforcing fabric with a proper ratio of hardener (205). This is designed to wet out reinforcing fabrics and bond them to concrete surface. Pot life of the mixed resin and hardener combination is $20-25$ min with a working time of $90-110$ min. Epoxy system $(105 / 205)$ has advantages such as high strength and moisture resistant bonding and barrier coating properties. The proper volume ratio of epoxy resin to hardener is $5: 1$. 


\subsection{Concrete Beams with Bonded Basalt FRP Fabric}

\subsubsection{Specimen Description}

The concrete beam specimens measured 6"x 15"x120". They were reinforced with 3 \#4 steel bars on compression side, and $2 \# 3$ steel bars on tension side. Beams were tested under fourpoint bending for different loading and unloading cycles prior to failure.

\subsubsection{Procedure of Bending Concrete Beams with BFRP Fabrics}

Reinforced concrete beams were cast in formwork. Tension and compression reinforcement were provided in all beams. Formwork surfaces were cleaned and oiled after assembling (Figure 4.1). Before pouring concrete, beam dimension and reinforcement position were checked and adjusted. While pouring concrete, vibrator machine was used to release trapped air and consolidate the concrete. Concrete beams were removed from formwork after 2 days from casting and were cured for 28 days. 


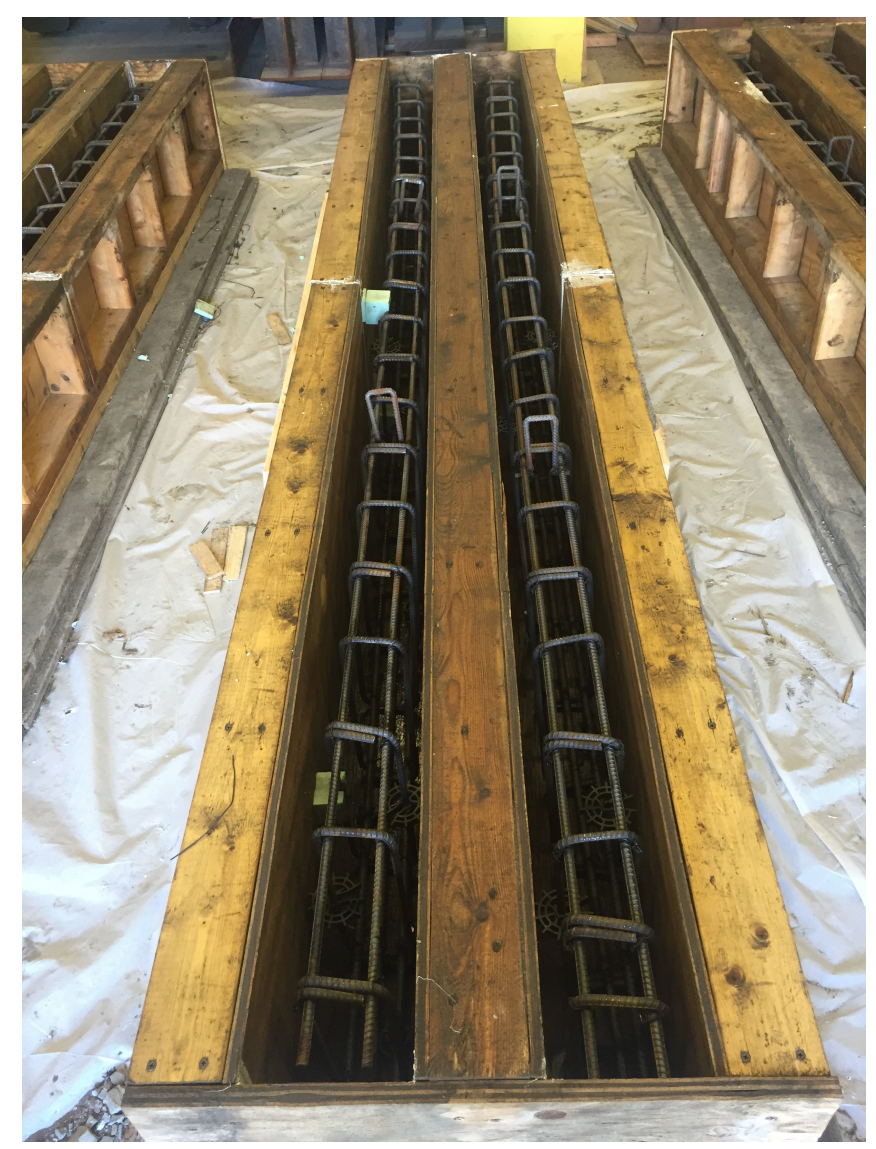

Figure 4.1: Formwork with Reinforcements for Concrete Beams

After curing, tension side of the beams were cleaned and sanded for bonding BFRP fabric. Beams were prepared in the following two configurations:

- Beams were loaded up to a cracking load, point and the basalt FRP fabric was bonded on the tension side.

- Beams were damaged by chiseling in the middle -third zone (L/3) of the beam and repaired by using motar. Following the repair, the beams were loaded up to a cracking load and then bonded with basalt FRP fabric on the tension side.

Basalt FRP fabrics were bonded to the beam by applying resin and hardener mixed in ratio of a 5:1. Epoxy mix was applied on the fabric and the beam surface with the help of a thin 
plastic plate. Any possible air bubbles were removed. Same procedure was repeated for applying a new layer of basalt FRP fabric. Beams bonded with basalt fabrics were cured for at least 48 hours prior to testing.

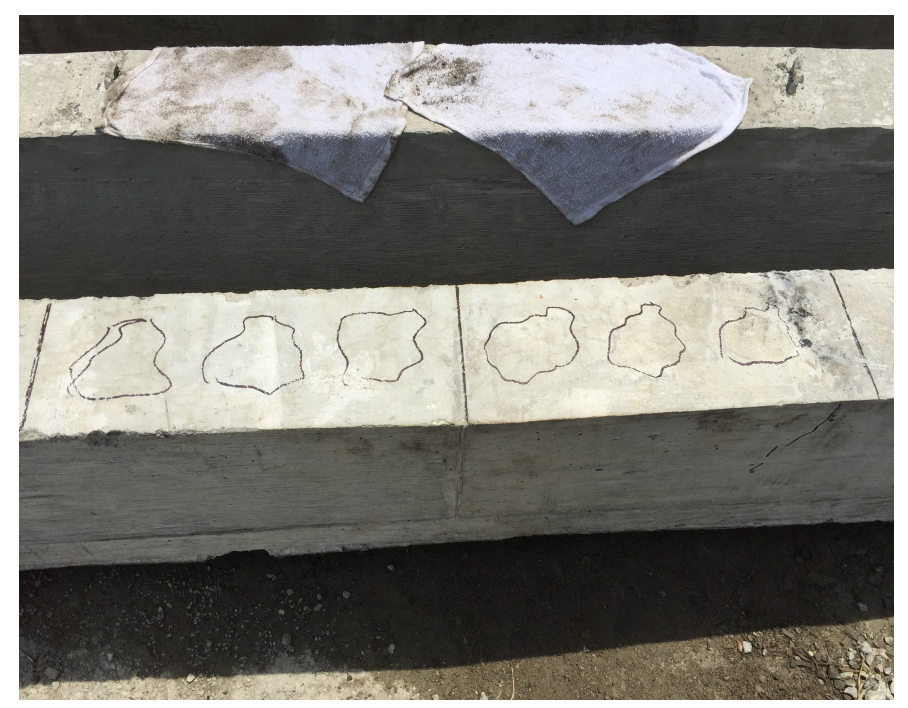

Figure 4.2: Damaged Area on the Beam Bottom (Tension Side) at L/3

\subsubsection{Experiment and Test Set-Up}

Uniaxial strain gages were bonded to the top and bottom surfaces of the beam specimens. Concrete strain gage was attached at the center of the beam's compression side surface (top) and regular strain gages were bonded on the beam's tension side (bottom) over the BFRP fabric. Beams were placed on simple supports with an overhang of 6 inches on each side. Hydraulic jack was positioned at mid span. Load and deflection of test beams were measured by calibrated load cell and LVDT located at mid span (L/2). Load cell, LVDT and strain gages were connected to data acquisition for recording data. Four-point bending test, loads were manually applied in a 
gradual manner. Beams were loaded and unloaded for multiple cycles with a load increment in each successive cycle until failure.

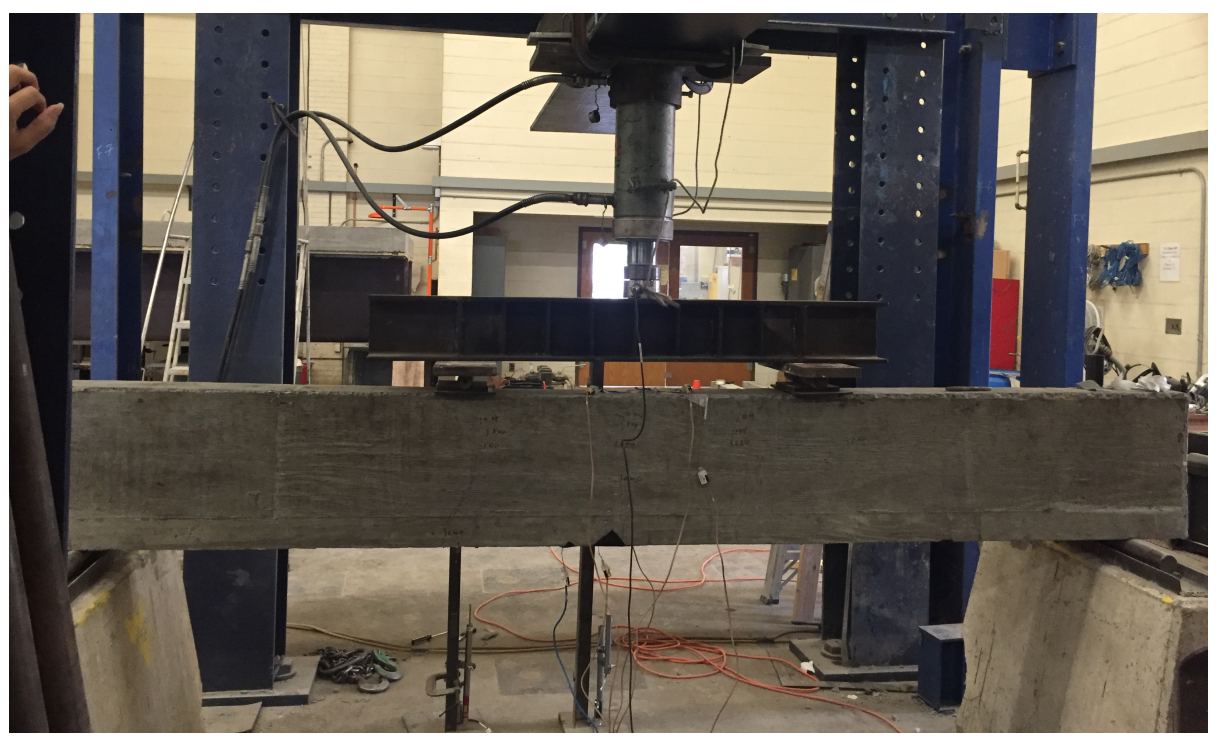

Figure 4.3: Four-Point Bending Test

\subsubsection{Test Results}

Results of the beams (6"x15"x120") bonded with 2 and 3 longitudinal BFRP layers at the bottom are presented in terms of the maximum failure load, maximum moment, and deflection in Table 4.1. The experimental load (moment) values of beams under four-point bending are compared with the theoretical values based on the bending theory of reinforced concrete beams as shown in Table 4.1 
Table 4.1: Four-point Bending Test Results of 6"x"15"x120" Beams Bonded with BFRP Fabric

\begin{tabular}{|c|c|c|c|c|c|c|}
\hline \multirow{3}{*}{$\begin{array}{l}\text { No. of } \\
\text { layers }\end{array}$} & \multirow{3}{*}{ Beam Type } & $\begin{array}{c}\text { Max. Load } \\
\text { (Avg) }\end{array}$ & Max. Load & $\begin{array}{l}\text { Max. Moment } \\
\text { (Avg) }\end{array}$ & $\begin{array}{c}\text { Max. } \\
\text { Moment }\end{array}$ & \multirow{2}{*}{$\begin{array}{l}\text { Max. Load } \\
\text { Ratio (Avg) }\end{array}$} \\
\hline & & (Exptl.) & (Theor.) & (Exptl.) & (Theor.) & \\
\hline & & (kip) & (kip) & (kip-ft) & (kip-ft) & Exptl./Theor. \\
\hline 0 & Base & 12.73 & 9.58 & 19.10 & 14.30 & 1.327 \\
\hline 2 & $\begin{array}{c}\text { Damaged and } \\
\text { Cracked }\end{array}$ & \multirow[t]{2}{*}{20.14} & \multirow[t]{2}{*}{21.15} & \multirow[t]{2}{*}{30.20} & \multirow[t]{2}{*}{31.73} & \multirow[t]{2}{*}{1.008} \\
\hline 2 & Cracked Only & & & & & \\
\hline 3 & Cracked Only & 21.73 & 26.60 & 32.60 & 39.90 & 0.817 \\
\hline
\end{tabular}

Steel reinforcement failure loads are typically $30 \%$ or higher than the yield value. Once yield stress and strain are reached in a steel bar, the beam continues to take an additional load with rapidly increasing plastic deformations. Since the beams are lightly reinforced and compression zone has higher reserve force, higher experimental to theoretical strength value is noted for base beam.

From the results of damaged and cracked beams bonded with BFRP wrap, beams with 2 layers of BFRP wrap had 58\% higher load (moment) capacity than the base beam (20.14 kips vs. 12.72 kips). Beam with 3 layers of BFRP wrap had $71 \%$ higher load (moment) capacity than the base beam (21.73 kips vs. 12.73 kips). Also, as shown from the results, as the number of wrap increase, the strain on the bonded BFRP fabric increases too. For a given load, the deflection of beam wrapped with 2 and 3 layers of BFRP fabric are $25 \%$ and $43 \%$ lower than the deflection of base beam and within $40 \%$ of the failure load of the base beam. Lower deflections indicate the ability of BFRP fabrics to add to the overall stiffness of the beam. 


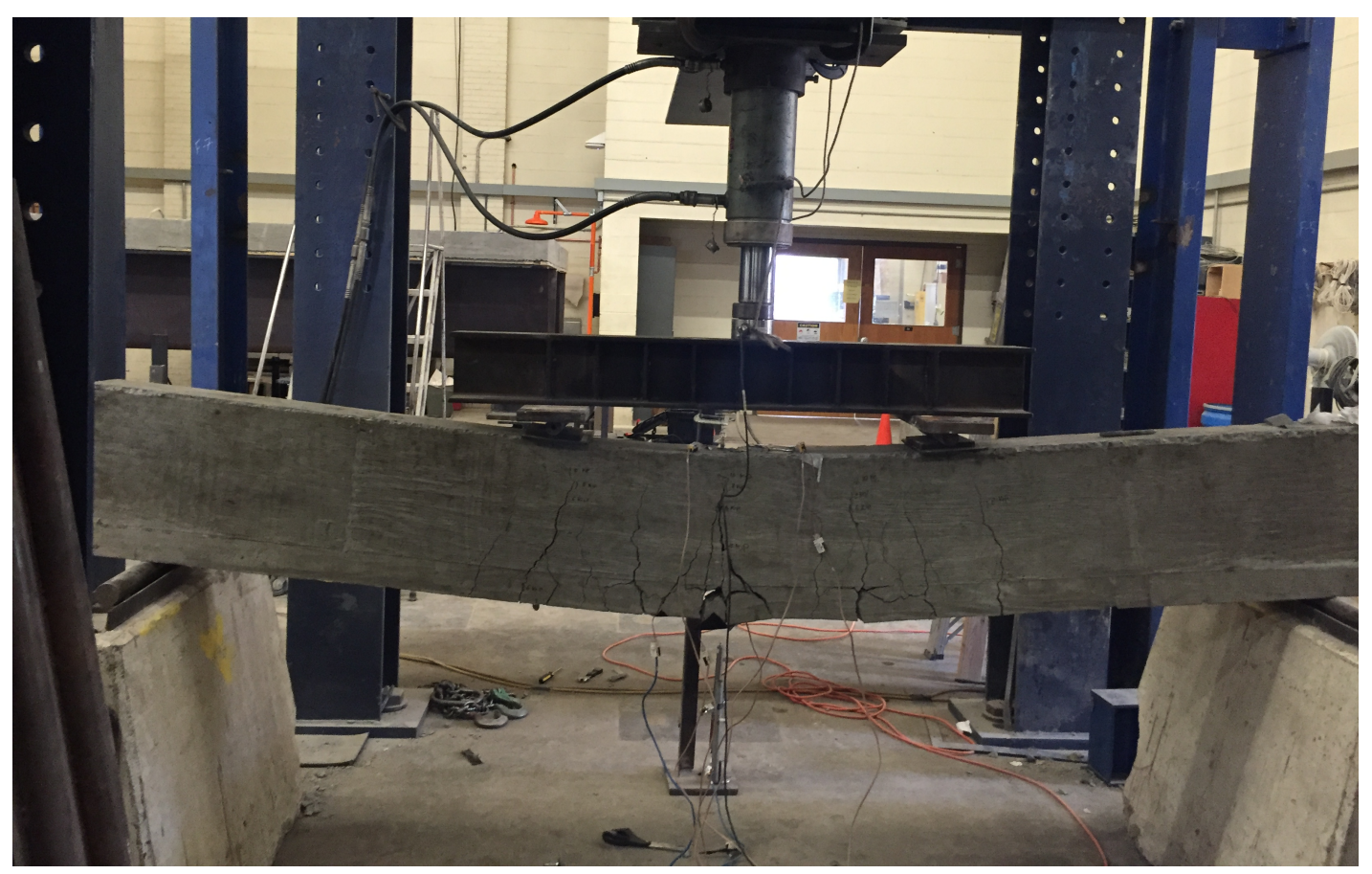

Figure 4.4: Failure Mode of Concrete Base Beam

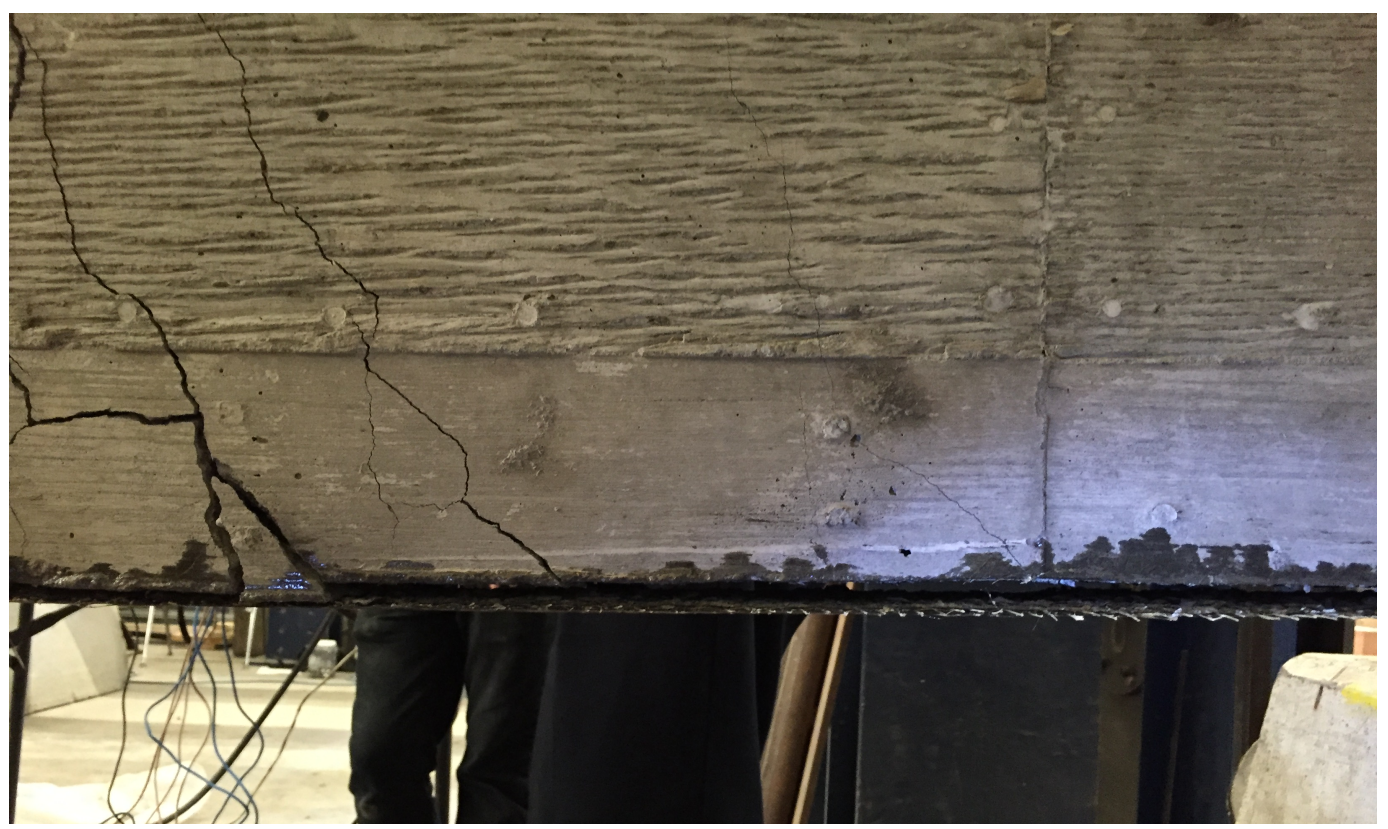

Figure 4.5: Failure Mode of Concrete Beam Bonded with BFRP Fabrics 
The beams with BFRP fabrics showed 15518 micro-strains at failure and fabric de-bonding was noted. The de-bonding indicates that a specialized primer may help in further increasing the bond strength between concrete and BFRP fabric.

\subsubsection{Theoretical Evaluation}

Theoretical calculations of the maximum load and maximum moment capacity for the base beam and the beams with 2 and 3 layers of BFRP fabrics are provided in the following sections

\subsubsection{Ultimate Strength Design}

The behavior of concrete beam is considered to be non-linear in the ultimate strength design. The equivalent rectangular stress block has a mean stress of $0.85 f_{c}^{\prime}$ and depth of 'a'.

\section{Force equilibrium:}

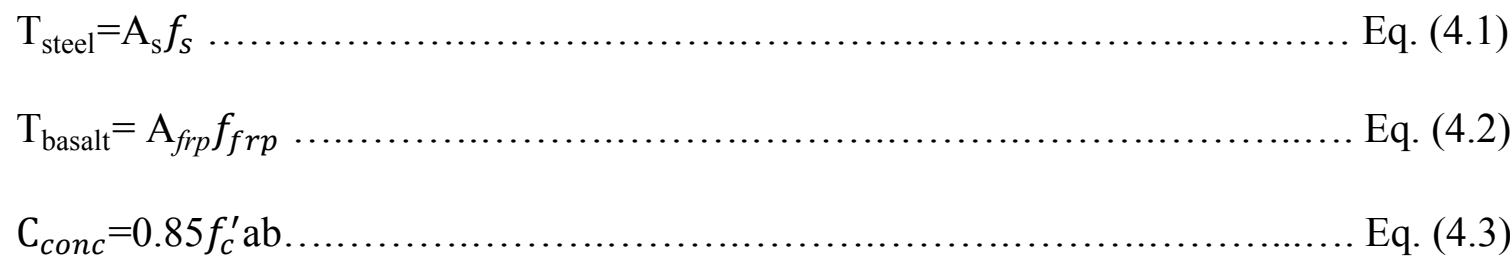

Tensile force $(T)=$ Compressive force $(C)$

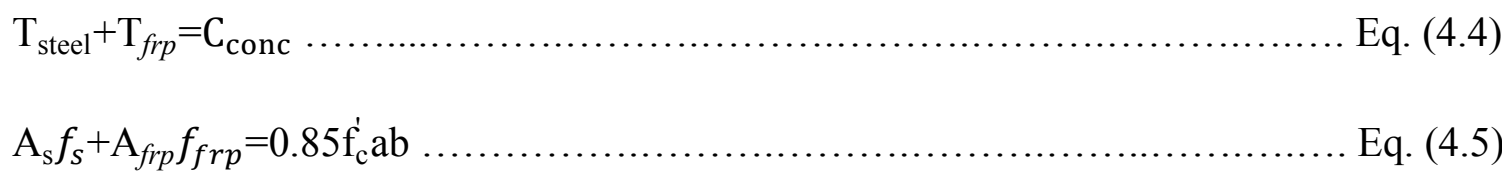




\section{Moment equilibrium:}

\section{Over all moment equilibrium:}

$$
\mathrm{M}_{\mathrm{n}}=\mathrm{A}_{\mathrm{s}} f_{s}\left(\mathrm{~d}-\frac{\mathrm{a}}{2}\right)+\mathrm{A}_{\mathrm{frp}} f_{f r p}\left(\mathrm{~h}-\frac{\mathrm{a}}{2}\right)
$$

\section{Moment equilibrium for tension failure:}

$$
\begin{aligned}
& M_{n}=T\left[d-\frac{a}{2}\right] \ldots \\
& M_{n}=T_{t o t}[0.85 d]
\end{aligned}
$$

Where,

$f_{c}^{\prime}=$ Concrete ultimate stress

$f_{s}=$ Steel tensile stress

$f_{f r p}=$ Basalt tensile stress

$\mathrm{A}_{\mathrm{s}}=$ Area of steel

$\mathrm{A}_{f r p}=$ Area of basalt FRP

$T_{\text {tot }}=$ Total force

$T_{\text {steel }}=$ Total force taken by steel

$T_{f r p}=$ Total force taken by FRP

$\mathrm{C}_{\text {conc }}=$ Total force taken by concrete

$d=$ Effective depth of the beam

$h=$ Total depth of the beam 
Example 1: Base concrete beam with steel bars only

$b=6$ inch

$\mathrm{h}=15$ inch

$\mathrm{d}=13.31 \mathrm{inch}$

$\mathrm{d}^{\prime}=1.6875 " \sim 1.69$

Reinforcement:

Compression $=3 \# 4$ steel bars

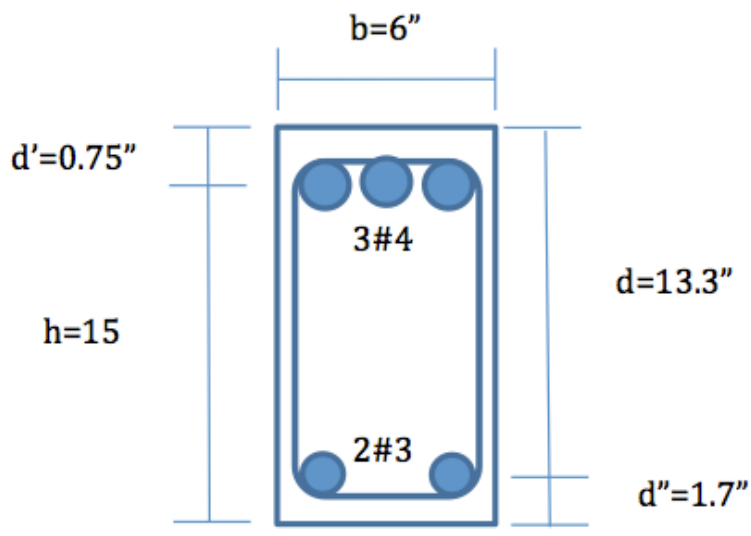

Tension $=2 \# 3$ steel bars

\section{Given:}

$$
\begin{aligned}
& f_{c}^{\prime}=4.5 \mathrm{ksi} \\
& f_{y}=60 \mathrm{ksi} \\
& A_{s} \# 3=0.11 \mathrm{in}^{2} \\
& A_{s} \# 4=0.20 \mathrm{in}^{2} \\
& \beta_{1}=0.825
\end{aligned}
$$

Solution: Assumed tension failure for beam with compression and tension bar only (no

\section{FRP fabric)}

From equilibrium: Total compression force $=$ Total tension force

$$
\begin{gathered}
\mathrm{C}_{\text {concrete }}=\mathrm{T}_{\text {steel }}+\mathrm{T}_{f r p} \\
85 f_{c}^{\prime} \mathrm{ab}+\mathrm{A}_{\mathrm{s}} f_{s}=f_{s} \\
a=\beta c \\
\mathrm{C}=0.85 \times 4500 \times 0.825 \times c \times 6+(0.20 \times 2) \times 60000
\end{gathered}
$$




$$
\begin{gathered}
\mathrm{T}=(0.11 \times 2) \times 60000 \\
c=0.570 \text { inch }, a=0.4706 \text { inch } \\
108,800 \mathrm{lb}=13,200 \mathrm{lb} \rightarrow \text { Tension Failure }
\end{gathered}
$$

Moment at which at first crack occur:

$$
\begin{gathered}
M_{c r}=f_{c r} \times \frac{I}{y} \\
=7.5 \sqrt{4500} \times \frac{b^{2}}{6} \\
=7.5 \sqrt{4500} \times 6 * \frac{15^{2}}{6} \\
=113,200.94 \mathrm{lb} . \mathrm{in} \\
=9.43 \mathrm{kip} . \mathrm{ft}
\end{gathered}
$$

Load at which at first crack occur: $\operatorname{span}=108$ inch $=9 \mathrm{ft}$

$$
\begin{aligned}
P_{c r} & =9.433 \times \frac{6}{9} \\
& =6.29 \mathrm{kip}
\end{aligned}
$$

Resisting moment of non-wrapped beam:

$$
\begin{gathered}
\mathrm{M}_{\mathrm{n}}=\mathrm{A}_{\mathrm{s}} f_{s}\left(\mathrm{~d}-\frac{\mathrm{a}}{2}\right) \\
=[(0.11 \times 2)] \times 60000 \times \times\left(13.31-\frac{0.4706}{2}\right) \\
\mathrm{M}_{\mathrm{n}}=172.59 \text { kip.in } \\
\mathrm{M}_{\mathrm{n}}=14.38 \text { kip.ft }
\end{gathered}
$$


From four point bending test: $\operatorname{span}=108 \mathrm{inch}=9 \mathrm{ft}$

$$
\begin{aligned}
\mathrm{P}_{\mathrm{n}} & =6 \mathrm{M}_{\mathrm{n}} / \mathrm{span} \\
& =6 \times \frac{14.38}{9} \\
& =9.59 \mathrm{kip}
\end{aligned}
$$

Hence, Maximum load and resisting moment from theory are 9.59 kip and 14.38 kip.ft, respectively. Experimental values are within $32.7 \%$ of the theoretical values. (Table 4.1)

Example 2: Concrete beam bonded with 2 layers of FRP fabric

$$
\begin{aligned}
& b=6 \text { inch } \\
& h=15 \text { inch } \\
& d=13.31 \text { inch } \\
& d^{\prime}=1.6875^{\prime \prime} \sim 1.69
\end{aligned}
$$

\section{Reinforcement:}

Compression= $3 \# 4$ steel bars

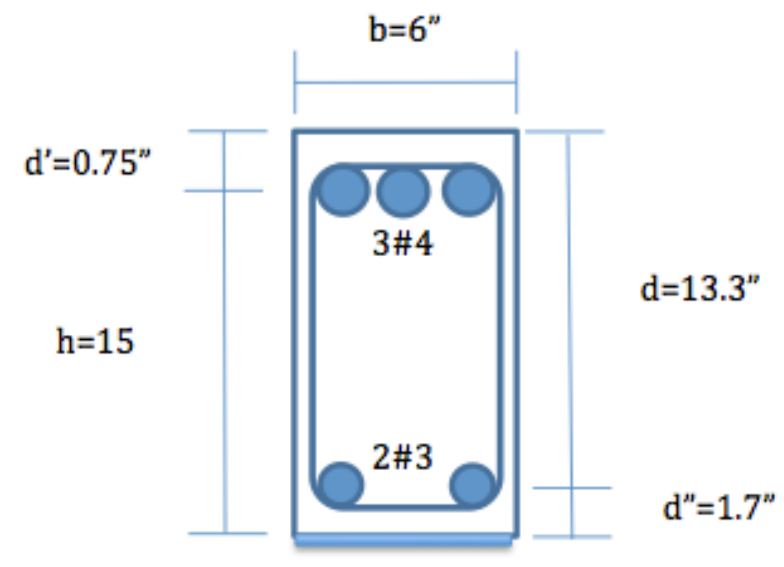

Tension $=2 \# 3$ steel bars

\section{Given:}

$$
\begin{aligned}
& f_{c}^{\prime}=4.5 \mathrm{ksi} \\
& f_{y}=60 \mathrm{ksi} \\
& A_{s} \# 3=0.11 \mathrm{in}^{2}
\end{aligned}
$$




$$
\begin{aligned}
& A_{s} \# 4=0.20 \mathrm{in}^{2} \\
& \beta_{1}=0.825
\end{aligned}
$$

BFRP load for 1 layer/unit width $=1162 / 0.75=1550 \mathrm{lb}($ width $=0.75 \mathrm{inch}$, Table 5.5)

\section{Solution: Assumed tension failure for beam with compression and tension bar only (no}

\section{FRP fabric)}

From equilibrium: Total compression force $=$ Total tension force

$$
\begin{gathered}
\mathrm{C}_{\text {concrete }}=\mathrm{T}_{\text {steel }}+\mathrm{T}_{\text {frp }} \\
0.85 f_{c}^{\prime} \mathrm{ab}+\mathrm{A}_{\mathrm{s}} f_{s}=\mathrm{A}_{\mathrm{s}} f_{s}+\mathrm{A}_{\text {frp }} f_{f r p} \\
A_{f r p}=\mathrm{n} t_{f} \mathrm{~b}
\end{gathered}
$$

Where, $\mathrm{n}=$ number of layer

$$
\begin{aligned}
& t_{f}=\text { Fabric thickness } \\
& \text { b=beam with } \\
& \qquad \mathrm{C}=0.85 \times 4500 \times 0.825 \times \mathrm{c} \times 6+(0.20 \times 2) \times 60000 \\
& \mathrm{~T}=\mathrm{T}_{1}+\mathrm{T}_{2}=(0.11 \times 2) \times 60000+(1 \times 6 \times 0.02) *\left(\frac{1150}{0.02}\right) \\
& \qquad T_{1}=A_{s t} f_{y} \\
& \qquad T_{2}=n b A_{f r p} f_{f r p} \\
& c=0.158 \text { inch, } \quad \mathrm{a}=0.131 \text { inch } \\
& 27,006 \mathrm{lb}=27,000 \mathrm{lb} \quad \rightarrow \text { Tension Failure }
\end{aligned}
$$

\section{Resisting moment for 2 layers of BFRP wrapped beam:}

$$
\mathrm{M}_{\mathrm{n}}=\mathrm{T}_{1}\left[\mathrm{~d}-\frac{\mathrm{a}}{2}\right]+\mathrm{T}_{2}\left[\mathrm{~h}-\frac{\mathrm{a}}{2}\right]
$$




$$
\begin{gathered}
M_{n}=13,200\left[13.3-\frac{.131}{2}\right]+13,800\left[15-\frac{0.131}{2}\right] \\
=174,695+206,096 \\
M_{n}=380.81 \text { kip.in } \\
M_{n}=31.73 \text { kip.ft }
\end{gathered}
$$

From four point bending test: $\operatorname{span}=108 \mathrm{inch}=9 \mathrm{ft}$

$$
\begin{aligned}
P_{n} & =6 M_{n} / \text { span } \\
& =6 \times \frac{31.73}{9} \\
& =21.15 \mathrm{kip}
\end{aligned}
$$

Hence, Maximum load and resisting moment from theory are 21,15 kip and $31.73 \mathrm{kip.ft}$, respectively. Experimental values are within $0.8 \%$ of the theoretical values. (Table 4.1)

Example 3: Concrete beam bonded with 3 layers of FRP fabric

$$
\begin{aligned}
& b=6 \text { inch } \\
& h=15 \text { inch } \\
& d=13.31 \text { inch } \\
& d^{\prime}=1.6875^{\prime \prime} \sim 1.69
\end{aligned}
$$

\section{Reinforcement:}

Compression $=3 \# 4$ steel bars

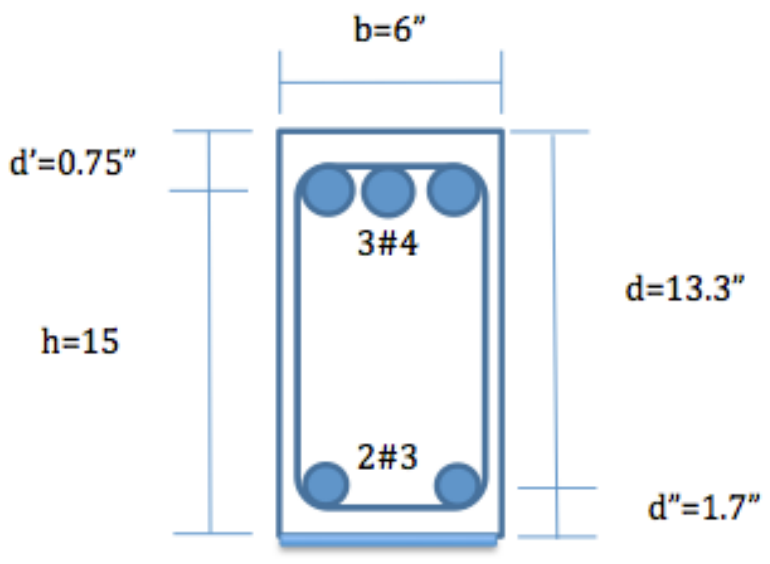

Tension $=2 \# 3$ steel bars 


\section{Given:}

$$
\begin{aligned}
& f_{c}^{\prime}=4.5 \mathrm{ksi} \\
& f_{y}=60 \mathrm{ksi} \\
& A_{s} \# 3=0.11 \mathrm{in}^{2} \\
& A_{s} \# 4=0.20 \mathrm{in}^{2} \\
& \beta_{1}=0.825
\end{aligned}
$$

BFRP load for 1 layer/unit width $=1162 / 0.75=15501 \mathrm{~b}($ width $=0.75$ inch, Table 5.5)

Solution: Assumed tension failure for beam with compression and tension bar only (no

\section{FRP fabric)}

From equilibrium: Total compression force $=$ Total tension force

$$
\begin{gathered}
\mathrm{C}_{\text {concrete }}=\mathrm{T}_{\text {steel }}+\mathrm{T}_{\text {frp }} \\
0.85 f_{c}^{\prime} \mathrm{ab}+\mathrm{A}_{\mathrm{s}} f_{s}=\mathrm{A}_{\mathrm{s}} f_{s}+\mathrm{A}_{\text {frp }} f_{f r p} \\
A_{f r p}=\mathrm{n} t_{f} \mathrm{~b}
\end{gathered}
$$

Where, $\mathrm{n}=$ number of layer

$t_{f}=$ Fabric thickness

$b=$ beam with

$$
\begin{gathered}
\mathrm{C}=0.85 \times 4500 \times 0.825 \times \mathrm{c} \times 6+(0.20 \times 2) \times 60000 \\
\mathrm{~T}=\mathrm{T}_{1}+\mathrm{T}_{2}=(0.11 \times 2) \times 60000+(21 \times 6 \times 0.02) *\left(\frac{1150}{0.02}\right) \\
T_{1}=A_{s t} f_{y} \\
T_{2}=n b A_{f r p} f_{f r p} \\
c=0.523 \text { inch, } \quad \mathrm{a}=0.431 \text { inch }
\end{gathered}
$$




$$
\text { 33,902 lb }=33,900 \mathrm{lb} \quad \rightarrow \text { Tension Failure }
$$

Resisting moment for 3 layers of BFRP wrapped beam:

$$
\begin{gathered}
\mathrm{M}_{\mathrm{n}}=\mathrm{T}_{1}\left[\mathrm{~d}-\frac{\mathrm{a}}{2}\right]+\mathrm{T}_{2}\left[\mathrm{~h}-\frac{\mathrm{a}}{2}\right] \\
\mathrm{M}_{\mathrm{n}}=13,200\left[13.3-\frac{.431}{2}\right]+27,700\left[15-\frac{0.431}{2}\right] \\
=172,715+306,039 \\
\mathrm{M}_{\mathrm{n}}=478.75 \text { kip.in } \\
\mathrm{M}_{\mathrm{n}}=39.90 \text { kip.ft }
\end{gathered}
$$

From four point bending test: $\operatorname{span}=108$ inch $=9 \mathrm{ft}$

$$
\begin{aligned}
P_{n} & =6 M_{n} / s p a n \\
& =6 \times \frac{39.90}{9} \\
& =26.60 \mathrm{kip}
\end{aligned}
$$

Hence, Maximum load and resisting moment from theory are 26.60 kip and 39.90 kip.ft, respectively. Experimental values are within $18 \%$ of the theoretical values. (Table 4.1)

\subsection{Concrete Beams with External and Internal BFRP Reinforcement}

\subsubsection{Specimen Description}

The concrete beam specimens measured 6"x15"x72" and were reinforced with $1 \# 4$ and 2\#5 of steel bars on compression side. BFRP bars were used on tension side consisted of \#4 and \#5 sizes. Beams with both bar sizes were bonded with fabrics as follows: 
Table 4.2: Number of BFRP Layers Bonded with Reinforced BFRP Bar

\begin{tabular}{|c|c|c|c|}
\hline \multirow{2}{*}{ Beam } & \multirow{2}{*}{$\begin{array}{c}\text { Compression } \\
\text { Steel }\end{array}$} & \multicolumn{2}{|c|}{ BFRP Tension } \\
\hline & & BFRP Bar & BFRP Fabric \\
\hline 1 & \multirow{4}{*}{$1 \# 4,2 \# 5$} & \multirow{2}{*}{$2 \# 4$} & 1 Layer \\
\hline 2 & & & 2 Layers \\
\hline 3 & & \multirow{2}{*}{$2 \# 5$} & 1 Layer \\
\hline 4 & & & 2 Layers \\
\hline
\end{tabular}

Beams were tested under three-point bending. Each beam was loaded in several cycles of loading and unloading until failure.

\subsubsection{Concrete Beams with External and Internal BFRP Reinforcement}

Reinforced concrete beams were cast in formwork. Tension and compression reinforcements were provided in all beams. Formwork surfaces were cleaned and oiled after assembling. Before pouring concrete, beam dimension and reinforcement position were checked and adjusted. While pouring concrete, a vibrator was used to release trapped air and consolidate concrete. Concrete beams were removed from formwork after 2 days and were cured for 28 days. The beams were loaded until the first crack was developed. After achieving first crack BFRP fabrics were bonded to the tension side (bottom) of the beam and were finally tested under bending.

\subsubsection{Experiment and Test Set-Up}

Uniaxial strain gages were bonded to the top and bottom surfaces of the beam specimens Concrete strain gage was attached at the center of the beam's compression side surface (top) and regular strain gages were bonded on the beam's tension side (bottom) over the BFRP fabric. Beams were placed on simple supports with an overhang of 6 inches on each side. Hydraulic jack was positioned at mid span. Load and deflection of test beams were measured by calibrated 
load cell and LVDT located at mid span (L/2). Load cell, LVDT and strain gages were connected to data acquisition for recording data. Four-point bending test, loads were manually applied in a gradual manner. Beams were loaded and unloaded for multiple cycles with a load increment in each successive cycle until failure.

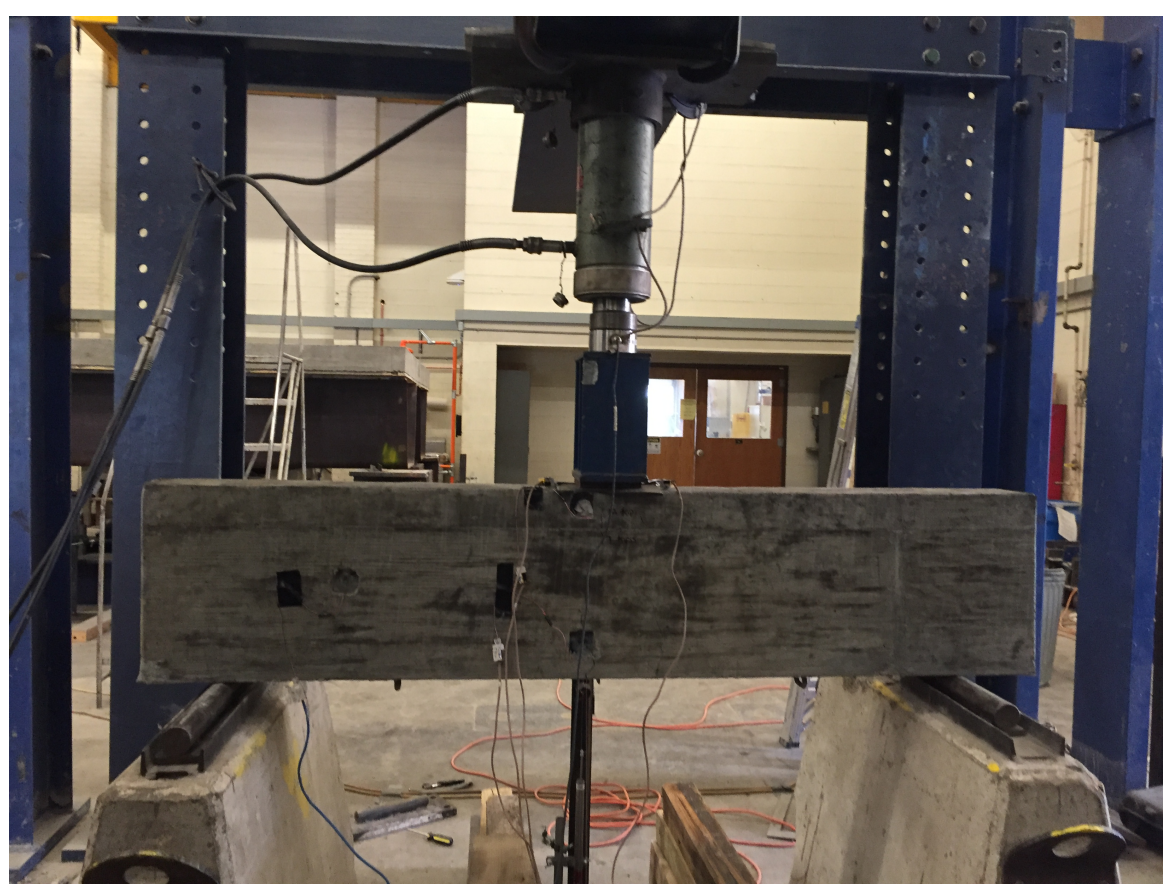

Figure 4.6: Three-Point Bending Test

\subsubsection{Test Results}

Results of beams (6"x15"x72") reinforced with BFRP bars and bonded with BFRP fabrics at the bottom of the beam (tension side) are presented in terms of the maximum failure load, maximum moment, and deflection in Table 4.3. The experimental load (moment) values of beams under three-point bending are compared with the theoretical values based on the bending theory of reinforced concrete beams as shown in Table 4.3 
As shown from Table 4.3 beams with \#4 BFRP internal reinforcement along with 1 and 2 layers of BFRP fabrics carries 20\% (experimental and theoretical) and 40\% (theoretical) higher load than the base beam, respectively. Similarly, beams with \#5 BFRP internal reinforcement along with 1 layer and 2 layers of BFRP fabric carries 26\% and 47\% higher load than the base beam, respectively.

Experimental values of load (moment) for beams with \#4 bars and no wraps, single wrap and two layers of wrap were within $7 \% .5 \%$, and $17 \%$ of the theoretical values, respectively. Similarly, experimental values of load (moment) for beams with \#5 bars and no wraps, single wrap and 2 layers of wrap were within $8 \%, 20 \%$ and $24 \%$ of the theoretical value, respectively.

Table 4.3: Maximum Load (moment) Capacities of 6" $x " 15$ "x72" Concrete Beam with BFRP Reinforcement

\begin{tabular}{|c|c|c|c|c|c|c|c|}
\hline \multirow{3}{*}{$\begin{array}{l}\text { Reinforcement } \\
\text { BFRP Bar size }\end{array}$} & \multirow{3}{*}{$\begin{array}{l}\text { No. of } \\
\text { layers }\end{array}$} & Max. Load & $\begin{array}{l}\text { Max. } \\
\text { Load }\end{array}$ & $\begin{array}{c}\text { Max. } \\
\text { Moment }\end{array}$ & $\begin{array}{c}\text { Max. } \\
\text { Moment }\end{array}$ & \multirow{2}{*}{$\begin{array}{l}\text { Strength } \\
\text { Increase }\end{array}$} & \\
\hline & & (exptl.) & (theor.) & (exptl.) & (theor.) & & Ratio \\
\hline & & (kips) & (kips) & (kip-ft) & (kip-ft) & (\%) & Exptl./Theor. \\
\hline \multirow{3}{*}{$\# 4$} & 0 & 33.60 & 31.54 & 42.00 & 39.43 & - & 1.065 \\
\hline & 1 & 40.26 & 36.72 & 50.33 & 45.90 & 19.82 & 1.096 \\
\hline & 2 & 37.80 & 41.9 & 47.25 & 52.37 & 12.50 & 0.902 \\
\hline \multirow{3}{*}{ \#5 } & 0 & 52.80 & 48.81 & 66.00 & 61.01 & - & 1.082 \\
\hline & 1 & 66.77 & 54.06 & 83.46 & 67.58 & 26.46 & 1.235 \\
\hline & 2 & 77.83 & 62.7 & 97.29 & 78.38 & 47.41 & 1.241 \\
\hline
\end{tabular}




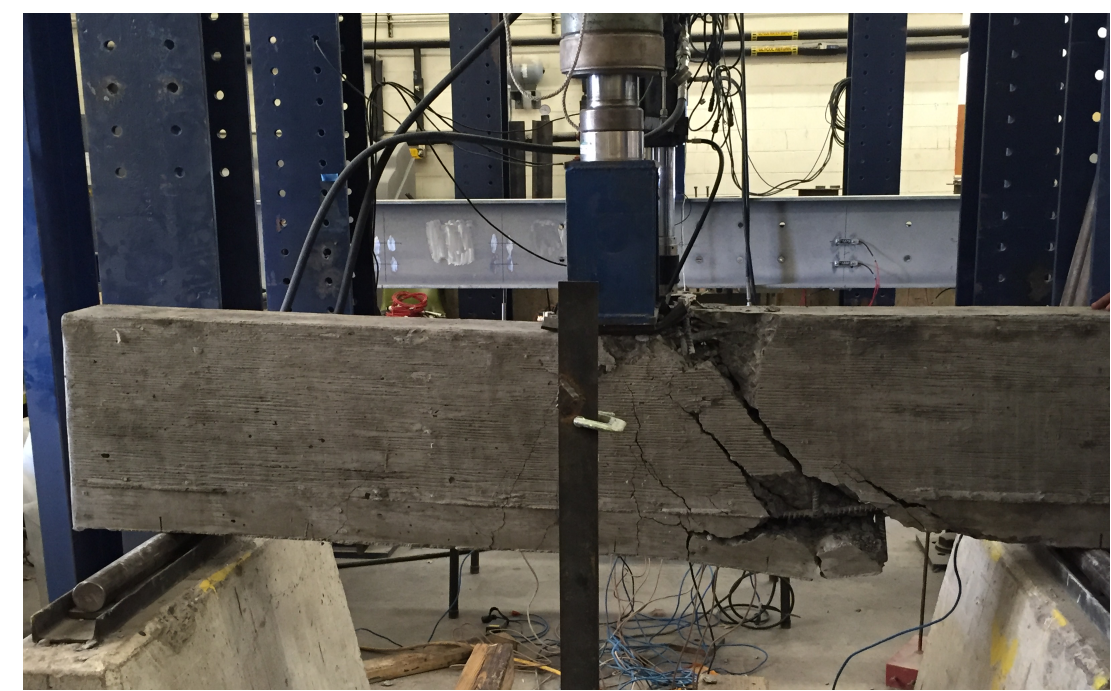

Figure 4.7: Failure Mode of Concrete with BFRP Bar Reinforcement (base)

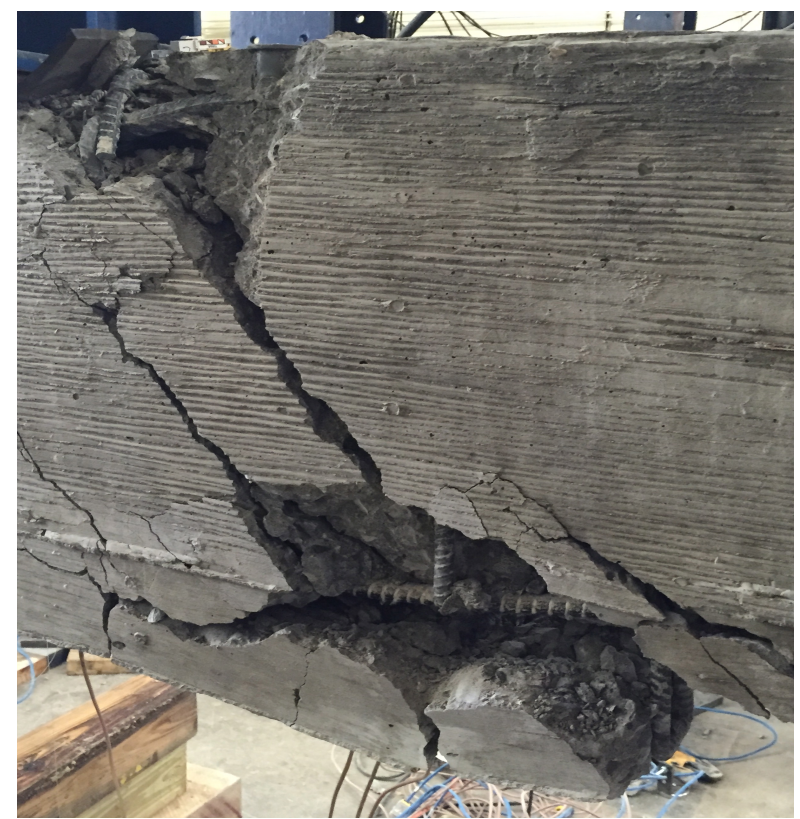

Figure 4.8: Failure Mode of Concrete with BFRP Bar Reinforcement (base) 


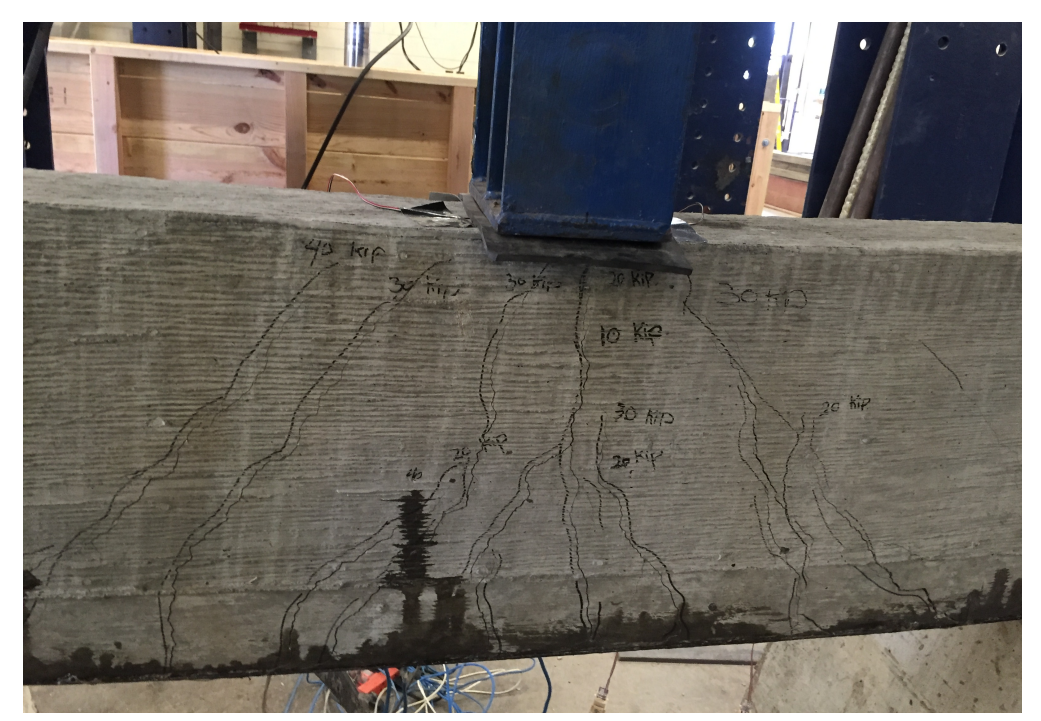

Figure 4.9: Cracked Concrete Beam with Internal and External BFRP Reinforcement

Beams with BFRP bars showed shear-compression failure (Figure 4.8). When additional BFRP fabrics were bonded, the failure modes were relatively ductile as shown in Figure 4.9.

\subsubsection{Crack Width}

Table 4.4 shows the crack width of concrete beams with internal and external basalt FRP. The crack widths of beams were in the range of $0.016 "-0.025$ ". It is also noted that at load of 30 kips, the deflections were reduced with increasing area of tensile reinforcements with increasing number of FRP fabric layers. At 30 kips, beams with \#4 bars and 1 and 2 layers of FRP fabrics showed crack- widths of $0.025 "$ and 0.013 ", respectively. Similarly, at $20 \mathrm{kips}$, beams with \#5 bars and 1 and 2 layers of FRP fabrics showed crack-widths of 0.011 " and 0.007 ", respectively. 
Table 4.4: Experimental Crack widths of Concrete Beams Reinforced with Internal and External Basalt BFRP

\begin{tabular}{|c|c|c|c|c|}
\hline \multicolumn{3}{|c|}{ Beam } & \multirow{2}{*}{$\begin{array}{l}\text { Load } \\
\text { (kip) }\end{array}$} & \multirow{2}{*}{$\begin{array}{c}\text { Crack } \\
\text { Width } \\
\text { (in) }\end{array}$} \\
\hline & BFRP Bar & BFRP Fabric & & \\
\hline \multirow{3}{*}{1} & \multirow{3}{*}{$\# 4$} & \multirow{3}{*}{1 layer } & 10 & 0.007 \\
\hline & & & 20 & 0.016 \\
\hline & & & 30 & 0.025 \\
\hline \multirow{2}{*}{2} & \multirow{2}{*}{$\# 4$} & \multirow{2}{*}{2 layers } & 15 & 0.007 \\
\hline & & & 30 & 0.013 \\
\hline \multirow{3}{*}{3} & \multirow{3}{*}{ \#5 } & \multirow{3}{*}{1 layer } & 16 & 0.003 \\
\hline & & & 30 & 0.011 \\
\hline & & & 50 & 0.025 \\
\hline \multirow{3}{*}{4} & \multirow{3}{*}{ \#5 } & \multirow{3}{*}{2 layers } & 15 & 0.003 \\
\hline & & & 30 & 0.007 \\
\hline & & & 45 & 0.016 \\
\hline
\end{tabular}

\subsubsection{Theoretical Evaluation}

In this section, theoretical calculations to find the maximum load and the maximum moment capacity for the base beam and the beams with BFRP reinforcement and BFRP layers have been performed.

\subsubsection{Maximum Load (Moment) Capacity}

\section{Example 4: Base concrete beam reinforced with \#4 BFRP bar}

\section{Dimension:}

$$
\begin{aligned}
& \mathrm{b}=6 \text { inch } \\
& \mathrm{h}=15 \text { inch } \\
& \mathrm{d}=13.25 \mathrm{inch} \\
& \mathrm{d}^{\prime}=1.0625^{\prime \prime} \cong 1.1 \mathrm{inch} \\
& \mathrm{d}^{\prime \prime}=1.75^{\prime}
\end{aligned}
$$

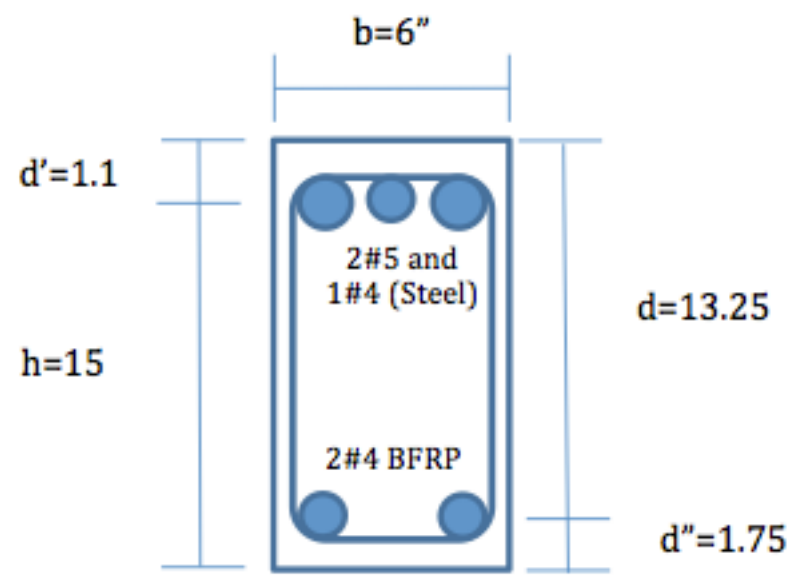




\section{Reinforcement:}

Compression $=2 \# 5$ and $1 \# 4$ steel bars

Tension $=2 \# 4$ BFRP bars

\section{Given:}

$$
\begin{aligned}
& f_{c}^{\prime}=4.5 \mathrm{ksi} \\
& f_{y}=60 \mathrm{ksi} \\
& \beta_{1}=0.825 \\
& E_{\text {frp }}=8 \mathrm{Msi}=8000 \mathrm{ksi} \\
& E_{\text {steel }}=29 \mathrm{Msi} \\
& A \# 4=0.20 \mathrm{in}^{2} \\
& A \# 5=0.31 \mathrm{in}^{2}
\end{aligned}
$$

BFRP load for 1 layer/unit width $=1162 / 0.75=1550 \mathrm{lb}($ width $=0.75 \mathrm{inch}$, Table 5.5)

\section{Solution: Assumed tension failure}

From equilibrium: compression $=$ tension

$$
\begin{gathered}
\mathrm{C}_{\text {concrete }}=\mathrm{T}_{\text {frp }} \\
0.85 f_{c}^{\prime} \mathrm{ab}+\mathrm{A}_{\mathrm{s}} f_{s}=\mathrm{A}_{\text {frp }} f_{\text {frp }} \\
C_{\text {concrete }}=0.85 \times 4500 \times 0.825 \times c \times 6+[(0.31 \times 2)+(0.2 \times 1)] 60000 \\
\mathrm{~T}_{\text {frp }}=(0.2 \times 2) \times 105000 \\
c=0.380 \text { inch, } \quad \mathrm{a}=0.315 \text { inch } \\
56,395 \mathrm{lb}=42,000 \mathrm{lb} \quad \rightarrow \text { Tension Failure }
\end{gathered}
$$


Moment at which at first crack occur:

$$
\begin{aligned}
& M_{c r}=f_{c r} \times \frac{I}{y} \\
= & 7.5 \sqrt{4500} \times \frac{b d^{2}}{6} \\
= & 7.5 \sqrt{4500} \times 6 * \frac{15^{2}}{6} \\
= & 113,200.94 \mathrm{lb} . \mathrm{in} \\
= & 9.433 \mathrm{kip} . \mathrm{ft}
\end{aligned}
$$

Load at which at first crack occur: $\operatorname{span}=60$ inch $=\mathbf{5} \mathrm{ft}$

$$
\begin{gathered}
P_{c r}=9.433 \times \frac{4}{5} \\
\quad=7.55 \mathrm{kip}
\end{gathered}
$$

Resisting moment for BFRP wrapped beam:

$$
\begin{gathered}
M_{n}=T_{\text {tot }}[0.85 d] \\
\mathrm{M}_{\mathrm{n}}=42,000[0.85 \times 13.25] \\
\mathrm{M}_{\mathrm{n}}=39.42 \mathrm{kip} . \mathrm{ft}
\end{gathered}
$$

From Four point bending test: $\operatorname{span}=60 \mathrm{inch}=5 \mathrm{ft}$

$$
\begin{aligned}
P_{n} & =4 M_{n} / \text { span } \\
& =4 \times \frac{39.42}{5} \\
& =31.54 \mathrm{kip}
\end{aligned}
$$

Hence, Maximum load and resisting moment from theory are 31.54 kip and 39.42 kip.ft, 
respectively. These values are within $6.5 \%$ of the theoretical value (33.60 kips vs. 31.54 kips or 42 kip.ft vs. 39.43 kip.ft) as per Table 4.3.

Example 5: Concrete beam reinforced with \#4 BFRP bar and bonded with 1 layer of BFRP

fabric

Dimension:

$$
\begin{aligned}
& \mathrm{b}=6 \text { inch } \\
& \mathrm{h}=15 \text { inch } \\
& \mathrm{d}=13.25 \text { inch } \\
& \mathrm{d}^{\prime}=1.0625^{\prime} \cong 1.1 \text { inch } \\
& \mathrm{d}=1.75 "
\end{aligned}
$$

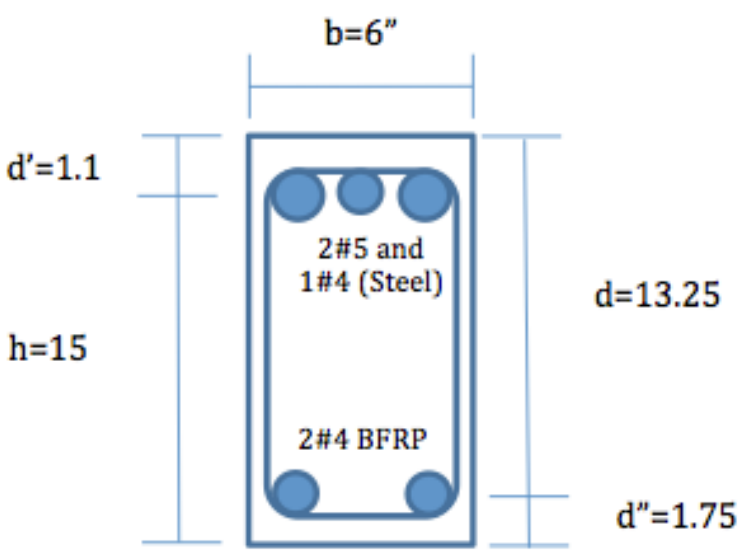

\section{Reinforcement:}

Compression $=2 \# 5$ and $1 \# 4$ steel bars

Tension= 2\#4 BFRP bars

\section{Given:}

$$
\begin{aligned}
& f_{c}^{\prime}=4.5 \mathrm{ksi} \\
& f_{y}=60 \mathrm{ksi} \\
& \beta_{1}=0.825 \\
& E_{\text {frp }}=8 \mathrm{Msi}=8000 \mathrm{ksi} \\
& E_{\text {steel }}=29 \mathrm{Msi} \\
& A \# 4=0.20 \mathrm{in}^{2} \\
& A \# 5=0.31 \mathrm{in}^{2}
\end{aligned}
$$

BFRP load for 1 layer/unit width $=1162 / 0.75=1550 \mathrm{lb}($ width $=0.75$ inch, Table 5.5) 
From equilibrium: compression $=$ tension

$$
\begin{gathered}
\mathrm{C}_{\text {concrete }}=\mathrm{T}_{\text {frp }} \\
0.85 f_{c}^{\prime} \mathrm{ab}+\mathrm{A}_{\mathrm{s}} f_{s}=\left(\mathrm{A}_{\text {frp }} f_{\text {frp }}\right)_{\text {bar }}+\left(\mathrm{A}_{\text {frp }} f_{\text {frp }}\right)_{\text {fabric }} \\
C_{\text {concrete }}=0.85 \times 4500 \times 0.825 \times c \times 6+[(0.31 \times 2)+(0.2 \times 1)] 60000 \\
\mathrm{~T}=\mathrm{T}_{1}+\mathrm{T}_{2}=(0.11 \times 2) \times 105000+(1 \times 6 \times 0.02) *\left(\frac{1150}{0.02}\right) \\
T_{1}=A_{s t} f_{y} \\
T_{2}=n b A_{\text {frp }} f_{\text {frp }} \\
c=0.0159 \text { inch, } \quad \mathrm{a}=0.0131 \text { inch } \\
49,501 \mathrm{lb}=48,900 \mathrm{lb} \quad \rightarrow \text { Tension Failure }
\end{gathered}
$$

Resisting moment for BFRP wrapped beam:

$$
\begin{gathered}
M_{n}=T_{\text {tot }}[0.85 d] \\
\mathrm{M}_{\mathrm{n}}=48,900 \quad[0.85 \times 13.25] \\
\mathrm{M}_{\mathrm{n}}=45.89 \text { kip.ft }
\end{gathered}
$$

From Four point bending test: $\operatorname{span}=60 \mathrm{inch}=5 \mathrm{ft}$

$$
\begin{aligned}
P_{n} & =4 M_{n} / \text { span } \\
& =4 \times \frac{45.89}{5} \\
& =36.72 \mathrm{kip}
\end{aligned}
$$

Hence, Maximum load and resisting moment from theory are 36.72 kip and 45.89 kip.ft, respectively. These values are within $9.6 \%$ of the theoretical value (36.72 kips vs. 40.26 kips or 45.89 kip.ft vs. 50.33 kip.ft) as per Table 4.3 . 
Example 6: Concrete beam reinforced with \#4 BFRP bar and bonded with 2 layers of

\section{BFRP fabric}

\section{Dimension:}

$$
\begin{aligned}
& \mathrm{b}=6 \text { inch } \\
& \mathrm{h}=15 \mathrm{inch} \\
& \mathrm{d}=13.25 \mathrm{inch} \\
& \mathrm{d}^{\prime}=1.0625 " \cong 1.1 \mathrm{inch} \\
& \mathrm{d}^{\prime \prime}=1.75^{\prime}
\end{aligned}
$$

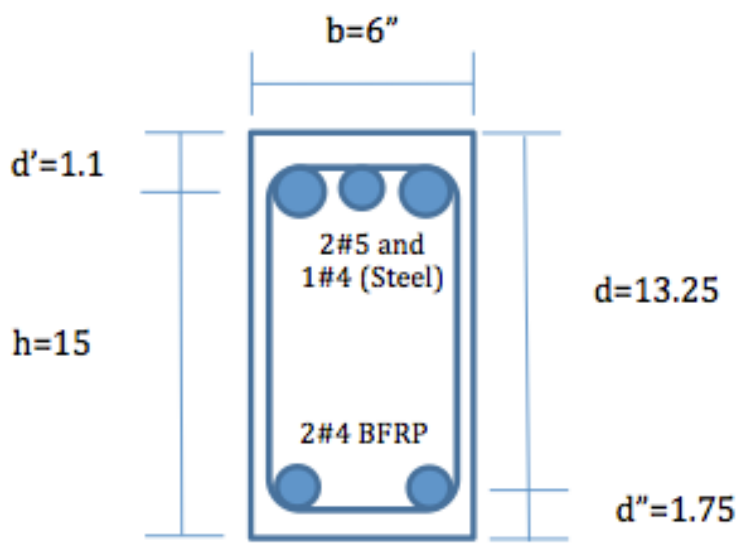

\section{Reinforcement:}

Compression $=2 \# 5$ and $1 \# 4$ steel bars

Tension $=2 \# 4$ BFRP bars

\section{Given:}

$$
\begin{aligned}
& f_{c}^{\prime}=4.5 \mathrm{ksi} \\
& f_{y}=60 \mathrm{ksi} \\
& \beta_{1}=0.825 \\
& E_{\text {frp }}=8 \mathrm{Msi}=8000 \mathrm{ksi} \\
& E_{\text {steel }}=29 \mathrm{Msi} \\
& A \# 4=0.20 \mathrm{in}^{2} \\
& A \# 5=0.31 \mathrm{in}^{2}
\end{aligned}
$$

BFRP load for 1 layer/unit width $=1162 / 0.75=1550 \mathrm{lb}($ width $=0.75 \mathrm{inch}$, Table 5.5)

From equilibrium: compression $=$ tension

$$
\mathrm{C}_{\text {concrete }}=\mathrm{T}_{\text {frp }}
$$




$$
\begin{gathered}
0.85 f_{c}^{\prime} \mathrm{ab}+\mathrm{A}_{\mathrm{s}} f_{s}=\left(\mathrm{A}_{f r p} f_{f r p}\right)_{b a r}+\left(\mathrm{A}_{f r p} f_{\text {frp }}\right)_{\text {fabric }} \\
C_{\text {concrete }}=0.85 \times 4500 \times 0.825 \times c \times 6+[(0.31 \times 2)+(0.2 \times 1)] 60000 \\
\mathrm{~T}=\mathrm{T}_{1}+\mathrm{T}_{2}=(0.11 \times 2) \times 105000+(2 \times 6 \times 0.02) *\left(\frac{1150}{0.02}\right) \\
T_{1}=A_{\text {st }} f_{y} \\
T_{2}=n b A_{\text {frp }} f_{\text {frp }} \\
c=0.349 \text { inch, } \quad \mathrm{a}=0.288 \text { inch } \\
55,808 \mathrm{lb}=55,800 \mathrm{lb} \rightarrow \text { Tension Failure }
\end{gathered}
$$

Resisting moment for BFRP wrapped beam:

$$
\begin{gathered}
M_{n}=T_{t o t}[0.85 d] \\
\mathrm{M}_{\mathrm{n}}=55,800[0.85 \times 13.25] \\
\mathrm{M}_{\mathrm{n}}=52,37 \mathrm{kip} . \mathrm{ft}
\end{gathered}
$$

From Four point bending test: $\operatorname{span}=60 \mathrm{inch}=5 \mathrm{ft}$

$$
\begin{gathered}
P_{n}=4 M_{n} / \text { span } \\
=4 \times \frac{52.37}{5} \\
=41.90 \mathrm{kip}
\end{gathered}
$$

Hence, Maximum load and resisting moment from theory are 41.90 kip and 52.37 kip.ft, respectively. Experimental are within $9.8 \%$ of the theoretical values $(37.80 \mathrm{kips}$ vs. 41.90 kips or 47.25 kip.ft vs. 52.37 kip.ft) as per Table 4.3. 
Example 7: Base concrete beam reinforced with \#5 BFRP bar

Dimension:

$b=6$ inch

$\mathrm{h}=15$ inch

$\mathrm{d}=13.2 \mathrm{inch}$

$\mathrm{d}=1.0625 " \cong 1.1 \mathrm{inch}$

$\mathrm{d} "=1.8 "$

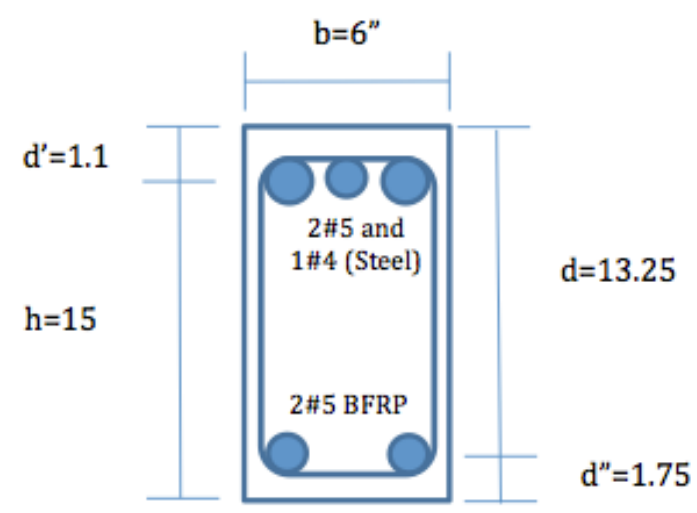

\section{Reinforcement:}

Compression $=2 \# 5$ and $1 \# 4$ steel bars

Tension $=2 \# 4$ BFRP bars

\section{Given:}

$$
\begin{aligned}
& f_{c}^{\prime}=4.5 \mathrm{ksi} \\
& f_{y}=60 \mathrm{ksi} \\
& \beta_{1}=0.825 \\
& E_{f r p}=8 \mathrm{Msi}=8000 \mathrm{ksi} \\
& E_{\text {steel }}=29 \mathrm{Msi} \\
& A \# 4=0.20 \mathrm{in}^{2} \\
& A \# 5=0.31 \mathrm{in}^{2}
\end{aligned}
$$

BFRP load for 1 layer/unit width $=1162 / 0.75=1550 \mathrm{lb}($ width $=0.75 \mathrm{inch}$, Table 5.5)

From equilibrium: compression $=$ tension

$$
\begin{gathered}
\mathrm{C}_{\text {concrete }}=\mathrm{T}_{\text {frp }} \\
0.85 f_{c}^{\prime} \mathrm{ab}+\mathrm{A}_{\mathrm{s}} f_{s}=\left(\mathrm{A}_{\text {frp }} f_{\text {frp }}\right)_{\text {bar }}+\left(\mathrm{A}_{\text {frp }} f_{\text {frp }}\right)_{\text {fabric }} \\
C_{\text {concrete }}=0.85 \times 4500 \times 0.825 \times c \times 6+[(0.31 \times 2)+(0.2 \times 1)] 60000
\end{gathered}
$$




$$
\begin{gathered}
\mathrm{T}_{\text {frp }}=(0.31 \times 2) \times 105000 \\
c=0.840 \text { inch, } \quad \mathrm{a}=0.693 \text { inch } \\
65,104 \mathrm{lb}=65,100 \mathrm{lb} \quad \rightarrow \text { Tension Failure }
\end{gathered}
$$

Resisting moment for BFRP wrapped beam:

$$
\begin{gathered}
M_{n}=T_{t o t}[0.85 d] \\
\mathrm{M}_{\mathrm{n}}=65,100[0.85 \times 13.25] \\
\mathrm{M}_{\mathrm{n}}=61.10 \mathrm{kip} . \mathrm{ft}
\end{gathered}
$$

From three point bending test: $\operatorname{span}=60$ inch $=5 \mathrm{ft}$

$$
\begin{aligned}
P_{n} & =4 M_{n} / \text { span } \\
& =4 \times \frac{61.10}{5} \\
& =48.88 \mathrm{kip}
\end{aligned}
$$

Hence, Maximum load and resisting moment from theory are 48.88 kip and 61.01 kip.ft, respectively. These values are within $8 \%$ of the theoretical value (48.88 kips vs. 52.80 kips or 61 kip.ft vs. 66 kip.ft) as per Table 4.3.

Example 8: Concrete beam reinforced with \#5 BFRP bar and bonded with 1 layer of BFRP

fabric

Dimension:

$b=6$ inch

$\mathrm{h}=15$ inch

$\mathrm{d}=13.2$ inch

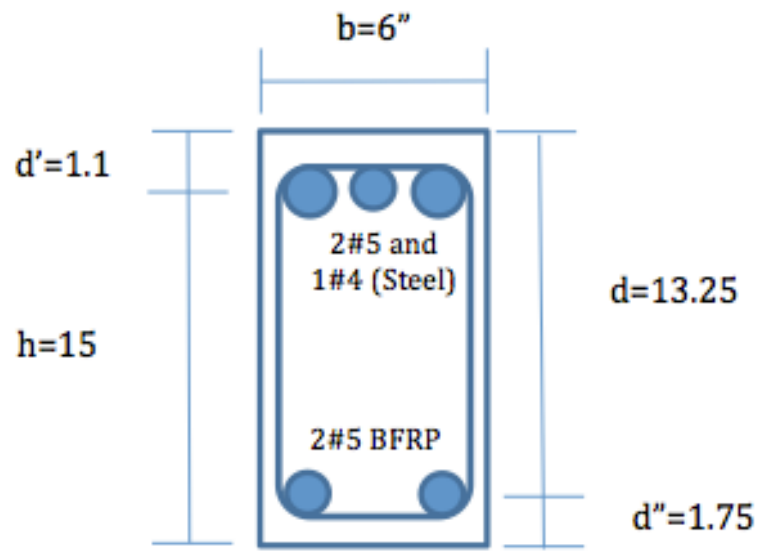




$$
\begin{aligned}
& d^{\prime}=1.0625 " \cong 1.1 \text { inch } \\
& d^{\prime \prime}=1.8 "
\end{aligned}
$$

\section{Reinforcement:}

Compression $=2 \# 5$ and $1 \# 4$ steel bars

Tension $=2 \# 4$ BFRP bars

\section{Given:}

$$
\begin{aligned}
& f_{c}^{\prime}=4.5 \mathrm{ksi} \\
& f_{y}=60 \mathrm{ksi} \\
& \beta_{1}=0.825 \\
& E_{f r p}=8 \mathrm{Msi}=8000 \mathrm{ksi} \\
& E_{\text {steel }}=29 \mathrm{Msi} \\
& A \# 4=0.20 \mathrm{in}^{2} \\
& A \# 5=0.31 \mathrm{in}^{2}
\end{aligned}
$$

BFRP load for 1 layer/unit width $=1162 / 0.75=1550 \mathrm{lb}($ width $=0.75 \mathrm{inch}$, Table 5.5)

From equilibrium: compression $=$ tension

$$
\begin{gathered}
\mathrm{C}_{\text {concrete }}=\mathrm{T}_{\text {frp }} \\
0.85 f_{c}^{\prime} \mathrm{ab}+\mathrm{A}_{\mathrm{s}} f_{s}=\left(\mathrm{A}_{\text {frp }} f_{\text {frp }}\right)_{\text {bar }}+\left(\mathrm{A}_{\text {frp }} f_{\text {frp }}\right)_{\text {fabric }} \\
C_{\text {concrete }}=0.85 \times 4500 \times 0.825 \times c \times 6+[(0.31 \times 2)+(0.2 \times 1)] 60000 \\
\mathrm{~T}=\mathrm{T}_{1}+\mathrm{T}_{2}=(0.31 \times 2) \times 105000+(1 \times 6 \times 0.02) *\left(\frac{1150}{0.02}\right) \\
T_{1}=A_{s t} f_{y} \\
T_{2}=n b A_{\text {frp }} f_{\text {frp }}
\end{gathered}
$$




$$
\begin{array}{cc}
c=1.204 \text { inch, } & \mathrm{a}=0.993 \text { inch } \\
73,211 \mathrm{lb}=72,000 \mathrm{lb} & \rightarrow \text { Tension Failure }
\end{array}
$$

Resisting moment for BFRP wrapped beam:

$$
\begin{gathered}
M_{n}=T_{t o t}[0.85 d] \\
\mathrm{M}_{\mathrm{n}}=72,000[0.85 \times 13.25] \\
\mathrm{M}_{\mathrm{n}}=67.58 \mathrm{kip.ft}
\end{gathered}
$$

From Four point bending test: $\operatorname{span}=60 \mathrm{inch}=5 \mathrm{ft}$

$$
\begin{aligned}
P_{n} & =4 M_{n} / \text { span } \\
& =4 \times \frac{67.58}{5} \\
& =54.06 \mathrm{kip}
\end{aligned}
$$

Hence, Maximum load and resisting moment from theory are 54.06 kip and 67.58 kip.ft, respectively. These values are within $24 \%$ of the theoretical value (54.06 kips vs. 66.77 kips or 67.58 kip.ft vs. 83.46 kip.ft) as per Table 4.3 .

Example 9: Concrete beam reinforced with \#5 BFRP bar and bonded with 2 layer of BFRP

fabric

\section{Dimension:}

$$
\begin{aligned}
& \mathrm{b}=6 \text { inch } \\
& \mathrm{h}=15 \text { inch } \\
& \mathrm{d}=13.2 \mathrm{inch} \\
& \mathrm{d}^{\prime}=1.0625^{\prime} \cong 1.1 \mathrm{inch}
\end{aligned}
$$

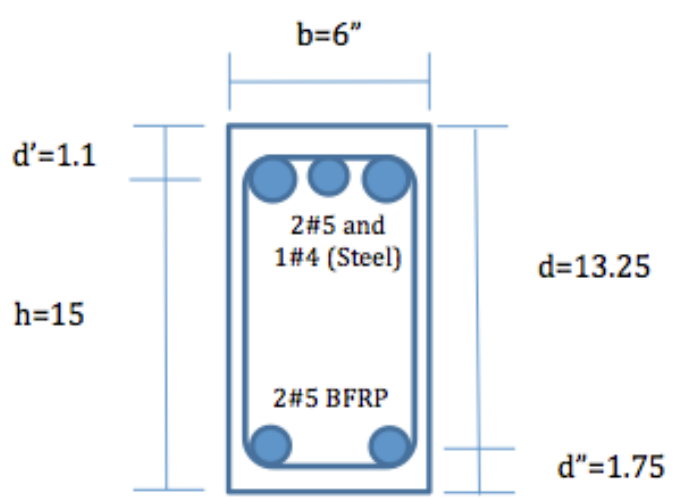




$$
\mathrm{d} "=1.8 "
$$

\section{Reinforcement:}

Compression $=2 \# 5$ and $1 \# 4$ steel bars

Tension $=2 \# 4$ BFRP bars

\section{Given:}

$$
\begin{aligned}
& f_{c}^{\prime}=4.5 \mathrm{ksi} \\
& f_{y}=60 \mathrm{ksi} \\
& \beta_{1}=0.825 \\
& E_{\text {frp }}=8 \mathrm{Msi}=8000 \mathrm{ksi} \\
& E_{\text {steel }}=29 \mathrm{Msi} \\
& A \# 4=0.20 \mathrm{in}^{2} \\
& A \# 5=0.31 \mathrm{in}^{2}
\end{aligned}
$$

BFRP load for 1 layer/unit width $=1162 / 0.75=1550 \mathrm{lb}($ width $=0.75 \mathrm{inch}$, Table 5.5)

From equilibrium: compression $=$ tension

$$
\begin{gathered}
\mathrm{C}_{\text {concrete }}=\mathrm{T}_{\text {frp }} \\
0.85 f_{c}^{\prime} \mathrm{ab}+\mathrm{A}_{\mathrm{s}} f_{s}=\left(\mathrm{A}_{\text {frp }} f_{\text {frp }}\right)_{\text {bar }}+\left(\mathrm{A}_{\text {frp }} f_{\text {frp }}\right)_{\text {fabric }} \\
C_{\text {concrete }}=0.85 \times 4500 \times 0.825 \times c \times 6+[(0.31 \times 2)+(0.2 \times 1)] 60000 \\
\mathrm{~T}=\mathrm{T}_{1}+\mathrm{T}_{2}=(0.31 \times 2) \times 105000+(2 \times 6 \times 0.02) *\left(\frac{1150}{0.02}\right) \\
T_{1}=A_{s t} f_{y} \\
T_{2}=n b A_{\text {frp }} f_{\text {frp }} \\
c=1.497 \text { inch, } \quad \mathrm{a}=1.235 \mathrm{inch}
\end{gathered}
$$




$$
78,544 \mathrm{lb}=78,900 \mathrm{lb} \quad \rightarrow \text { Tension Failure }
$$

\section{Resisting moment for BFRP wrapped beam:}

$$
\begin{gathered}
M_{n}=T_{\text {tot }}[0.85 d] \\
\mathrm{M}_{\mathrm{n}}=78,900[0.85 \times 13.25] \\
\mathrm{M}_{\mathrm{n}}=74.05 \mathrm{kip} . \mathrm{ft}
\end{gathered}
$$

From Four point bending test: $\operatorname{span}=60$ inch $=5 \mathrm{ft}$

$$
\begin{aligned}
P_{n} & =4 M_{n} / s p a n \\
& =4 \times \frac{74.05}{5} \\
& =59.24 \mathrm{kip}
\end{aligned}
$$

Hence, Maximum load and resisting moment from theory are 59.24 kip and 74.05kip.ft, respectively. Experimental values are within $24 \%$ of the theoretical values (62.70 kips vs. 77.83 kips or 78.38 kip.ft vs. 97.28 kip.ft) as per Table 4.3.

\subsection{Summary}

BFRP wrapped beams showed significant increase in strength as compared to the base beam. Maximum increase in the load and bending moment capacity of the beams with 2 and 3 layers of BFRP wrap is $58 \%$ and $71 \%$, respectively. Deflection and crack-widths were noted to decrease with the bonding of additional FRP fabrics.

Beams were tested with both \#4 and \#5 internal FRP bars and external FRP fabrics ( 1 and 2 layers) in the tension zone. Beams with larger diameter bars carried higher failure loads as compared to those with smaller diameter bars (\#4) for similar number of FRP fabrics (1 or 2 
layers). Increasing the number of FRP fabrics resulted in the corresponding increase in strength and stiffness. Increase in stiffness of the beam resulted in a reduction of deflection and crackwidth.

From the above, it is evident that BFRPs can be an effective alternative reinforcements to steel and glass FRP reinforcement in concrete beams. 


\section{Evaluation of Concrete Cylinders Wrapped with BFRP}

\subsection{Introduction}

This chapter describes the materials and equipment used to conduct tests on basalt FRP fabric coupon specimens and concrete cylinders wrapped with FRP fabrics to evaluate confinement effects. Non-wrapped concrete cylinders were used as control specimens in order to evaluate the increase in strength of wrapped specimens.

\subsection{Materials}

\subsubsection{Concrete}

The concrete used in this study was prepared in two batches. Batch 1 was prepared and mixed in WVU concrete lab with a compressive strength of 4000-psi. Concrete was mixed using a concrete mixer (Figure 5.4). For hand concrete mixing: cement, fine aggregate, coarse aggregate and water were used in the ratio of $23,75,100$, and 12 by weight, respectively in a 3 (cu.ft) capacity concrete mixer (Figure 5.1). Batch 2 specimens were prepared from ready-mix concrete with a compressive strength of 6000-psi. Both Batch 1 and Batch 2 specimens were used to evaluate confinement effect off basalt fabric on concrete cylinders.. Each of the concrete pour resulted in preparation of 60 cylinders, with dimensions measuring 6"x12". They were cured for 28 days to achieve their characteristic strength (Figure 5.2). 


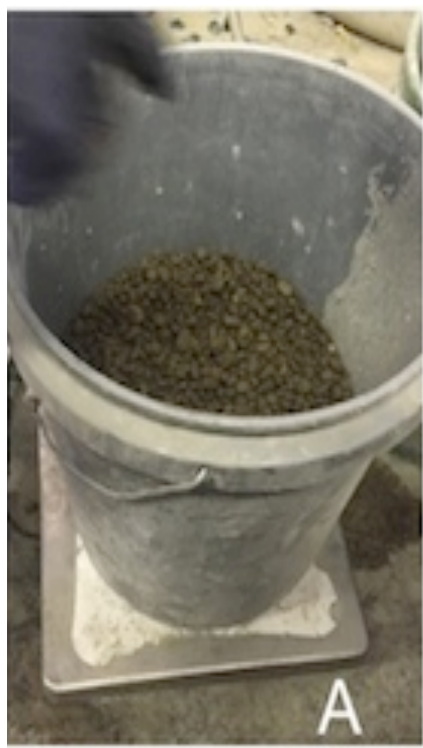

A. Coarse Aggregate

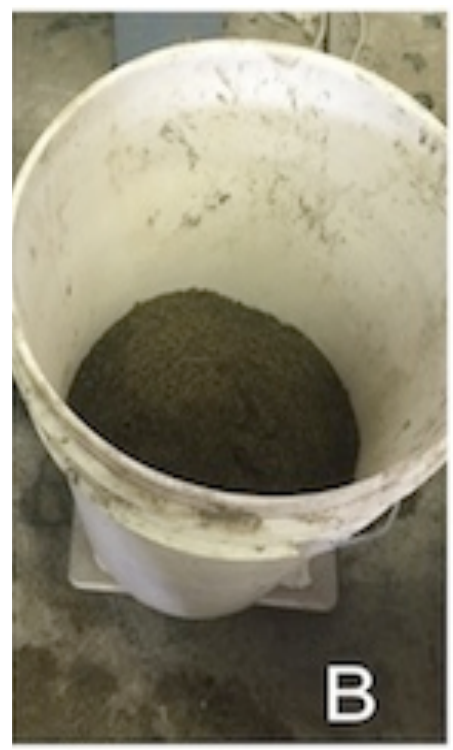

B. Fine Aggregate

Figure 5.1: Coarse and Fine Aggregates Used for Concrete Preparation

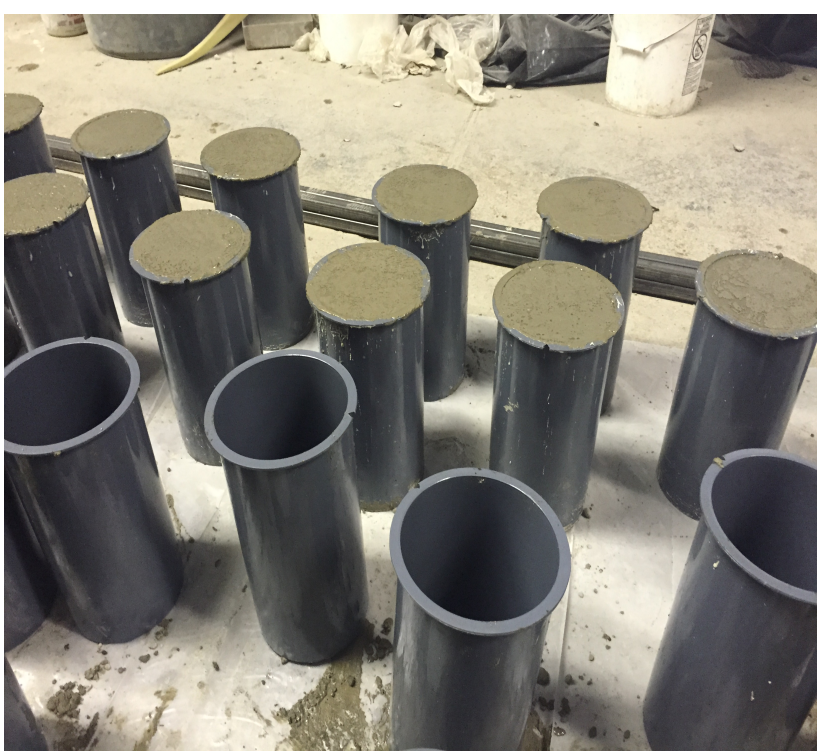

Figure 5.2: 6"x12" Concrete Cylinder

\subsubsection{Basalt Fabric}

The basalt fabric was available in the form of rolls from the manufacturer. (Raw Energy Material 
Corporation, Florida) and consists of unidirectional fibers $\left(0^{\circ}\right)$.

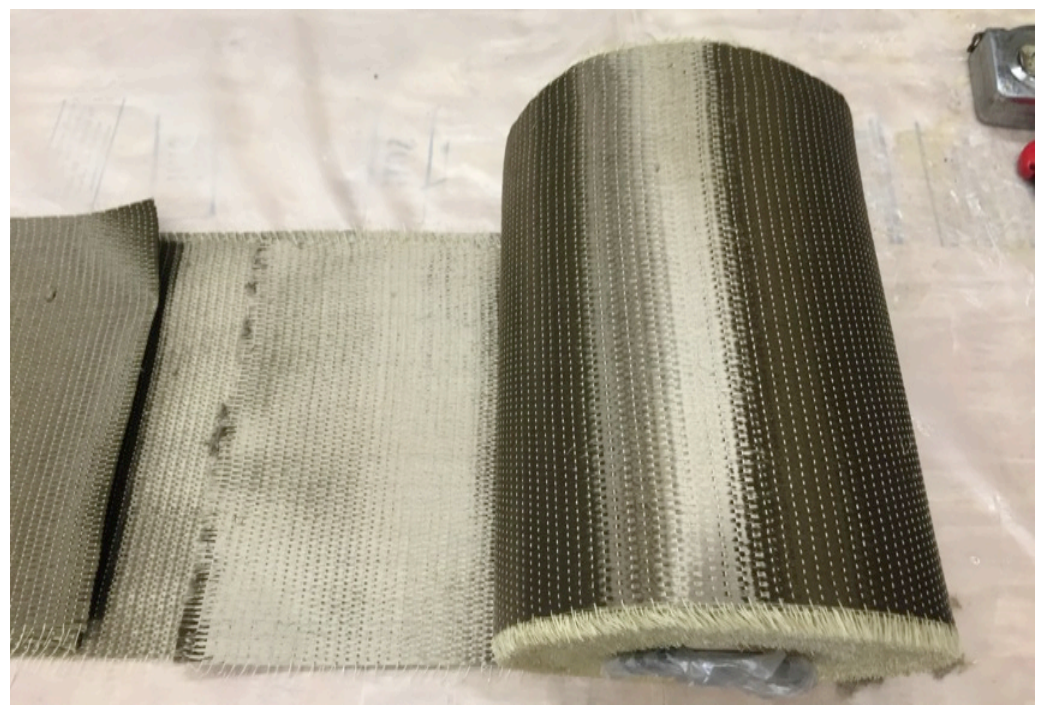

Figure 5.3: Basalt Fabric

\subsubsection{Resin/Hardener}

The description for epoxy resin and hardener used in this study is described earlier in Chapter 4 under section 4.2.5

\subsection{Equipment and Test Set-up}

\subsubsection{Concrete Mixer}

A concrete mixer was used to prepare concrete mix in the laboratory. The mixer has a capacity of 3 (cu.ft) and is operated by an elastic motor for the rotating action and a manual wheel for rolling the mixer. 


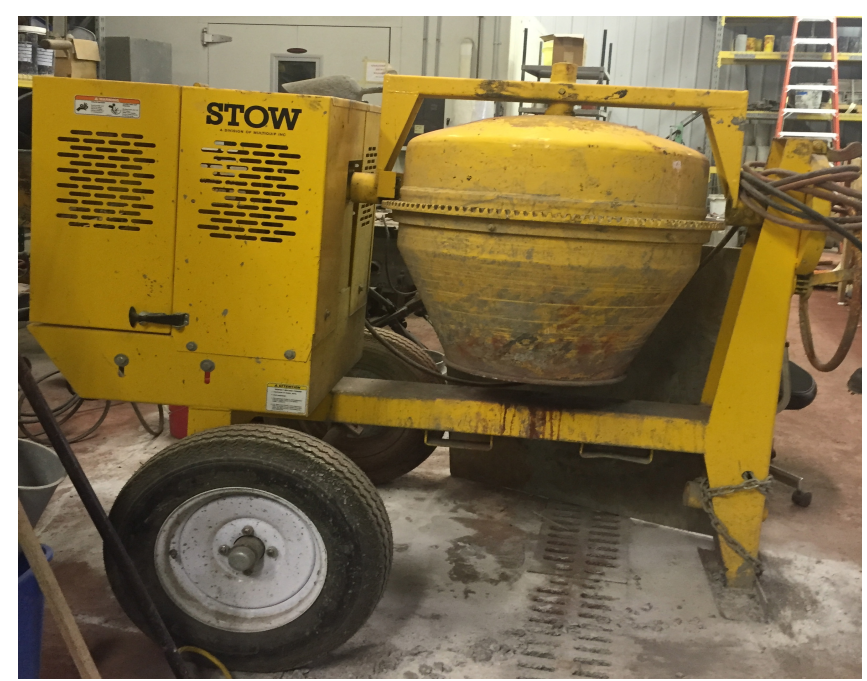

Figure 5.4: Concrete Mixer

\subsubsection{Universal Compression Testing Machine}

The Universal compression-testing machine has a 350 kip capacity and is fitted with two separate load indicator dials for dial reading maximum loads of 50 kips and 350 kips, respectively.
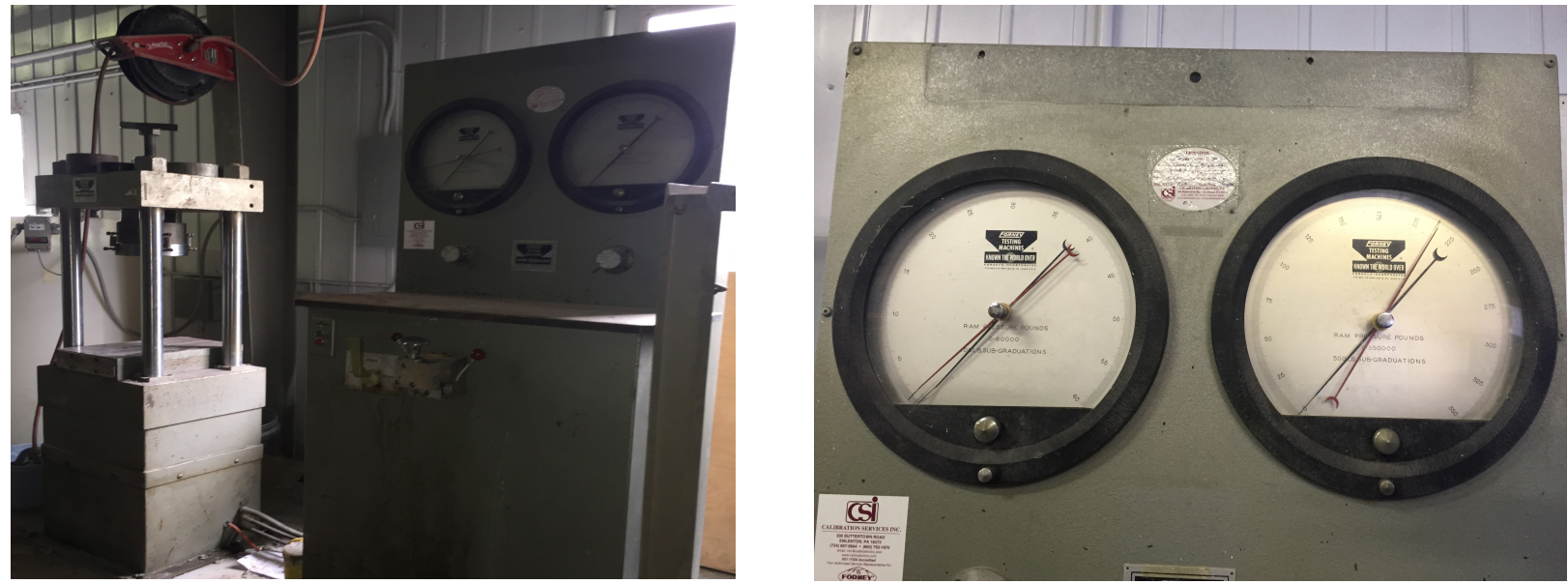

Figure 5.5: Universal Compression Testing Machine (Left) and Dial Gage (Right) 


\subsubsection{Instron Machine}

The Instron machine with a capacity of 22 kips, was used to test the basalt fabric coupons to determine their tensile Strength and Stiffness. These fabrics were used to wrap the concrete cylinders.

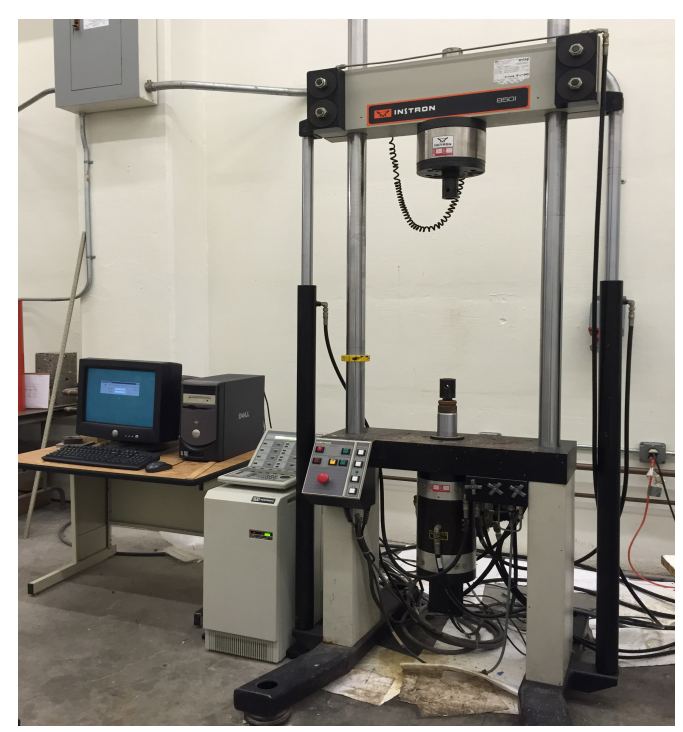

Figure 5.6: Instron Machine

\subsubsection{Gages, Load Cell and Data Acquisition}

Data acquisition system was used to collect and record the test data. It has strain gage cards and high-level cards to record data from load cells and LVDT. The data acquired by the data acquisition system is interrupted by STRAIN SMART software. The data recorded by the data acquisition system can be exported as an excel file by the strain smart software. Strain gages used in the tests were of 350-ohm resistance. M2- Bond adhesive manufactured by Vishay Measurements was used to bond the gages on the fabric. Since the Universal compression-testing machine did not have a provision for continuous measurement of loads, a calibrated load cell with a maximum capacity of 200 kips was used to record the load through the data acquisition. 


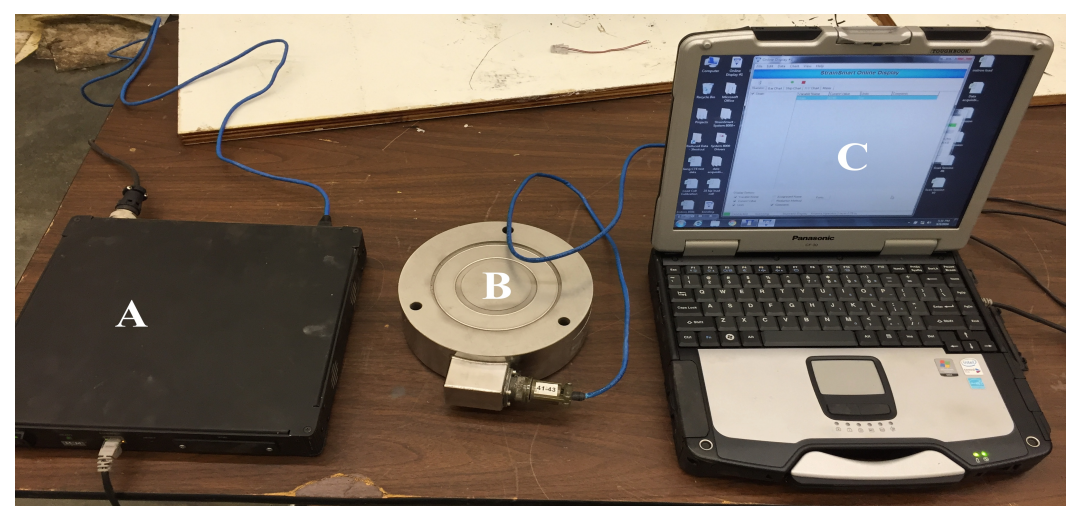

Figure 5.7: Data Acquisition (A\&C) System, and Load Cell (B)

\subsection{Specimen Description}

\subsubsection{Basalt FRP Confined Cylinders}

Concrete cylinders (6"x12") with a compressive strength $f_{c}^{\prime}=4000$ psi (batch 1) and $f_{c}^{\prime}=6000$ psi (batch 2) were used to investigate increase in confinement related strength and stiffness provided by basalt FRP fabrics. Specimens from each batch were attached with two strain gages; one in the axial direction and another in the hoop direction as shown in Figure 5.8. In order to investigate the effect and performance of FRP layers, concrete cylinders were wrapped with 1, 2, and 3 layers of basalt fabrics and tested.

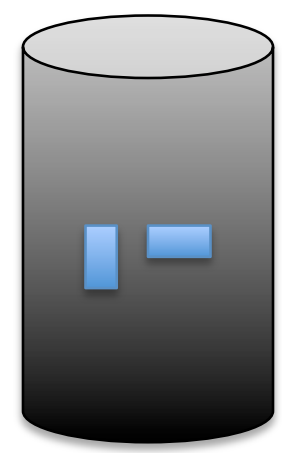

Non-Wrapped Concrete Specimen (Control)

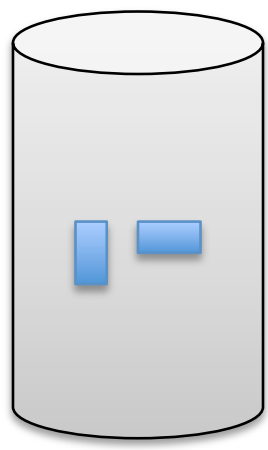

Wrapped Concrete Specimen

Figure 5.8: Test Specimens with Axial and Hoop Gauges 


\subsubsection{Basalt FRP Coupon}

Basalt FRP coupon specimens with unidirectional fibers measuring $1 / 2$ " in width and 12 " in length were tested in tension (Figure 5.9)

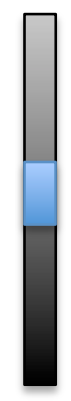

Figure 5.9: Basalt FRP Coupon Specimen

\subsection{Specimens Preparation}

\subsubsection{Concrete Cylinders Preparation}

\subsubsection{Casting and Curing of Concrete Cylinders}

Inner surface of the 6"x12" plastic molds were oiled prior to concrete pouring, in order to make the process of de-molding easier as applying oils would not allow the concrete to bond with the molds.

Concrete cylinders were prepared in the following steps:

1. Concrete cylinder was compacted with adequate number ( 25 times) of tamping in three layers of equal depth.

2. Outer surface of the molds was tapped using a plastic hammer so that voids could escape through the surface.

3. Upper surface of the cylinder was smoothened.

4. Concrete was allowed to set in molds for 24 hours.

5. Compressed air was used to de-mold the cylinders. 
6. Concrete cylinders were placed in curing chambers at ambient temperature for 28 days.

\subsubsection{Wrapping of Concrete Cylinders with Basalt FRP Fabric}

The surface of concrete cylinders were cleaned and dried to avoid voids between the FRP wrap and concrete using rags.

Basalt FRP fabrics were cut to cover the circumference of the cylinder in 1, 2, or 3 layers as per the test configuration with an additional overlap length of 4.0". Epoxy was prepared by mixing the Resin (Part A) and Hardener (Part B) with a volume ratio of 5:1, respectively. Resin and Hardener were mixed together for 5-7 minutes. The epoxy was applied on both the concrete cylinder and the fabric surfaces. The wrapped cylinders were kept in laboratory to cure for at least 48 hours prior to testing. Wrapping procedure used in this study is briefly summarized below.

\section{Wrapping Procedure:}

i. Mix Resin and Hardener with a volume ratio of 5:1, respectively (Figure 5.10).

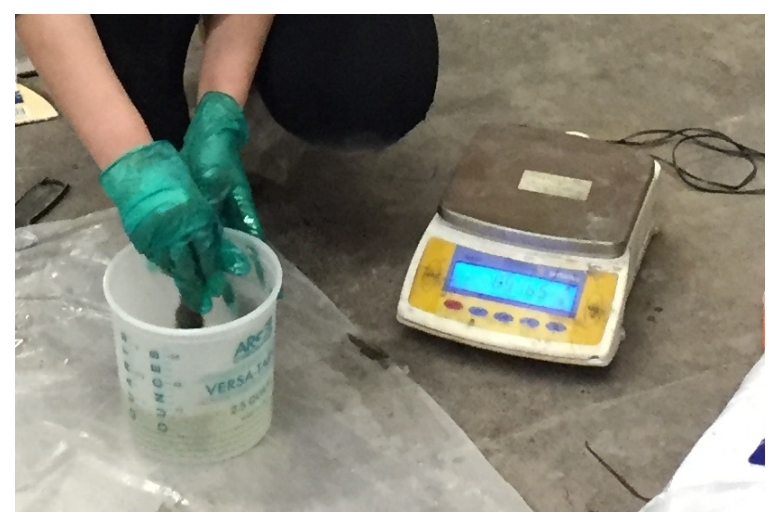

Figure 5.10: Mixing Resin and Hardener

ii. Applying Resin/Hardener on cylinder and basalt FRP fabric. (Figure 5.11) 

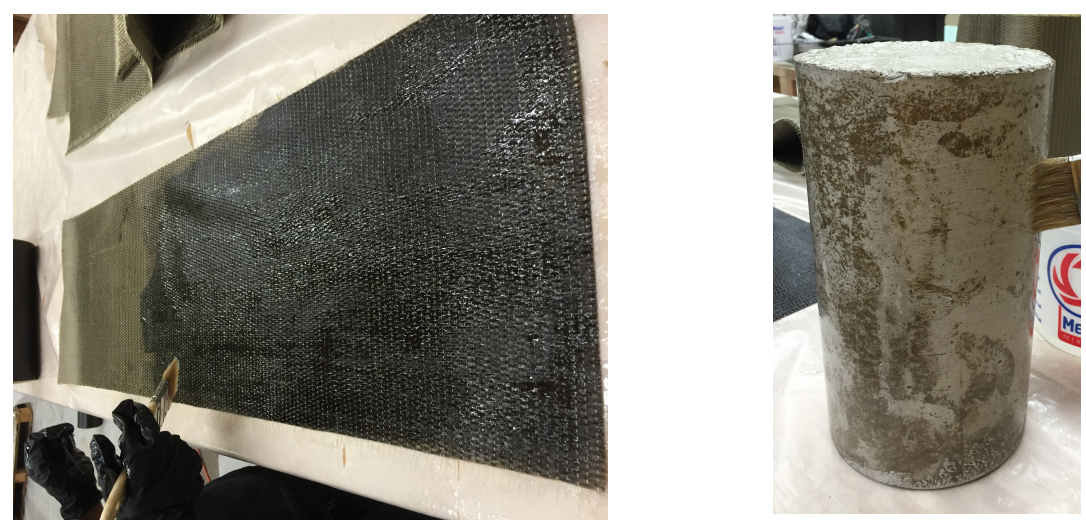

Figure 5.11: Applying Resin/Hardener

iii. Wrapping concrete cylinder with basalt FRP fabric. (Figure 5.12)
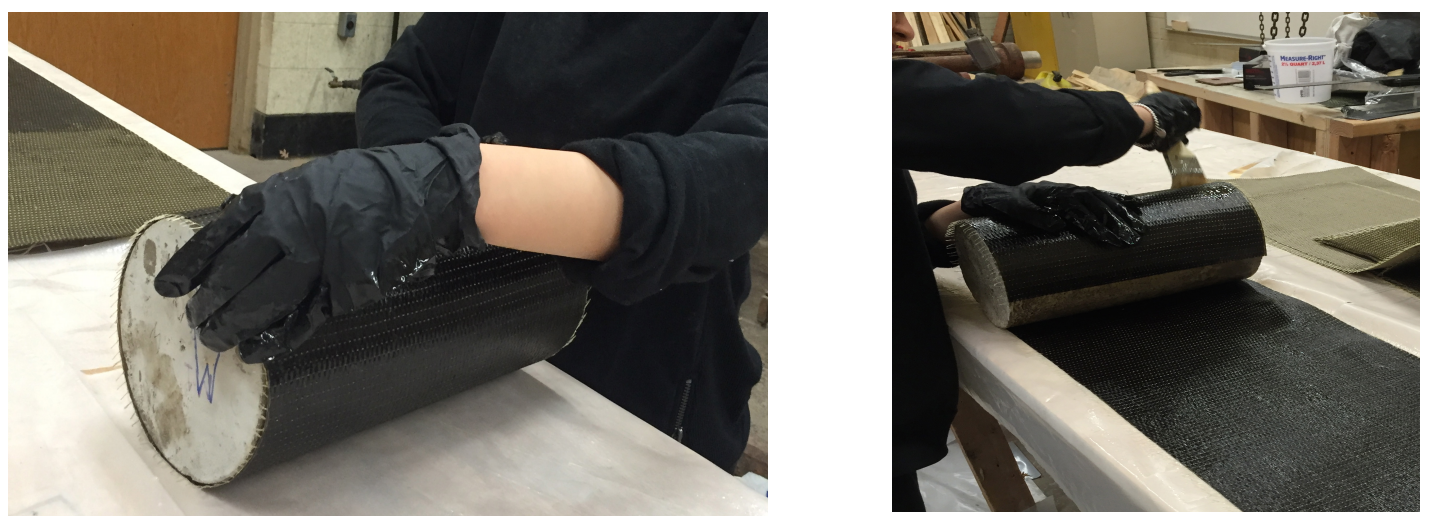

Figure 5.12: Wrapping Concrete Cylinder

iv. Applying Resin/Hardener mix on the outer surface of wrap. (Figure 5.12)

v. Sorting wrapped concrete cylinders at the overlap (seam) position for curing (Figure 5.13)

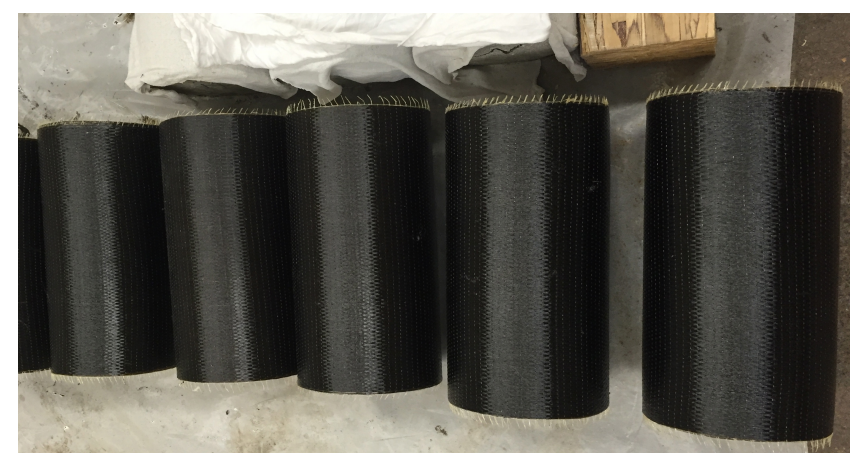

Figure 5.13: Placing Wrapped Concrete Cylinder for Curing (top view) Over Seam 


\subsubsection{Basalt FRP Coupon Preparation}

The following steps were used for preparing basalt FRP Coupons

i. Basalt FRP fabric with dimensions of 6"x13" are cut.

ii. Prepare and mix epoxy resin and hardener with a volume ratio of 5:1.

iii. Apply the epoxy on both sides of the cut fabric.

iv. Stack fabrics over one another (1, 2, 3, and 5 layers).

v. Apply the release agent on steel rectangular plates, so that FRP layers do not get attached to the plates.

vi. Place the fiber fabric between the rectangular plates for curing for at least 48 hours.

vii. Cut test specimens to a dimension of 0.75 " 12 " (12" length along the fiber direction).

viii. Attach tabs on both ends of specimens.

ix. Bond gages at the center of the test specimen (Figure 5.14)

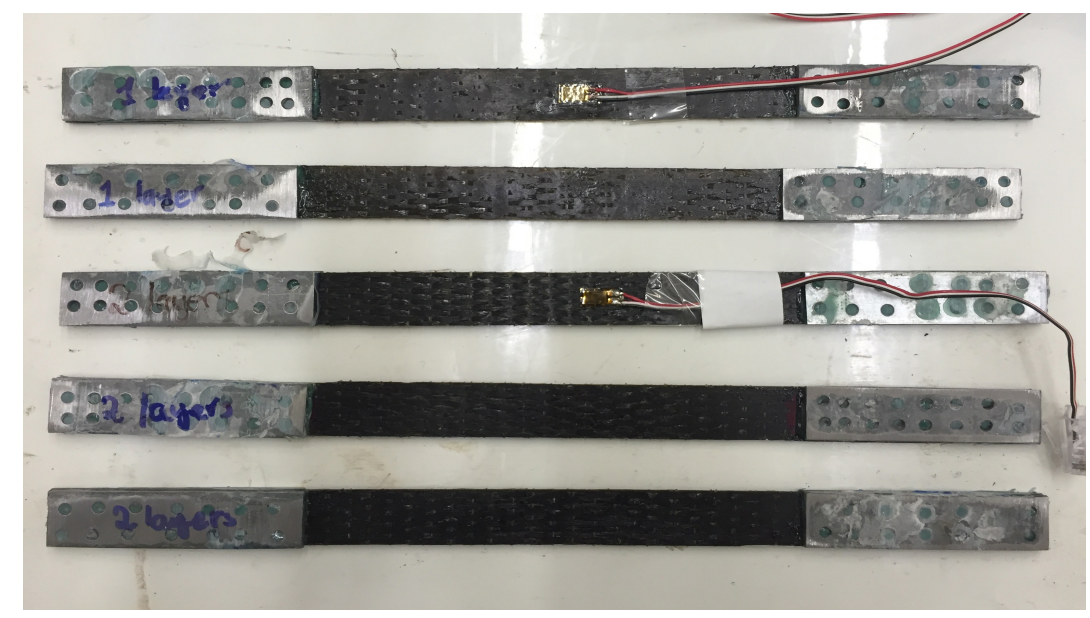

Figure 5.14: Prepared BFRP Coupon Specimens 


\subsection{Test Procedure}

\subsubsection{Axial Compression Test}

Axial compression tests were conducted on concrete cylinder specimens as per ASTM standard. Cylinders were placed at the middle of the lower mounting table of the test machine. Specimens were capped at both top and bottom with steel capping plates that have internal elastomeric pads. Caps were used to ensure that load is distributed uniformly throughout the cylinder. Load cell was placed above the top plate as shown in Figure 5.15.
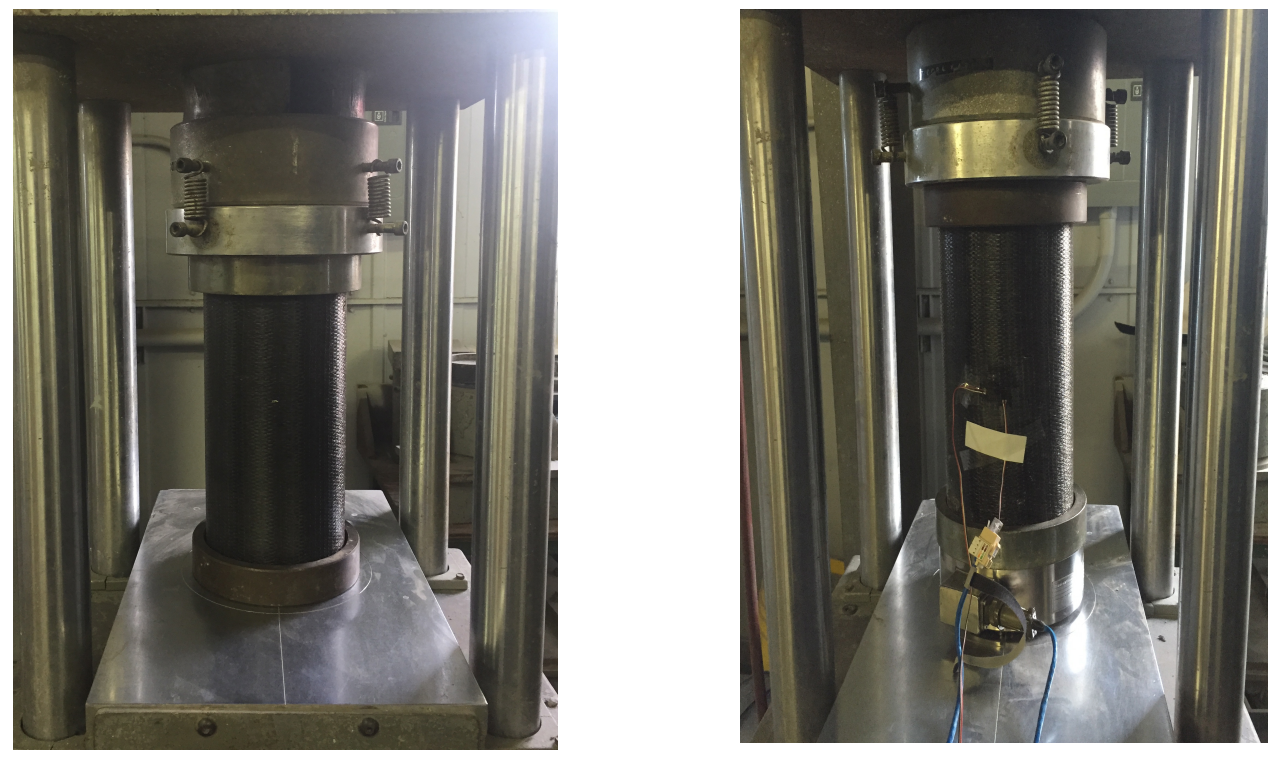

Figure 5.15: Test Set-up for Cylinder Compression Test

\subsubsection{Basalt FRP Coupon Test}

FRP coupon specimens were tested using the Instron machine (Figure 5.6). Specimens were bonded with a strain gage at the center. Perforated steel tabs were attached at the ends of the coupon specimens to facilitate tension testing. 


\subsection{Test Results}

\subsubsection{Axial Compression Test to Determine the Effect of Confinement}

Axial compression tests were preferred to determine the maximum strength, stiffness, and strain in the wrapped and non-wrapped (control specimens) concrete cylinder specimens.

\subsubsection{Ultimate Load}

Compressive tests were evaluated on both non-wrapped and wrapped concrete cylinders and the maximum (ultimate) load capacity was noted from both the dial gage and load cell.

\subsection{Strength of Control Specimens}

The ultimate strength (load capacity) of control (non-wrapped) cylinders (6"x12") is shown in Table 5.2 with compressive strength of $4000 \mathrm{psi}$ and $6000 \mathrm{psi}$. An average of 3 compression tests were conducted on the specimens from each batch as shown in Table 5.2. An example, designation $\mathrm{B} 1-\mathrm{C} 1$ refers to Batch $1\left(f_{c}^{\prime}=4000 \mathrm{psi}\right)$, control specimen (C- without wrapping) and number 1. Similarly, B2-C1 refers to Batch $2\left(f_{c}^{\prime}=6000 \mathrm{psi}\right)$, and control specimen (C- without wrapping), and number 1. 
Table 5.2: Strength of Control Specimens

\begin{tabular}{|c|c|c|c|c|c|c|}
\hline \multirow[t]{2}{*}{ No. } & \multirow[t]{2}{*}{ Batch } & \multirow[t]{2}{*}{ Description } & $\begin{array}{c}\text { Axial } \\
\text { Strength }\end{array}$ & $\begin{array}{l}\text { Axial } \\
\text { Stress }\end{array}$ & $\begin{array}{l}\text { Average Axial } \\
\text { Strength }\end{array}$ & $\begin{array}{c}\text { Average } \\
\text { Axial Stress }\end{array}$ \\
\hline & & & (lbs) & (psi) & (lbs) & (psi) \\
\hline 1 & \multirow{3}{*}{ Batch 1} & B1-C1 & 113 & 3997 & \multirow{3}{*}{116.5} & \multirow{3}{*}{4120} \\
\hline 2 & & $\mathrm{~B} 1-\mathrm{C} 2$ & 116.5 & 4120 & & \\
\hline 3 & & B1-C3 & 120 & 4244 & & \\
\hline 4 & \multirow{3}{*}{ Batch 2} & $\mathrm{~B} 2-\mathrm{C} 1$ & 170 & 6013 & \multirow{3}{*}{179} & \multirow{3}{*}{6331} \\
\hline 5 & & B2-C2 & 187 & 6614 & & \\
\hline 6 & & B2-C3 & 180 & 6366 & & \\
\hline
\end{tabular}

The compressive strength of the tested plain control specimens batches are:

Batch 1, $f_{c}^{\prime}=4120$ psi

Batch 2, $f_{c}^{\prime}=6331 \mathrm{psi}$

\subsection{Strength of Wrapped Specimens}

Wrapped specimens were tested in axial compression and the ultimate strength (maximum load) is shown in Tables 5.3 and 5.4. Specimens were wrapped in $0^{\circ}$ direction along the circumference as mentioned in the previous sections.

Table 5.3: Compressive Strength of Wrapped Cylinders from Batch 1

\begin{tabular}{|c|c|c|c|c|c|c|c|}
\hline \multirow{2}{*}{$\begin{array}{c}\text { Number } \\
\text { of } \\
\text { Layers }\end{array}$} & $\begin{array}{c}\text { Axial } \\
\text { Strength }\end{array}$ & Stress & $\begin{array}{l}\text { Avg. } \\
\text { Stress }\end{array}$ & \multirow{2}{*}{$\begin{array}{c}\text { Strength } \\
\text { Increase } \\
(\%)\end{array}$} & \multirow{2}{*}{$\begin{array}{c}\text { Avg. } \\
\text { Strength } \\
\text { Increase } \\
(\%)\end{array}$} & \multirow{2}{*}{$\begin{array}{c}\text { Avg } \\
\text { Strength } \\
\text { increase per } \\
\text { layer }(\%)\end{array}$} & \multirow{2}{*}{$\begin{array}{l}\text { Strength } \\
\text { Increase }\end{array}$} \\
\hline & (lbs) & (psi) & (psi) & & & & \\
\hline \multirow{3}{*}{1} & 146500 & 5181 & \multirow{3}{*}{5075} & 25.8 & \multirow{3}{*}{23.2} & \multirow{3}{*}{23} & \multirow{3}{*}{1.23} \\
\hline & 138000 & 4881 & & 18.5 & & & \\
\hline & 146000 & 5164 & & 25.3 & & & \\
\hline \multirow{3}{*}{2} & 212500 & 7516 & \multirow{3}{*}{7551} & 82.4 & \multirow{3}{*}{83} & \multirow{3}{*}{42} & \multirow{3}{*}{1.83} \\
\hline & 209500 & 7410 & & 79.8 & & & \\
\hline & 218500 & 7728 & & 87.6 & & & \\
\hline \multirow{3}{*}{3} & 280500 & 9921 & \multirow{3}{*}{8942} & 140.8 & \multirow{3}{*}{117} & \multirow{3}{*}{39} & \multirow{3}{*}{2.17} \\
\hline & 193000 & 6826 & & 65.7 & & & \\
\hline & 285000 & 10080 & & 144.6 & & & \\
\hline
\end{tabular}


Table 5.4: Compressive Strength of Wrapped Cylinders from Batch 2

\begin{tabular}{|c|c|c|c|c|c|c|c|}
\hline \multirow{2}{*}{$\begin{array}{c}\text { Descript } \\
\text { ion }\end{array}$} & $\begin{array}{c}\text { Axial } \\
\text { Strength }\end{array}$ & Stress & $\begin{array}{l}\text { Avg. } \\
\text { Stress } \\
\end{array}$ & \multirow{2}{*}{$\begin{array}{c}\text { Strength } \\
\text { Increase } \\
(\%)\end{array}$} & \multirow{2}{*}{$\begin{array}{c}\text { Avg. } \\
\text { Strength } \\
\text { Increase } \\
(\%)\end{array}$} & \multirow{2}{*}{$\begin{array}{c}\text { Avg } \\
\text { Strength } \\
\text { increase per } \\
\text { layer }(\%)\end{array}$} & \multirow{2}{*}{$\begin{array}{l}\text { Strength } \\
\text { Increase }\end{array}$} \\
\hline & (lbs) & (psi) & (psi) & & & & \\
\hline \multirow{3}{*}{1} & 197000 & 6967 & \multirow{3}{*}{6956} & 10.1 & \multirow{3}{*}{9.9} & \multirow{3}{*}{10} & \multirow{3}{*}{1.1} \\
\hline & 198000 & 7003 & & 10.6 & & & \\
\hline & 195000 & 6897 & & 8.9 & & & \\
\hline \multirow{3}{*}{2} & 212500 & 7516 & \multirow{3}{*}{8046} & 18.7 & \multirow{3}{*}{27} & \multirow{3}{*}{14} & \multirow{3}{*}{1.27} \\
\hline & 239000 & 8453 & & 33.5 & & & \\
\hline & 231000 & 8170 & & 29.1 & & & \\
\hline \multirow{3}{*}{3} & 287000 & 10151 & \multirow{3}{*}{10133} & 60.3 & \multirow{3}{*}{60.1} & \multirow{3}{*}{20} & \multirow{3}{*}{1.6} \\
\hline & 283000 & 10009 & & 58.1 & & & \\
\hline & 289500 & 10239 & & 61.7 & & & \\
\hline
\end{tabular}

> The average increase in strength for wrapped concrete cylinders from Batch 1 with 1, 2 and 3 layers is determined to be $23 \%, 42 \%$, and $39 \%$, respectively.

$>$ The average increase in strength for wrapped concrete cylinders from Batch 2 with 1, 2 and 3 layers is determined to be $10 \%, 14 \%$, and $20 \%$, respectively.

\subsubsection{Failure Mode}

Figures 5.17 to Figure 5.21 show failure modes of concrete cylinders in compression with and without BFRP wraps (1, 2, and 3 layers).

- Plain concrete cylinders without any wrapping exhibited brittle failure. (Figure 5.16)

- Specimens with 1,2 and 3 layered wrap failed after the failure initiation in the wrap at the mid height as shown in Figures 5.17-5.19 

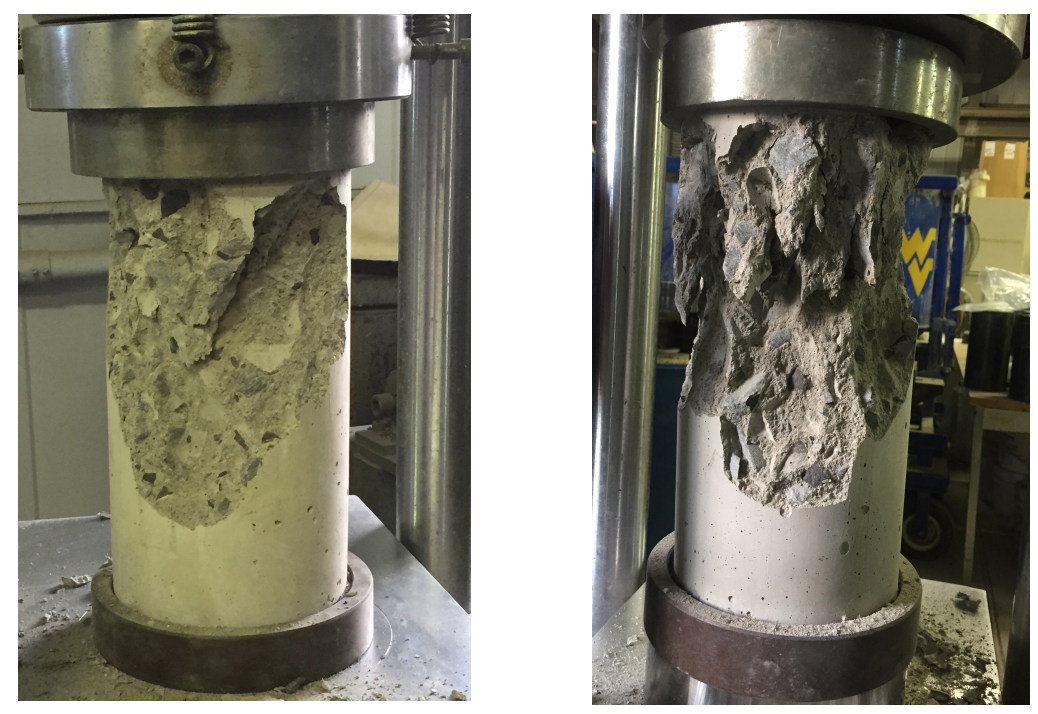

Figure 5.16: Plain Concrete Specimens under Compression Test Batch1 (Left), Batch2 (Right)
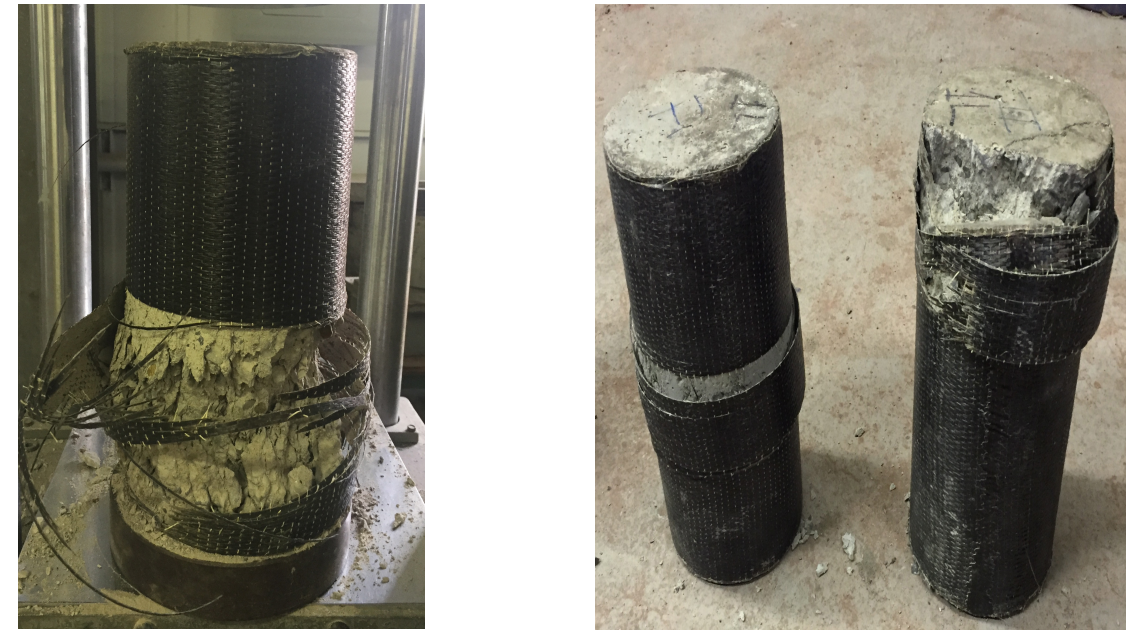

Figure 5.17: 1 Layer BFRP Concrete Cylinder Specimens Under Compression Test Batch1 (Left), Batch2 (Right) 

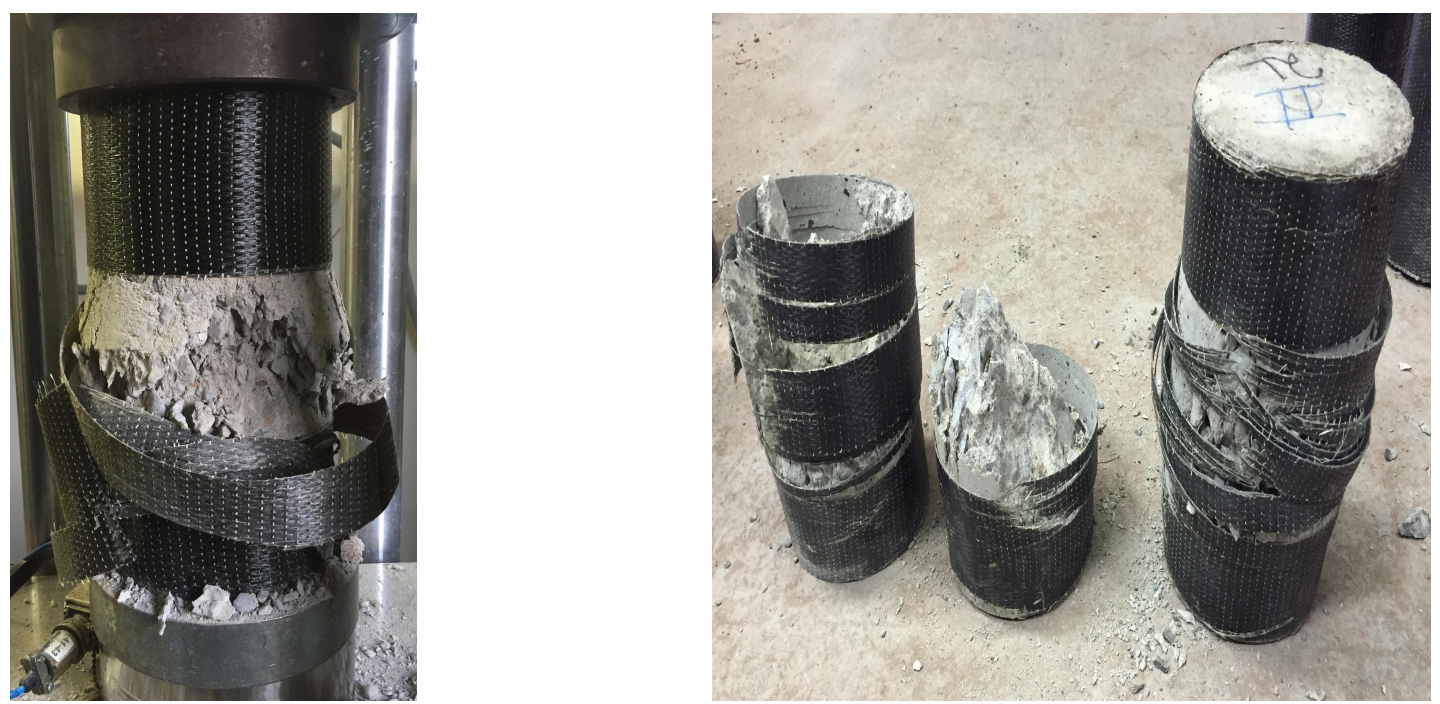

Figure 5.18: 2 Layer BFRP Concrete Cylinder Specimens Under Compression Test Batch1 (Left), Batch2 (Right)

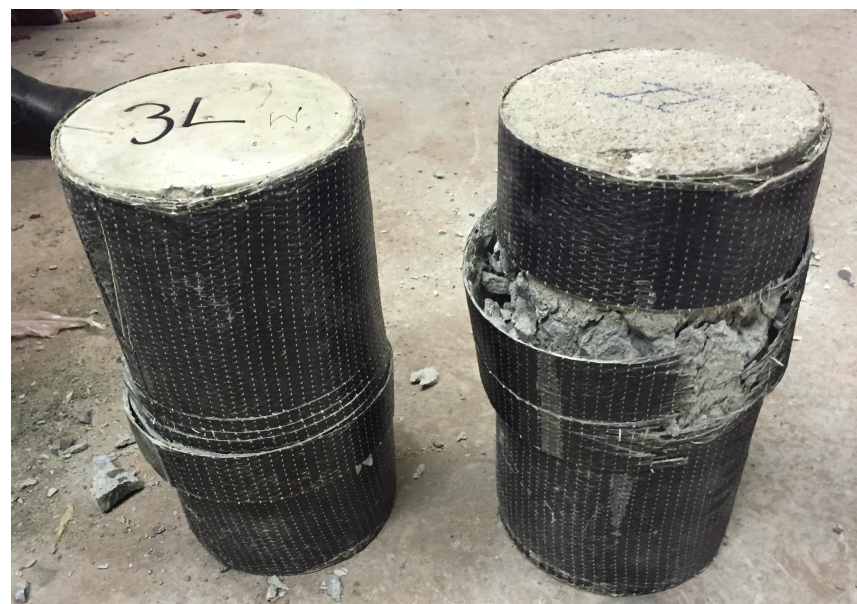

Figure 5.19: 3 Layer BFRP Concrete Cylinder Specimens Under Compression Test Batch1 (Left), Batch2 (Right)

\subsubsection{Basalt FRP Coupon Tension Test}

Basalt FRP coupon specimens were tested in 1, 2, 3, and 5 layers in tension. Table 5.5 shows a summary of the test results. Stiffness of the basalt FRP fabric varies between 4.16-5.1 Msi. 
Table 5.5: Summarized Stress and Stiffness Values

\begin{tabular}{|c|c|c|c|c|}
\hline \multirow{2}{*}{$\begin{array}{c}\text { No. of } \\
\text { Layers }\end{array}$} & Load Capacity & Tensile Stress & Strain & Stiffness \\
\cline { 2 - 5 } & $(\mathrm{lbs})$ & $(\mathrm{ksi})$ & $(\%)$ & $(\mathrm{Msi})$ \\
\hline 1 & $764^{*}$ & $48508^{*}$ & 2.105 & 4.66 \\
\hline 2 & 2323 & 77433 & 2.003 & 5.1 \\
\hline 3 & 3384 & 76475 & 2.603 & 4.53 \\
\hline 5 & 5366 & 78623 & 2.114 & 4.16 \\
\hline
\end{tabular}

*Results of 1 layer fabric indicated lower stress values and will not be used (outlier)

Tensile stress is calculated as $\boldsymbol{\sigma}=\frac{\operatorname{Load}(\boldsymbol{P})}{\operatorname{Area}}$, where area is calculated as width times thickness of tabs. Thickness of 1, 2, 3, and 5 layers of BFRP fabric are 0.015", 0.04”, 0.06" and $0.092 "$, respectively.

\subsection{Analytical Evaluation}

An example of analytical evaluation using various models proposed below with the strength of control specimens by different researcher.

\section{Strength of Plain Concrete Cylinder}

Batch 1:

$f_{c}^{\prime}=4210 \mathrm{psi}$

Area of cylinder $=\pi(3)^{2}=28.27 \mathrm{in}^{2}$

Strength of cylinder $=$ Compressive strength $\mathrm{x}$ Area of cylinder

$$
=4210 \text { x } 28.27=119034.95 \mathrm{lbs} \sim \mathbf{1 1 9 . 0 4} \text { kips }
$$

\section{Batch 2:}

$f_{c}^{\prime}=6331 \mathrm{psi}$

Area of cylinder $=\pi(3)^{2}=28.27 \mathrm{in}^{2}$

Strength of cylinder $=$ Compressive strength $\mathrm{x}$ Area of cylinder 


$$
=6331 \mathrm{x} 28.27=187487.11 \mathrm{lbs} \sim \mathbf{1 8 7 . 4 9} \text { kips }
$$

\section{Analytical calculations were done using existing models from other researchers}

Several of the analyses follow the procedure reported by ACI Committee 440. In this work, ACI 440 model is used to calculate the confined compressive strength of circular concrete cylinders, with FRP wrapping. (440.2R-08, 2008).

$$
\frac{f_{c c}^{\prime}}{f_{c o}^{\prime}}=1+3.3 \frac{f_{l}}{f_{c o}^{\prime}}
$$

Where,

$f_{c c}^{\prime}=$ Compressive strength of confined concrete

$f_{c o}^{\prime}=$ Compressive strength of unconfined concrete

$f_{l}=$ Lateral confined pressure by BFRP wraps, calculated using Eq. (5.2)

$$
f_{l}=\frac{2 E_{f} n t_{f} \epsilon_{f e}}{D}
$$

Where,

$E_{f}=$ Modulus of elasticity of BFRP $=4.5 \mathrm{msi}$

$n=$ Number of layers; 1,2 , and 3

$t_{f}=$ Thickness of BFRP fabric $=0.0156^{\prime \prime}$

$\epsilon_{f e}=$ Effective failure strain of fabric, calculated using Eq. (5.3)

$\epsilon_{f e}=k_{\epsilon} \epsilon_{f u}$

Where,

$$
k_{\epsilon}=\text { Strain efficiency factor }=0.55
$$


$\epsilon_{f u}=$ Ultimate failure strain of fabric $=26033$

\section{Batch I}

Table 5.6: Batch I Comparison of Experimental Results and Theoretical Results of Confined Strength of Concrete

\begin{tabular}{|c|c|c|c|c|c|}
\hline \multirow[t]{2}{*}{$\begin{array}{l}\text { No. of } \\
\text { layers }\end{array}$} & $\begin{array}{l}\text { Unconfined } \\
\text { concrete } \\
\text { strength } \\
\left(f_{c o}^{\prime}\right)\end{array}$ & $\begin{array}{l}\text { Lateral wrap } \\
\text { confinement } \\
\text { pressure }\left(f_{l}\right)\end{array}$ & $\begin{array}{c}\text { Experimental } \\
\text { confined strength } \\
\text { of concrete }\left(f_{c c}^{\prime}\right) \\
\text { exptl }\end{array}$ & $\begin{array}{c}\text { Theoretical confined } \\
\text { strength of concrete } \\
\quad\left(f_{c c}^{\prime}\right) \text { therory }\end{array}$ & \multirow[t]{2}{*}{$\frac{\left(f_{c c}^{\prime}\right) \text { exptl }}{\left(f_{c c}^{\prime}\right) \text { theory }}$} \\
\hline & psi & psi & psi & psi & \\
\hline 1 & \multirow{3}{*}{4120} & 322 & 5075 & 5183 & 0.98 \\
\hline 2 & & 644 & 7551 & 6247 & 1.21 \\
\hline 3 & & 966 & 8942 & 7310 & 1.22 \\
\hline
\end{tabular}

\section{Batch II}

Table 5.7: Batch II Comparison of Experimental Results and Theoretical Results of Confined Strength of Concrete

\begin{tabular}{|c|c|c|c|c|c|}
\hline $\begin{array}{l}\text { No. } \\
\text { of } \\
\text { layer }\end{array}$ & $\begin{array}{l}\text { Unconfined } \\
\text { concrete } \\
\text { strength } \\
\left(f_{c o}^{\prime}\right) \\
\end{array}$ & $\begin{array}{l}\text { Lateral wrap } \\
\text { confinement } \\
\text { pressure }\left(f_{l}\right)\end{array}$ & $\begin{array}{c}\text { Experimental } \\
\text { confined strength } \\
\text { of concrete }\left(f_{c c}^{\prime}\right) \\
\text { exptl }\end{array}$ & $\begin{array}{l}\text { Theoretical confined } \\
\text { strength of concrete } \\
\qquad\left(f_{c c}^{\prime}\right) \text { theory }\end{array}$ & $\frac{\left(f_{c c}^{\prime}\right) \text { exptl }}{\left(f_{c c}^{\prime}\right) \text { theory }}$ \\
\hline & psi & psi & psi & psi & \\
\hline 1 & \multirow{3}{*}{6331} & 322 & 6956 & 7394 & 0.94 \\
\hline 2 & & 644 & 8046 & 8457 & 0.95 \\
\hline 3 & & 966 & 10133 & 9520 & 1.06 \\
\hline
\end{tabular}

Tables 5.6 and 5.7 show the calculated values of the analytical confined strength for batch I $f_{c}^{\prime}=$ $4210 \mathrm{psi})$ and batch II $\left(f_{c}^{\prime}=6331 \mathrm{psi}\right)$, respectively. Experimental to analytical values of confined strength are greater than 1 and reflect a theoretical under prediction. Ratios smaller than 
1 reflect a theoretical over prediction. From Tables 5.6 and 5.7, it can be concluded that the experimental values were as much as $22 \%$ higher than theoretical values.

\subsection{Summary}

- Concrete cylinders were tested with external BFRP fabric wrapping to study the effect of confinement with respect to number of wraps and cylinder strength.

- Strength of wrapped concrete cylinders due to wrapping increased by 2.22 times of that without wrap (4120 psi vs., 8942 psi).

- Basalt fabric wrapping is a very effective technique in increasing the confinement-related strength of axial members as shown in this study. 


\section{Conclusions}

Conclusions on the application of basalt FRP (BFRP) for reinforcing concrete beams and columns in the form of bars and wraps have been investigated in this study.

\subsection{Basalt FRP Bars}

Basalt FRP bars were tested to determine their mechanical and physical properties.

\subsubsection{Tension Tests}

Tension tests were conducted to determine ultimate strength and stiffness of the BFRP bar using load cell, strain gage data, and data acquisition system.

Table 6.1: Tensile Strength and Stiffness of Basalt FRP Bars

\begin{tabular}{|c|c|c|c|}
\hline \multirow{2}{*}{ Bar Size } & Diameter & Stress & Stiffness \\
\cline { 2 - 4 } & $($ in $)$ & $(\mathrm{ksi})$ & $(\mathrm{Msi})$ \\
\hline$\# 4$ & 0.500 & 118.57 & 8.670 \\
\hline$\# 5$ & 0.625 & 106.69 & 6.735 \\
\hline
\end{tabular}

- Stress and Stiffness: As shown from the results, \#4 diameter bars have an average stress of $11.14 \%$ more than \#5 diameter bars, which is because of the shear lag in larger diameter bars. The average stiffness of \#4 diameter bars is $28.73 \%$ more than \#5 diameter bars. 
- Failure mode: Failure mode in all the bars was observed at the middle of the bar with fibers splitting in the outer layer. At the end of the test, fibers were split into conical mesh pattern (Figure 3.2).

\subsubsection{Compression Tests}

Compression tests were conducted to determine ultimate strength and stiffness of the BFRP bar using data from load cell, strain gage data, and data acquisition system.

Table 6.2: Compressive Strength and Stiffness of Basalt FRP Bars

\begin{tabular}{|c|c|c|c|}
\hline \multirow{2}{*}{ Bar Size } & Diameter & Stress & Stiffness \\
\cline { 2 - 4 } & $($ in $)$ & $(\mathrm{ksi})$ & $(\mathrm{Msi})$ \\
\hline$\# 4$ & 0.500 & 62.24 & 7.33 \\
\hline$\# 5$ & 0.625 & 69.50 & 6.87 \\
\hline
\end{tabular}

- Stress and Stiffness: The average compressive stress of \#4 and \#5 BFRP bars are 30$40 \%$ less than the average tensile stress. The average stiffness of \#4 BFRP bar is $8.28 \mathrm{ksi}$ and that of \#5 BFRP bar is $8.74 \mathrm{ksi}$.

- Failure Mode: Failure mode in all specimens was by buckling of fibers and separation of fibers from resin.

\subsubsection{Shear Tests}

Single and double shear tests were to determine the ultimate shear strength of BFRP bars. 


\section{Table 6.3: Single and Double Shear Strength of Basalt FRP Bars}

\begin{tabular}{|c|c|c|c|}
\hline \multirow{2}{*}{ Bar Size } & Diameter & Single Shear & Double Shear \\
\cline { 2 - 4 } & $($ in $)$ & $(\mathrm{ksi})$ & $(\mathrm{ksi})$ \\
\hline$\# 4$ & 0.500 & 26.12 & 29.57 \\
\hline$\# 5$ & 0.625 & 23.96 & 27.95 \\
\hline
\end{tabular}

- Failure Mode: All of the BFRP bar specimens failed at the shear edge of the cutting tool during single and double shear tests.

- Shear stress from single shear test are $10-12 \%$ less than double shear tests due to the effect of bending in single shear test. It should be noted that the single shear specimens are supported as cantilever specimens during testing.

\subsubsection{Inter-Laminar Shear Tests}

This test was done to determine the inter-laminar shear strength of basalt FRP bar. The bars with \#4 diameters showed slightly larger inter-laminar shear than \#5 bars (7.25- $7.40 \mathrm{ksi})$

Table 6.4: Inter-Laminar Shear Strength of Basalt FRP Bars

\begin{tabular}{|c|c|c|}
\hline \multirow{2}{*}{ Bar Size } & Diameter & Inter-Laminar Shear \\
\cline { 2 - 3 } & (in) & $(\mathrm{ksi})$ \\
\hline$\# 4$ & 0.500 & 7.40 \\
\hline$\# 5$ & 0.625 & 7.25 \\
\hline
\end{tabular}

- Failure Mode: All BFRP bar specimens were permanently deformed at the at the location of load application (mid-section) and fiber failure was noticed. 


\subsubsection{Burn-off Test}

Fiber volume fraction test is performed to determine the volume and mass content of resin and fiber in a composite. Fiber volume fraction of the bar is determined from the resin burn-off test as per ASTM D 2584-68. Fiber volume fraction of the epoxy BFRP is $71.68 \%$ for $\# 4$ bar and $67.96 \%$ for \#5 bar, which indicates the right amount of fabrics to be used as reinforcement in a composite reinforcing bar for concrete members.

\subsubsection{Differential Scanning Calorimeter (DSC) Test}

DSC test was carried out to determine the glass transition temperature of basalt FRP bars. Glass transition temperature $\left(\mathrm{T}_{\mathrm{g}}\right)$ of BFRP bar with uniform curing was found to be $109^{\circ} \mathrm{C}$.

\subsubsection{Moisture Absorption Test}

This test is done to determine the percentage of moisture gain in basalt FRP bars when it is immersed in water for 360 hours. Maximum Moisture absorption in \#4 and \#5 sand coated BFRP bars is $0.24 \%$.

\subsection{Behavior of Beams with External and Internal Basalt FRP}

BFRP wrapped beams showed significant increase in strength as compared to base beam without wrapping. Maximum increase in beams' load and bending moment due to 2 and 3 layers of BFRP wrap is $58 \%$ and $71 \%$, respectively. Deflection and crack-widths were noted to decrease with the bonding of additional FRP fabrics.

Beams were tested with both \#4 and \#5 internal FRP bars and external FRP fabrics ( 1 and 
2 layers) in the tension zone. Beams with larger diameter bars carried higher failure loads as compared to those with smaller diameter bars (\#4) for similar number of FRP fabrics (1 or 2 layers). Increasing the number of FRP fabrics resulted in corresponding strength and stiffness increase. Increase in beam stiffness due to bonding of BFRP fabrics resulted in a reduction of deflection and crack-width at a given load.

From the test results, it is evident that BFRPs can be an effective alternative reinforcement for concrete beams of steel bars and glass FRP bars or fabrics.

\subsection{Basalt FRP Wrap of Concrete Cylinder}

- Concrete cylinders were tested with external BFRP fabric wrapping to study the effect of confinement with respect to number of wraps and cylinder strength.

- Strength of wrapped concrete cylinders due to wrapping increased by 2.22 times as compared to those without wraps (4120 psi vs. $8942 \mathrm{psi})$.

- Basalt fabric wrapping is a very effective tool in increasing the confinement-related strength of axial members as shown in this study.

\subsection{Future Recommendations}

Additional testing with more parameters such as varying BFRP reinforcement ratio; resin and primer types, concrete compressive strength, and beam dimensions are recommended. Durability study of BFRP bars and fabrics is also necessary for their field implantation and development of related code specifications. 


\section{References}

440.2R-08, A. (2008). Guide for the Design and Construction of Externally Bonded FRP Systems for Strengthening Concrete Structures. ACI Committee 440.

Abdelrahman, K., \& Raafat, E.-H. (2014). Cost and Ductility Effectiveness of Concrete Columns Strengthened with CFRP and SFRP Sheets. polymers .

(1997). ACI. Performance characteristics and Application of High-Performance Polyo1efin Fiber Reinforced Concretes. American Concrete Institute.

Banibayat, P. (2011). EXPERIMENTAL INVESTIGATION OF THE MECHANICAL AND CREEP RUPTURE PROPERTIES OF BASALT FIBER REINFORCED POLYMER (BFRP) BARS.

Basalt. (2016). Retrieved from http://www.sandatlas.org.

Basalt fiber comparing with the other fibers. (n.d.). (Pulwell composite Co., Ltd.) Retrieved from http://www.pulwellfrp.com/en/Products.aspx?id=275

Basalt Rebar Manufacturer . (2015). Retrieved from http://fiberglassrebar.us/basaltrebar/

Benzaid, R., \& Mesbah, H.-A. (2013). In Circular and Square Concrete Columns Externally Confined by CFRP Composite: Experimental Investigation and Effective Strength Models.

Binertury, C., Hilaire, B., \& Pabiot, J. (1997). The interactions between flows occurring inside and outside fabric tows during RTM. In Composites Science and Technology (pp. 587596).

Brik, V. B. (1997). BASALT FIBER COMPOSITE REINFORCEMENT FOR CONCRETE. Transportation Research Board National Research Council, Wisconsin.

Caiyun, Y., \& Fengjing , L. (2010). Experimental study on the acid \& alkali resistance of basalt fiber fabric. Tianjin Polytechnic University.

Deficient Bridges by State and Highway System. (2014). Retrieved from https://www.fhwa.dot.gov.

Differential Scanning Calorimeter ASTM D3418, ASTM E1356, ISO 11357.

Fiore, V., Scalici, T., Di Bella, G., \& Valenza, A. (2015). A review on basalt fibre and its composites.

Grieken, A. (2009). Deficiencies in concrete structures 'The Sherlock Holmes' factor. Melbourne. 
Irine, F. (2013). Strength Aspects of Basalt Fiber Reinforced Concrete. M.G University, Kerala.

Kumbhar, V. P. (2014). An Overview: Basalt Rock Fibers - New Construction Material. AGTI's Dr. Daulatrao Aher College of Engineering, Karad.

Parnas, D. R., Shaw, D. M., \& Liu, Q. (2007). Basalt Fiber Reinforced Polymer Composites. Parvin, A., \& Brighton , D. (2014, APRIL). FRP Composites Strengthening of Concrete Columns under Various Loading Conditions .

Patnaik, A. (2009). Applications of Basalt Fiber Reinforced Polymer (BFRP) Reinforcement for Transportation Infrastructure. Department of Civil Engineering. Akron: The University of Akron.

Pawłowskia, D., \& Szumigała, M. (2015). Flexural behaviour of full-scale basalt FRP RC beams - experimental and numerical studies. Poznan University of Technology, Faculty of Civil and Environmental Engineering, Poznań.

Rajappa, R. (2004). BEHAVIOR OF FRP WRAPPED CONCRETE CYLINDERS. West Virginia University.

Ramakrishnnan, V. (1993). Recent Advancements in Concrete Fiber Composites.

Ross, A. (2006). Basalt Fibers: Alternative To Glass?

Smarter Building Systems. (2015, November 29). Retrieved from http://smarter-buildingsystems.com

Sveinsdóttir , L. S. (2012). Experimental research on strengthening of concrete beams by the use of epoxy adhesive and cement-based bonding material.

Thorhallsson, E., Kubens , S., \& Konradsson , A. (2011). Concrete Cylinders Confined with Basalt Fibre Reinforced Polymer. Reykjavik University.

University of Miami . (2016). EVALUATION of RockRebarTM per ICC-ES Acceptance Criteria 454 and FDOT Section 932-3, Fiber Reinforced Polymer (FRP) Reinforcing Bars. University of Miami, College of Engineering Structures and Materials Laboratory . 


\section{Appendix A: Deflection and Crack-Width}

\section{Strain Values and Theoretical Calculations}

From different beams, the strain values in BFRP bars were noted to be up to $2.9 \%$ and in the FRP fabrics the values were up to $1.1 \%$. Some of the strain gages didn't function during final loading stages. Deflection calculation and comparison with experimental values are provided at regular internals in the following two examples. Similarly, crack-width calculations are also shown. Simplified methods have been used and development of better deflection and crack-width prediction models will require additional research work.

\section{Deflection Calculation Example \#1:}

- Deflection of \#4 BFRP beam with 2 layers basalt fiber wrap is calculated below:

\section{Dimension:}

$b=6$ inch

$\mathrm{h}=15$ inch

$\mathrm{d}=12.25$ inch

$d "=1.75 "$

\section{Reinforcement:}

Compression $=2 \# 5$ and $1 \# 4$ steel bars

Tension $=2 \# 4$ BFRP bars

Given:

$$
\begin{aligned}
& f_{c}^{\prime}=4.5 \mathrm{ksi} \\
& f_{y}=60 \mathrm{ksi} \\
& \beta_{1}=0.825
\end{aligned}
$$




$$
\begin{aligned}
& E_{f r p}=8 \mathrm{Msi}=8000 \mathrm{ksi} \\
& E_{\text {steel }}=29 \mathrm{Msi} \\
& A \# 4=0.20 \mathrm{in}^{2} \\
& A \# 5=0.31 \mathrm{in}^{2}
\end{aligned}
$$

\section{Solution:}

\section{Find cracking moment:}

$f_{r}=7.5 \sqrt{f_{c}^{\prime}}=7.5 \sqrt{4500}=503 \mathrm{psi}$

$M_{c r}=\frac{2 f_{r} I_{g}}{12}=2 \times 504 \times \frac{1687.5}{12000}=9.43 \mathrm{k}-\mathrm{ft}$.

Note: For simplicity and ease of use, neutral axis factor is calculated separately for reinforcing bars and fabrics and added later.

\section{FRP bar neutral axis factor:}

$$
\begin{aligned}
& n_{f}(\text { bar })=\frac{E_{f r p}}{E_{c}}=8 \mathrm{Msi} /(57,000 \sqrt{4500}) \mathrm{psi}=2.1 \\
& A_{f}(\text { bar })=0.2 \times 2=0.40 \mathrm{inch}^{2} \\
& \rho_{f}(\text { bar })=\frac{A_{f}}{b d}=\frac{0.40}{6} \times 12.25=0.00544 \\
& A_{f} n_{f}(\text { bar })=0.40 \times 2.1=0.8 \\
& \rho_{f} n_{f}(\text { bar })=0.00544 \times 2.1=0.01139 \\
& k_{1}(\text { bar })=\sqrt{\left(\rho_{f} n_{f}\right)^{2}+2 \rho_{f} n_{f}}-\rho_{f} n_{f}=0.13995 .
\end{aligned}
$$


FRP fabric neutral axis factor (Simplified method):

$n_{f}($ fabric $)=\frac{E_{f r p}}{E_{c}}=24 \mathrm{Msi} /(57,000 \sqrt{4500}) \mathrm{psi}=0.6$

$A_{f}($ fabric $)=n \times$ width $\times$ thickness $=2 \times 6 \times 0.013=0.156$ inch $^{2}$

$\rho_{f}($ fabric $)=\frac{A_{f}}{b d}=\frac{0.156}{6} \times 12.25=0.00212$

$A_{f} n_{f}($ bar $)=0.156 \times 0.6=0.1$

$\rho_{f} n_{f}($ bar $)=0.00212 \times 0.6=0.00133$

$k_{2}($ fabric $)=\sqrt{\left(\rho_{f} n_{f}\right)^{2}+2 \rho_{f} n_{f}}-\rho_{f} n_{f}=0.0558$

FRP neutral axis factor:

$k=k_{1}($ bar $)+k_{2}($ fabric $)$

$k=0.13995+0.05580=0.19575$

Find moment of inertia of the gross section:

$I_{g}=\frac{b h^{3}}{12}=6 \times \frac{15^{3}}{12}=1687.5 i n^{4}$

Find moment of inertia of the cracked section:

$I_{c r}=\frac{b d^{3}}{3} k^{3}+n_{f r p} A_{f r p}(d)^{2}(1-k)^{2}$

$=\frac{6 \times 12.25^{3}}{3} 0.13995^{3}+(0.1+0.8) 12.25^{2}\left(1-0.13995^{3}\right)$

$=113.84 \mathrm{in}^{4}$ 
Find $\beta_{d}$ from ACI 440:

$\beta_{d}=\alpha_{d}\left(\frac{E_{\text {frp }}}{E_{\text {steel }}}+1\right)$, where $\alpha_{d}=0.5$

$=0.5\left(\frac{2.4}{29}+1\right)=0.54$

Find Effective moment of inertia of the cracked section:

$\left(I_{e}\right)_{D+L}=\left(\frac{M_{c r}}{M_{a}}\right)^{3} \beta_{d} I_{g}+\left[1-\left(\frac{M_{c r}}{M_{a}}\right)^{3}\right] I_{c r} \leq I_{g}$

\section{Experimental and theoretical calculation of $6 \mathrm{ft}$ BFRP Beam}

Table A.1: \#4 BFRP Beam Bonded with 2 Layers of BFRP fabric

\begin{tabular}{|c|c|c|c|c|c|c|}
\hline Live Load & Ma & $\begin{array}{c}\text { (Mcr/Ma)^ } \\
3\end{array}$ & $\begin{array}{c}\text { le } \\
\text { def_theor. }\end{array}$ & $\begin{array}{c}\text { def(expt//the } \\
\text { o) }\end{array}$ \\
\hline (kips) & (kip.ft) & & (in^4) & (in) & (in) & \\
\hline 0 & 0 & 0 & 0 & 0 & 0 & 0 \\
\hline 10 & 12.5 & 0.4298 & 457.575 & 0.0257 & 0.0502 & 1.95 \\
\hline 20 & 25 & 0.0537 & 156.807 & 0.1501 & 0.1764 & 1.18 \\
\hline 30 & 37.5 & 0.0159 & 126.571 & 0.2789 & 0.2922 & 1.05 \\
\hline 36 & 45 & 0.2096 & 121.208 & 0.3495 & 0.3193 & 0.91 \\
\hline
\end{tabular}

Note: As per the above table, the ratio of experimental to theoretical deflection values at discrete data points is ranging from 0.91 to 1.95 and needs to be studied further for additional refinement. 


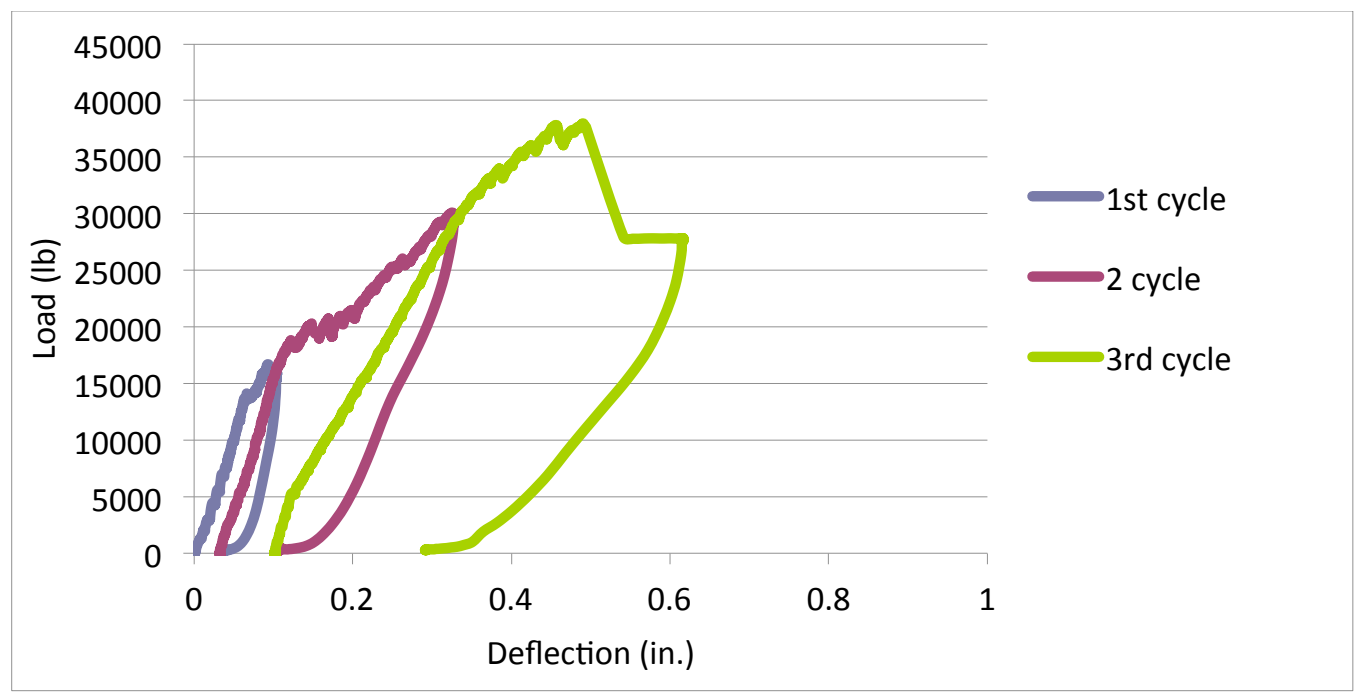

Figure A.1: Load-Deflection Diagram of \#4 BFRP Beam Bonded with 2 Layers of BFRP Wrap

\section{Deflection Calculation Example \#2:}

- Deflection of \#5 BFRP beam with 1 layer basalt fiber wrap calculated below:

\section{Dimension:}

$b=6$ inch

$\mathrm{h}=15$ inch

$\mathrm{d}=12.25$ inch

$\mathrm{d} "=2.75 "$

\section{Reinforcement:}

Compression $=2 \# 5$ and $1 \# 4$ steel bars

Tension $=2 \# 4$ BFRP bars

\section{Given:}

$$
\begin{aligned}
& f_{c}^{\prime}=4.5 \mathrm{ksi} \\
& f_{y}=60 \mathrm{ksi}
\end{aligned}
$$




$$
\begin{aligned}
& \beta_{1}=0.825 \\
& E_{\text {frp }}=8 \mathrm{Msi}=8000 \mathrm{ksi} \\
& E_{\text {steel }}=29 \mathrm{Msi} \\
& A \# 4=0.20 \mathrm{in}^{2} \\
& A \# 5=0.31 \mathrm{in}^{2}
\end{aligned}
$$

\section{Solution:}

\section{Find cracking moment:}

$$
\begin{aligned}
& f_{r}=7.5 \sqrt{f_{c}^{\prime}}=7.5 \sqrt{4500}=503 \mathrm{psi} \ldots \ldots \ldots \\
& M_{c r}=\frac{2 f_{r} I_{g}}{12}=2 \times 504 \times \frac{1687.5}{12000}=9.43 \mathrm{k}-\mathrm{ft} .
\end{aligned}
$$

Note: For simplicity and ease of use, neutral axis factor is calculated separately for reinforcing bars and fabrics and added later.

\section{FRP bar neutral axis factor:}

$$
\begin{aligned}
& n_{f}(\text { bar })=\frac{E_{f r p}}{E_{c}}=8 \mathrm{Msi} /(57,000 \sqrt{4500}) \mathrm{psi}=2.1 \\
& A_{f}(\text { bar })=0.31 \times 2=0.62 \mathrm{inch}^{2} \\
& \rho_{f}(\text { bar })=\frac{A_{f}}{b d}=\frac{0.62}{6} \times 12.25=0.00843 \\
& A_{f} n_{f}(\text { bar })=0.62 \times 2.1=1.30 \\
& \rho_{f} n_{f}(\text { bar })=0.00544 \times 2.1=0.0177 \\
& k_{1}(\text { bar })=\sqrt{\left(\rho_{f} n_{f}\right)^{2}+2 \rho_{f} n_{f}}-\rho_{f} n_{f}=0.17105 .
\end{aligned}
$$


FRP fabric neutral axis factor (Simplified method):

$n_{f}($ fabric $)=\frac{E_{f r p}}{E_{c}}=24 \mathrm{Msi} /(57,000 \sqrt{4500}) \mathrm{psi}=0.6$

$A_{f}($ fabric $)=n \times$ width $\times$ thickness $=1 \times 6 \times 0.013=0.078 \mathrm{inch}^{2}$

$\rho_{f}($ fabric $)=\frac{A_{f}}{b d}=\frac{0.078}{6} \times 12.25=0.00106$

$A_{f} n_{f}($ bar $)=0.078 \times 0.6=0.04896$

$\rho_{f} n_{f}($ bar $)=0.00106 \times 0.6=0.00067$

$k_{2}($ fabric $)=\sqrt{\left(\rho_{f} n_{f}\right)^{2}+2 \rho_{f} n_{f}}-\rho_{f} n_{f}=0.03973$

FRP neutral axis factor:

$k=k_{1}($ bar $)+k_{2}($ fabric $)$

$k=0.17105+0.03973=0.21078$

Find moment of inertia of the gross section:

$I_{g}=\frac{b h^{3}}{12}=6 \times \frac{15^{3}}{12}=1687.5 i n^{4}$

Find moment of inertia of the cracked section:

$I_{c r}=\frac{b d^{3}}{3} k^{3}+n_{f r p} A_{f r p}(d)^{2}(1-k)^{2}$.

$=\frac{6 \times 12.25^{3}}{3} 0.21078^{3}+(01.30+0.0490) 12.25^{2}\left(1-0.21078^{3}\right)$

$=160.25 \mathrm{in}^{4}$ 
Find $\beta_{d}$ from ACI 440:

$\beta_{d}=\alpha_{d}\left(\frac{E_{f r p}}{E_{\text {steel }}}+1\right)$, where $\alpha_{d}=0.5$.

$=0.5\left(\frac{2.4}{29}+1\right)=0.54$

Find Effective moment of inertia of the cracked section:

$\left(I_{e}\right)_{D+L}=\left(\frac{M_{c r}}{M_{a}}\right)^{3} \beta_{d} I_{g}+\left[1-\left(\frac{M_{c r}}{M_{a}}\right)^{3}\right] I_{c r} \leq I_{g}$

Experimental and theoretical calculation of $6 \mathrm{ft}$ BFRP Beam

Table A.2: \#5 BFRP Beam Bonded with 1 Layer of BFRP fabric

\begin{tabular}{|c|c|c|c|c|c|c|}
\hline Live Load & Ma & $\begin{array}{c}(\mathrm{Mcr} / \mathrm{Ma})^{\wedge} \\
3\end{array}$ & le & def_theor. & def_exptl & $\begin{array}{l}\operatorname{def}(\text { explt/the } \\
\text { o) }\end{array}$ \\
\hline (kips) & (kip.ft) & & $($ in^4) & (in) & (in) & \\
\hline 0 & 0 & 0 & 0 & 0 & 0 & 0 \\
\hline 10 & 12.5 & 0.4298 & 482.3036 & 0.0244 & 0.0329 & 1.35 \\
\hline 20 & 25 & 0.0537 & 197.8457 & 0.1190 & 0.0756 & 0.67 \\
\hline 30 & 37.5 & 0.0159 & 169.2494 & 0.2086 & 0.1939 & 0.96 \\
\hline 40 & 50 & 0.0067 & 162.2885 & 0.2901 & 0.2959 & 1.04 \\
\hline 50 & 62.5 & 0.0034 & 159.8096 & 0.3682 & 0.4249 & 1.18 \\
\hline 60 & 75 & 0.0020 & 158.7139 & 0.4449 & 0.5109 & 1.17 \\
\hline 66 & 82.5 & 0.0015 & 158.3397 & 0.4906 & 0.6054 & 1.26 \\
\hline
\end{tabular}

Note: As per the above table, the ratio of experimental to theoretical deflection values at discrete data points is ranging from 0.67 to 1.53 and needs to be studied further for additional refinement. 


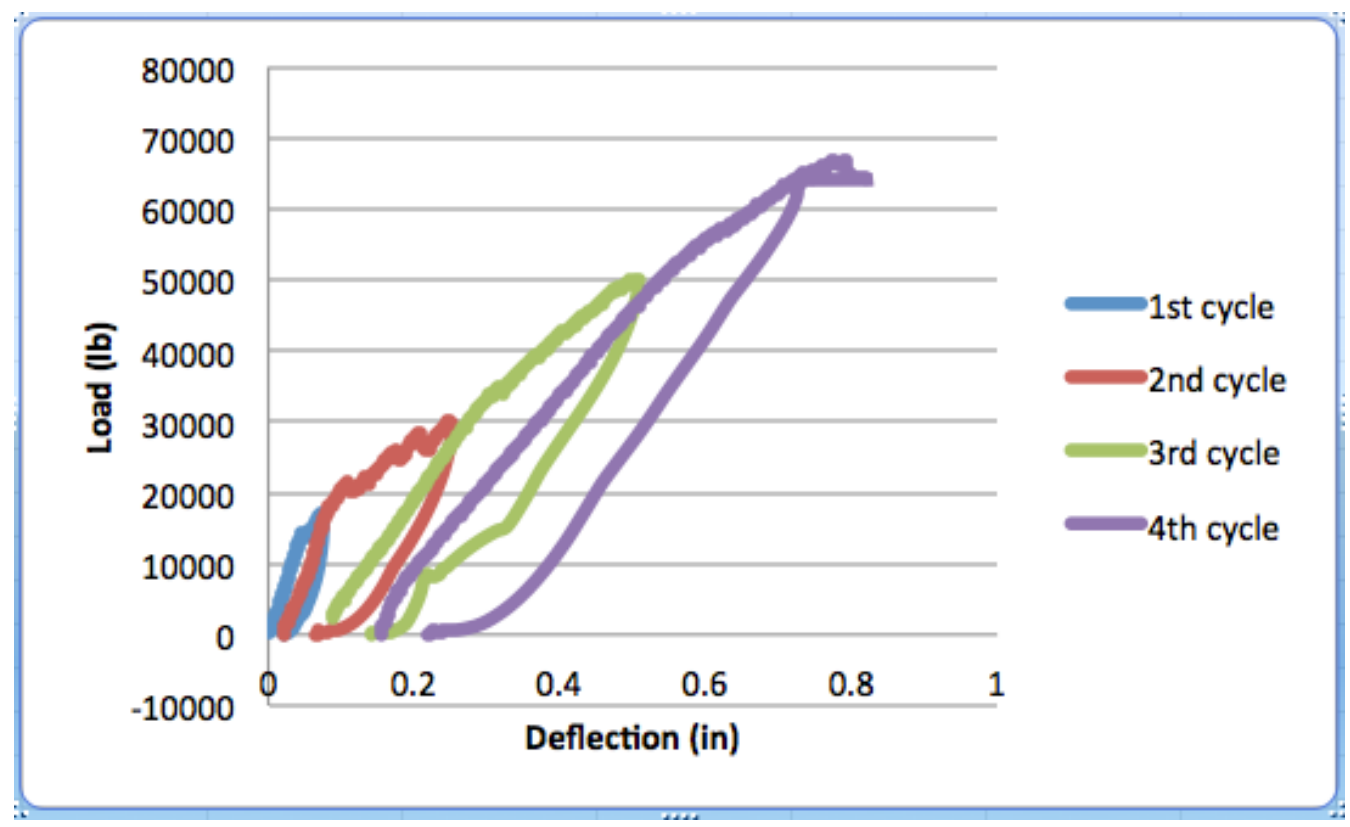

Figure A.2: Load-Deflection Diagram of \#4 BFRP Beam Bonded with 1 Layer of BFRP Wrap

Finding the crack-width of BFRP beam:

Crack-width of a beam is given by the following equations:

$w=\frac{2200}{E_{f}} \beta k_{b} f_{f} \sqrt[3]{d_{c} A}$

Where,

$\mathrm{w}=$ crack width

$\beta=$ The ratio of the distance from the neutral axis to the extreme tension fiber to the distance

from neutral axis to the centroid of tensile reinforcement

$\beta=\frac{h-k d}{d(1-k)}$ 
$d_{c}=$ The thickness of the concrete cover measured from the extreme tension fiber to the center of a bar or the closest wire location

$A=$ The effective tension area of concrete having the same centroid as that of tensile reinforcement, divided by the number of bars

$f_{f}=$ The stress in FRP reinforcement due to service loads

$E_{f}=$ The modulus of elasticity of FRP

$k_{b}=$ The corrective bond coefficient

Stress values can be calculated using the following equations in FRP bars and Fabrics.

$f_{f}=\frac{M_{s e r}}{A_{s} j d}$

In this example, crack-width for a stress value of $15 \mathrm{ksi}$ for BFRP bars is calculated as

follows:

Crack-width of \#4 BFRP beam with 1 layer of BFRP wrap is calculated below:

$A=\frac{\left(d^{\prime} \times 2 \times b\right)}{2}=\frac{1.75 \times 2 \times 6}{2}=10.5 \mathrm{in}^{2}$

$d_{c}=1.75$ inch

$k_{b}=1.2(\mathrm{ACI} 440)$

$\beta=\frac{15-1.75}{13.25-1.5}=1.12$ 
$E_{f}=8 \mathrm{Msi}$

$f_{f}=15 k s i$

$$
w=\frac{2200}{8000} 1.12 \times 1.2 \times 15 \times \sqrt[3]{1.75 \times 10.5}=14.63 \text { mils of inch }
$$

